\begin{abstract}
UNIVERSIDADE DE SÃO PAULO
ESCOLA DE COMUNICAÇÕES E ARTES

DEPARTAMENTO DE RELAÇÕES PÚBLICAS, PROPAGANDA E TURISMO PROGRAMA DE PÓS-GRADUAÇÃO EM CIÊNCIAS DA COMUNICAÇÃO
\end{abstract}

CAROLINA DE AVELLAR BARBOSA MORETTI

Comunicação e Cultura Organizacional: análise de um grupo de empresas sediadas no Brasil 


\section{Comunicação e Cultura Organizacional:} análise de um grupo de empresas sediadas no Brasil

Dissertação apresentada ao Programa de PósGraduação em Ciências da Comunicação (PPGCOM) da Escola de Comunicações e Artes da Universidade de São Paulo, como requisito para obtenção do titulo de Mestre em Ciências da Comunicação.

Área de Concentração: Interfaces Sociais da Comunicação

Linha de Pesquisa: Políticas e Estratégias da Comunicação

Orientadora: Prof. ${ }^{a}$ Dra. Maria Aparecida Ferrari

São Paulo 
Autorizo a reprodução e divulgação total ou parcial deste trabalho, por qualquer meio convencional ou eletrônico, para fins de estudo e pesquisa, desde que citada a fonte.

\section{Catalogação na Publicação \\ Serviço de Biblioteca e Documentação \\ Escola de Comunicações e Artes da Universidade de São Paulo \\ Dados fornecidos pelo(a) autor(a)}

Moretti, Carolina de Avellar Barbosa

Comunicação e Cultura Organizacional: Análise de um grupo de empresas sediadas no Brasil / Carolina de Avellar

Barbosa Moretti. -- São Paulo: C. A. B. Moretti, 2016.

$142 \mathrm{p}$.

Dissertação (Mestrado) - Programa de Pós-Graduação em

Ciências da Comunicação - Escola de Comunicaçōes e Artes / Universidade de São Paulo.

Orientadora: Maria Aparecida Ferrari

Bibliografia

1. comunicação 2. cultura organizacional 3. gestão brasileira 4. relaçōes públicas 5. empresas brasileiras I. Ferrari, Maria Aparecida II. Titulo.

CDD 21.ed. - 659.2 


\section{Comunicação e Cultura Organizacional: análise de um grupo de empresas sediadas no Brasil}

Dissertação apresentada ao Programa de PósGraduação em Ciências da Comunicação (PPGCOM) da Escola de Comunicações e Artes da Universidade de São Paulo, como requisito para obtenção do titulo de Mestre em Ciências da Comunicação.

Área de Concentração: Interfaces Sociais da Comunicação

Linha de Pesquisa: Políticas e Estratégias da Comunicação

Data de aprovação: 01/04/2016

Versão corrigida

Banca Examinadora:

Prof. ${ }^{a}$ Dra. Maria Aparecida Ferrari (Orientadora)

Prof. Dr. Germano Glufke Reis

Prof. Dr. Mitsuru Higuchi Yanaze 
Com todo meu amor e gratidão, para Arnaldo e Beatriz, que deram muito mais sentido e sentimento à minha vida. 


\section{AGRADECIMENTOS}

Agradeço à Prof. Dra. Maria Aparecida Ferrari por me acolher no Programa e me incentivar sempre ao longo desses anos de trabalho. Ao receber sua confiança e suporte necessários para finalizar a dissertação, tive mais do que sua orientação; fui constantemente instigada a buscar o meu melhor. Cresci e aprendi muito. Sua dedicação, tempo e paciência foram fundamentais. Muito obrigada, Professora!

Sem palavras para agradecer à Roberta Correia e à toda equipe da Comunicação Corporativa da Bunge Brasil que, por inúmeras vezes, me apoiaram, me escutaram, acompanharam minhas aflições e meus momentos de distanciamento para que essa dissertação fosse possível.

Obrigada à eterna professora Ivone de Lourdes Oliveira, que plantou uma semente quando eu ainda nem imaginava em colher frutos. E à professora de vida, Jussara Belo, que mesmo sem saber, tem sido meu exemplo desde os primeiros aprendizados na profissão.

Às empresas e profissionais entrevistados, agradeço por dedicarem seu tempo e o investirem na pesquisa acadêmica. Obrigada, Vinícius, estatístico de mão cheia que sempre esteve disponível e me ajudou com os números e resultados da pesquisa.

Aos meus amigos, de BH e de SP, muito obrigada por tornarem essa jornada mais leve e acompanharem de perto ou de longe com suas palavras de incentivo, estando sempre comigo quando foi preciso "esfriar a cabeça". À minha avó, pelas orações, e minhas tias, tios, primos e primas pela torcida mais do que especial!

Aos meus pais, Fernando e Patrícia, e à minha irmã, Fernanda, agradeço por compreenderem minhas escolhas, por nunca deixarem de acreditar em mim, por toda a dedicação para que eu pudesse estudar, por serem meu alicerce e me transmitirem a certeza de que terminaria tudo bem. Em mim sempre haverá um pouco de vocês. E vice-versa.

Agradeço ao Arnaldo, meu marido, meu amor, melhor amigo, melhor companheiro e melhor pai do mundo, por embarcar nessa comigo. Todas as palavras serão pouco para dizer o quanto você foi essencial para que esse trabalho se concretizasse. Mais do que tudo, tive seu apoio incondicional, do início ao fim, assumindo as tarefas com a Bia e me deixando tranqüila para prosseguir. Essa conquista é tão sua quanto minha! Vamos comemorar!

Beatriz, minha docinha, obrigada por seu sorriso encantador todas as vezes que eu finalizava um capítulo. Você chegou e transformou tudo em alegria e amor! Foi só por você, viu? 
A abertura à experiência do saber modifica $e$ constrói o próprio pesquisador.

(autor desconhecido) 


\title{
RESUMO
}

Esta dissertação tem por objetivo verificar se a cultura organizacional influencia a prática de comunicação nas empresas brasileiras. Para tanto, aplicou-se uma sondagem online com 50 organizações que atuam no país, buscando identificar também os traços culturais mais marcantes no âmbito corporativo brasileiro. $\mathrm{O}$ resultado da pesquisa mostrou que a maior parte das empresas analisadas tem perfil cultural do tipo Clã, ou seja, apresentam uma cultura de preservação, privilegiam relações harmoniosas que se confundem com as relações familiares, convivendo diariamente com paternalismo e acentuada lealdade entre líderes e liderados. Em contrapartida, as empresas pesquisadas afirmaram exercer atividades de comunicação com alto nível de excelência, priorizando ações simétricas e transparentes. Analisar a relação entre cultura e comunicação leva à compreensão dos motivos pelos quais o profissional brasileiro tem uma maneira própria de gerenciar e administrar as relações no ambiente corporativo, impactando também os relacionamentos entre pessoas, grupos e países. Para quem tem o desafio de atuar como comunicador em um ambiente cada vez mais competitivo e global é determinante conhecer bem a cultura organizacional, seus tipos e suas interferências na sociedade.

Palavras-chave: comunicação, cultura organizacional, gestão brasileira, relações públicas

\begin{abstract}
This research aims to verify whether the organizational culture influences the practice of communication in Brazilian companies. Therefore, we applied an online survey with 50 organizations operating in the country, also seeking to identify the most significant cultural traits in the Brazilian corporate environment. The survey results showed that most of the companies analyzed have cultural-type Clan profile, ie, have a conservation culture, favoring harmonious relations that are confused with family relationships, living daily with paternalism and sharp loyalty among leaders and employees. In contrast, the companies surveyed said exercise communication activities with a high level of excellence, prioritizing symmetrical and transparent actions. To analyze the relationship between culture and communication leads to understanding of the reasons why the Brazilian professional has its own way of managing and administering the relationships in the corporate environment, also affecting the relationships between people, groups and countries. For those who have the challenge of working as a communicator in an increasingly competitive and global environment is critical familiar with the organizational culture, their types and their influence in society.
\end{abstract}

Keywords: communication, organizational culture, Brazilian management, public relations 


\section{LISTA DE SIGLAS E ABREVIATURAS}

AmLat: América Latina

CEO: Chef Executive Officer

CEPAL: Comisión Económica para América Latina y el Caribe

GINEBRA: Gestão Empresarial para a Internacionalização de Empresas Brasileiras

OCAI: Organizational Culture Assessment Instrument

OCDE: Organização Mundial para Cooperação e Desenvolvimento Econômico

IBGE: Instituto Brasileiro de Geografia e Estatística

PIB: Produto Interno Bruto

Pnad: Pesquisa Nacional por Amostragem Domiciliar

RP: Relações Públicas

UNCTAD: Conferência das Nações Unidas sobre Comércio e Desenvolvimento 
Quadro 1: Perfil social, econômico e político do Brasil

Quadro 2: Abordagens e principais enfoques sobre cultura .29

Quadro 3: As dimensões de cultura nacional de Hofstede .33

Quadro 4: Níveis de cultura organizacional, segundo Schein .39

Quadro 5: Características das organizações em ambientes interculturais .42

Quadro 6: Os quatro principais tipos de cultura organizacional 46

Quadro 7: Os quatro modelos de práticas de relações públicas 61

Quadro 8: Categorias e princípios genéricos de relações públicas de excelência .64

Quadro 9: Relação entre cultura organizacional e as percepções de 99 comunicação nas empresas pesquisadas 
Figura 1: Modelo de Valores Competitivos 45

Figura 2: Visão integrada do Modelo de Ação Cultura Brasileiro 49

Figura 3: Proporção de cada empresa, segundo o grupo obtido pela análise de cluster ........76

Figura 4: Matriz de análise para cultura - Tipologia de Cultura Organizacional 79

Figura 5: Matriz de análise para comunicação - percepções sobre a prática 81 de comunicação

Figura 6: Matriz da tipologia de cultura organizacional com aplicação do resultado 86 por empresa pesquisada

Figura 7: Matriz de comunicação com aplicação do resultado por empresa pesquisada .93 
Tabela 1: Proporção de cada tipo cultural, segundo Cameron e Quinn (2006) Anexo C

Tabela 2: Tipos de cultura para os agrupamentos de empresas .75

Tabela 3: Resumo do agrupamento das 50 empresas pesquisadas Anexo C

Tabela 4: Número de perguntas respondidas, soma e proporção de cada empresa ..... Anexo C

Tabela 5: Resumo do agrupamento das empresas pesquisadas, Anexo C sobre o tema comunicação

Tabela 6: Medidas-resumo da proporção considerando o agrupamento, sobre o tema .....76 comunicação 


\section{SUMÁRIO}

INTRODUÇÃO

CAPÍTULO 1: Globalização e internacionalização de empresas

1.1 Globalização e sociedade contemporânea: elementos para contextualizar as organizações atuais

1.2 Internacionalização e mudanças: elementos que pressionam a sociedade e as organizações

1.3 Internacionalização de empresas: o novo fluxo

CAPÍTULO 2: Cultura como dimensão intrínseca dos processos sociais

2.1 Cultura e seus conceitos

2.2 Cultura nacional: as dimensões de Hofstede

2.3 Cultura Organizacional: o olhar de Schein

$2.4 \mathrm{O}$ desafio da gestão intercultural nas organizações 40

2.5 Tipos de cultura organizacional, segundo Cameron e Quinn 44

2.6 Traços culturais brasileiros: características definidas por Tanure

CAPÍTUlo 3: O papel da Comunicação e das Relações Públicas Internacionais

3.1 Cultura e Comunicação: duas faces da mesma moeda

3.2 Relações Publicas Internacionais para as organizações se adaptarem a ambientes culturais distintos

3.3 Os quatro modelos de Relações Públicas

3.4 A Teoria da Excelência em Relações Públicas

CAPÍTULO 4: Metodologia: descrição da pesquisa realizada

4.1 Características e critérios de seleção da amostra

4.2 Instrumentos de pesquisa 69

4.3 Procedimentos preparatórios para análise dos resultados obtidos 


\section{SUMÁRIO}

CAPÍTULO 5: Apresentação e análise dos dados

5.1 Matrizes para análise dos dados $\quad 78$

5.2 Perfil da Amostra $\quad 82$

5.3 Cultura Clã é o tipo cultural predominante nas organizações pesquisadas $\quad \mathbf{8 4}$

5.4 Organizações pesquisadas praticam comunicação estratégica e baseada nos $\quad 89$ princípios de excelência

5.5. Comunicação e Cultura: as duas principais variáveis da pesquisa

$\begin{array}{ll}5.6 \text { Análise das questões de pesquisa } & \mathbf{9 7}\end{array}$

CONSIDERAÇÕES FINAIS

$\begin{array}{ll}\text { Restrições da pesquisa e sugestões para estudos futuros } & 103\end{array}$

$\begin{array}{ll}\text { REFERÊNCIAS } & 105\end{array}$

$\begin{array}{ll}\text { ANEXOS } & 112\end{array}$

Anexo A: Questionário da pesquisa quantitativa

Anexo B: Análise do roteiro da pesquisa

Anexo C: Tabelas de análise estatística 


\section{INTRODUÇÃOO}

Está cada vez mais evidente que o fenômeno de globalização colaborou para impulsionar grandes mudanças e transformações mundiais ao longo do século XX e continua influindo na entrada do século XXI. A evolução das tecnologias da informação, a dissolução de fronteiras geográficas e informacionais, os movimentos políticos que têm transformado diversos países, a criação e também a dissolução dos blocos econômicos têm promovido uma mudança no comportamento e nos relacionamentos dos indivíduos no mundo, o que nos leva a concluir que existe a necessidade de maior interdependência entre as pessoas, grupos sociais, empresas e nações.

O espaço de atuação das empresas se expandiu e não está mais restrito apenas aos muros altos ou edifícios envidraçados. No século XXI esse território é o mundo como um todo: um espaço heterogêneo, multicultural, interdependente e fortemente conectado. $\mathrm{O}$ aumento da intensidade gradativa do fenômeno merece destaque. Segundo Fleury e Fleury (2012), globalização é um processo em função do qual as interconexões e interdependências nas várias áreas da atividade humana vão gradativamente aumentando. Um exemplo dessa aceleração, que tem relação direta com o tema do presente estudo, é o fato de a globalização transcender a operacionalização da sociedade e das organizações, perpassando também por relações entre os indivíduos, comportamentos e crenças.

Finuras (2007) afirma que esse processo trata da configuração de uma nova era de interação entre países, economias, povos e culturas. Portanto, diante desse cenário não é possível ignorar a importância e a influência da cultura e das relações interculturais. O fenômeno da globalização tem pressionado as organizações para dar mais atenção às diferenças e semelhanças culturais, assim como aos efeitos sobre o comportamento dos consumidores, funcionários, parceiros, fornecedores e demais públicos com os quais elas se relacionam no seu cotidiano. Tanto nas relações profissionais, quanto nas relações pessoais, tornou-se imprescindível identificar e reconhecer as diferenças culturais para atuarmos em sociedade e buscar caminhos para se adaptar aos desafios presentes no cotidiano.

Hoje é necessário compreender e dominar alguns códigos culturais; seja por meio da linguagem verbal ou não verbal, hábitos, crenças, valores, comportamentos, religião e principalmente, saber se relacionar em sociedade para minimizar as diferenças e se aproximar de outras culturas. Segundo Castells (2000), o que caracteriza o desenvolvimento da 
economia informacional global é exatamente seu surgimento em contextos culturais/nacionais muito diferentes, exercendo influência em todos os países e levando a uma estrutura de referências multiculturais. Ele é categórico ao afirmar que culturas manifestam-se fundamentalmente por meio de sua inserção nas instituições e organizações.

Assim, considerando o papel relevante da comunicação na gestão intercultural, nossa premissa é que a cultura nacional influencia diretamente o comportamento das organizações, independentemente de onde estão localizadas, e a comunicação que as empresas praticam tem relação direta com a cultura organizacional. De acordo com Allen e Dozier (2012), quanto mais marcadas são as diferenças culturais entre a organização e seus públicos de relacionamento, maiores são os desafios de comunicação e maiores são as chances de mal entendidos e consequências que estão fora do controle.

Freitas (1991, 2008) argumenta que as culturas são criadas, sustentadas, transmitidas e mudadas através da interação social, que na empresa se expressa por meio de papéis informais na rede de comunicação. Essa rede formada pelos papéis informais faz a amarração das diversas partes da organização, transmitindo informações e interpretando os significados das informações para os outros envolvidos.

Essa dissertação pretende colaborar com o debate sobre sinergias entre comunicação e interculturalidade, competências notadamente importantes para empresas que se propõem a atuar de forma global (Finuras, 2007, Álvarez, 2009). Assim, o objeto de pesquisa deste trabalho são empresas brasileiras e a relação entre a cultura organizacional e a comunicação praticada por elas.

No Brasil, embora o discurso empresarial tenha evoluído muito e a prática evidentemente não seja a mesma dos anos 1950, percebemos que algumas características e traços culturais são muito fortes e continuam a marcar as relações no ambiente corporativo e, por consequência, o processo de comunicação das organizações. As pesquisas realizadas por Tanure (2005) comprovam que o brasileiro tem uma maneira própria de gerenciar e administrar as relações corporativas. E, cada vez mais, fica claro que conhecer bem as diferenças e os tipos de culturas organizacionais é determinante para quem tem o desafio de atuar como comunicador nas empresas em um mundo cada vez mais competitivo. 
Nesse contexto é relevante destacar que ainda são poucos os estudos brasileiros que abordam a relação entre a cultura nas organizações e o processo de comunicação. Existem estudos locais sobre cultura nacional e cultura organizacional, separadamente, mas são raras as pesquisas que fazem a conexão entre a cultura organizacional e a comunicação. A fim de exemplificação, vale citar que, durante a fase de revisão de literatura para realização deste trabalho, identificou-se uma carência de literatura de pesquisas que abordem a relação entre comunicação e cultura, principalmente voltadas para a realidade do Brasil e demais países da América Latina.

As referências dos estudos, na maioria das vezes, são realizadas a partir de autores estrangeiros, com vivências e realidades socioculturais completamente distintas das brasileiras. Os estudos sobre a relação entre cultura e comunicação abrem diferentes possibilidades de abordagens, principalmente quando são consideradas as realidades locais e não apenas a visão e os referenciais de autores estrangeiros. Mais do que isso, é preciso buscar novas formas de se compreender a diversidade presente nas realidades organizacionais brasileiras, ou mesmo considerando aspectos culturais nos enfoques já existentes.

Assim, detectou-se a necessidade de se realizar uma pesquisa de campo, com um olhar mais apurado sobre como a cultura organizacional brasileira age diretamente sobre o processo de comunicação e vice-versa. Nesse sentido, o estudo teve como objetivos: 1) identificar os traços da cultura organizacional presentes em empresas brasileiras; 2) verificar se os traços da cultura organizacional interferem na pratica da comunicação nas empresas brasileiras; 3) avaliar em que extensão os elementos da cultura organizacional colaboram ou impedem para a realização de um processo de comunicação estratégico no Brasil.

\section{Metodologia}

Com o intuito que esses objetivos fossem contemplados, realizou-se uma sondagem com 50 profissionais responsáveis pela área de comunicação em empresas brasileiras. O questionário da pesquisa foi dividido em duas partes, com 17 questões sobre cultura e comunicação. Os dados coletados foram analisados com o apoio da Teoria da Excelência coordenada por Grunig et. al. (1992), das dimensões de cultura nacional de Hosfstede (1994), da tipologia de cultura organizacional de Cameron e Quinn (2006) e do modelo de ação cultural brasileiro de Barros e Prates (1996). 
Esses e outros autores citados ao longo do trabalho contribuíram para que pudéssemos responder às seguintes questões de pesquisa: 1) Quais são as características culturais brasileiras que influenciam a cultura organizacional? 2) De que forma as questões culturais interferem na pratica de comunicação das empresas? 3) Em que extensão os elementos da cultura organizacional colaboram ou impedem para realização de um processo estratégico de comunicação?

A dissertação está dividida em cinco capítulos. Os três primeiros capítulos abordam a fundamentação teórica utilizada para embasar o estudo. O primeiro deles descreve a globalização enquanto fenômeno que proporcionou novas configurações para o mundo e para o ambiente empresarial e contribuiu para compor o cenário que serve de pano de fundo no debate sobre comunicação e cultura nas organizações. O objetivo é contextualizar o objeto de estudo dessa dissertação, o ambiente e o contexto em que estão inseridas as organizações brasileiras no século XXI e que, com aumento dos fluxos de internacionalização e a influência desse processo sobre as empresas e a sociedade, sofreram transformações, tanto nos seus relacionamentos, quanto nos modelos de gestão.

O segundo capítulo trata da cultura e suas dimensões. Após uma breve descrição conceitual sobre o tema, são apresentados os enfoques de Geert Hofstede (1980) sobre cultura nacional e de Edgar Shein $(1992,2009)$ sobre cultura organizacional. Além disso, o Modelo de Ação Cultural Brasileiro de Barros e Prates (1996) e Tanure (2005) e o modelo de valores competitivos e tipologia de cultura organizacional de Cameron e Quinn (2006) como abordagens relevantes para a discussão sobre a influência da cultura no ambiente empresarial.

O terceiro capítulo apresenta dois estudos globais, que foram aplicados em diferentes países do mundo e que têm sido essenciais para entender a prática das Relações Públicas no contexto organizacional e da sociedade: a tipologia dos modelos de prática de Relações Públicas, desenvolvido por Grunig e Hunt (1984) e a Teoria da Excelência, preconizada por James Grunig (1992).

O quarto capítulo apresenta a metodologia da pesquisa utilizada e antecipa algumas informações relevantes sobre tipo e características da amostra, detalhando como foi realizada a investigação das características e traços culturais de organizações brasileiras e a sua relação com a prática de comunicação e Relações Públicas nas empresas. Além disso, traz a análise dos resultados obtidos a partir da pesquisa, sob a luz de um estudo estatístico embasado nos temas centrais que foram abordados no questionário de pesquisa: cultura e comunicação. 
Esses resultados foram interpretados e aplicados em matrizes de análise, de forma a interagir com as questões de pesquisa, os objetivos propostos e o referencial teórico elaborado como base da dissertação.

Por fim, apresentamos as conclusões da dissertação, verificamos de que forma o estudo atendeu aos objetivos iniciais e apontamos as dificuldades e limitações encontradas, bem como sugestões para futuros estudos sobre o tema. 


\section{CAPÍTULO 1: Globalização e internacionalização de empresas}

\subsection{Globalização e sociedade contemporânea: elementos para contextualizar as organizações}

Este capítulo constitui a primeira parte do referencial teórico do estudo apresentado. Aborda a globalização como fenômeno que proporcionou novas configurações para o mundo e para o ambiente empresarial e contribuiu para compor o cenário que serve de pano de fundo no debate sobre comunicação e cultura nas organizações.

O objetivo é contextualizar o ambiente em que estão inseridas as organizações brasileiras no século XXI que, com aumento dos fluxos de internacionalização e a influência desse processo sobre a sociedade, sofreram transformações, tanto nos seus relacionamentos, quanto nos modelos de gestão.

A globalização é vista como um fenômeno político e econômico importante na atualidade e tem sido analisada por diversas perspectivas: antropológica, econômica social, cultural e política, gerando opiniões divergentes em função das consequências que tem afetado a vida das pessoas, organizações e sociedade. Não é a intenção aqui assumir posições ideológicas sobre as consequências oriundas do fenômeno da globalização, sejam positivas ou negativas, mas apresentar conceitos que possibilitem delinear o cenário atual, para fins de contextualização do presente estudo.

Dicken (1992) definiu globalização como a mudança nos padrões tradicionais de produção internacional, investimento e comércio. Para Ohmae $(1995,2002)$ o que importa destacar no ambiente globalizado é a ausência de fronteiras e barreiras ao comércio entre nações, o que significaria na emergência de um mercado global único para o trabalho e o capital. Nessa linha, Berger (2005) considera que a globalização é a aceleração dos processos da economia internacional no sentindo da unificação dos mercados mundiais.

Em uma perspectiva histórica, vale recorrer a Baumann (1996) e Chesnais (1995) que previram que a globalização seria dividida em quatro fases distintas: a globalização financeira, ocorrida na década de 1970, que foi marcada por um rápido avanço tecnológico e início da circulação de moeda entre países; a globalização comercial, na década de 80, que reduziu barreiras ao comércio internacional, movimentando produtos acabados e matériasprimas pelo mundo; a globalização produtiva, na década de 1990, que marcou a organização 
dos sistemas de produção e operação globalizadas; e por fim, a globalização institucional, marcada pela crise de 2008, que impactou fortemente todas as dimensões anteriores financeira, econômica, produtiva, demográfica - e vem gerando consequências diretas no plano institucional.

Segundo a perspectiva mais crítica e atual do fenômeno, Kaplinsky (2005) define que a globalização é um processo complexo e multidimensional, com redução de barreiras não somente no âmbito financeiro, econômico e material, mas também para os fluxos de conhecimento, informação, ideias e crenças. A aceleração do ritmo desse fenômeno é determinante para diferenciá-lo de fenômenos anteriores, como a modernidade e a pósmodernidade, por exemplo, levando a uma mudança na sociedade com impactos sobre a noção de tempo e espaço (Castells, 2000) e tornando o mundo um ambiente descontínuo, contraditório e multifacetado.

Para alguns desses autores mencionados anteriormente, o fenômeno não é novo, mas o termo 'globalização' sim. Não é possível precisar o período exato de sua origem, mas sabe-se que ele se intensificou a partir de 1960, principalmente com a redução do custo do transporte e o advento da tecnologia da informação. Para Ganesh, Zoller e Cheney (2005), embora fenômenos globais, tais como as migrações em massa, propagação de doenças, conquistas de países pelo colonialismo e comércio internacional de mercadorias não sejam novidades, a natureza e a forma que globalização assumiu levaram a sociedade a uma nova configuração econômica, política e social desde o final dos anos 80 .

Interessante notar que a globalização transcende a operacionalização da sociedade e das organizações, perpassando também por relações entre os indivíduos, comportamentos e crenças. Nesse sentido, Lescent-Giles (2003) diz que a globalização vai além da mera internacionalização do mercado. Segundo ele, quando o fenômeno da globalização atinge seu ápice, ele produz organizações com corpos gerenciais, conselho de administração e acionistas transnacionais.

Como última reflexão, Ianni (apud Ferrari, 2011, p. 139) traz um olhar que complementa os demais conceitos apresentados ao definir globalização como um fenômeno que transcende as esferas mais tangíveis das interações entre os povos e países e altera as relações sociais e culturais, instaurando novas maneiras de comportamento na sociedade, gerando o que o autor 
propõe como um processo civilizatório. Essa é a definição que mais se aproxima do tema deste trabalho, portanto, é a que será considerada como referência ao longo da pesquisa.

\subsection{Internacionalização e mudanças: elementos que pressionam a sociedade e as organizações}

Frente a esse cenário, existe uma interdependência cada vez maior entre indivíduos, grupos sociais, empresas, economias e nações que é gerenciada pela tecnologia por meio da rapidez e do acesso ilimitado e franqueado da informação. Os ambientes de mercado, da política, da economia e das organizações passaram a se apresentar mais desconexos, múltiplos, enquanto a instabilidade, a vulnerabilidade, a subjetividade e a sensibilidade ocupam um espaço maior na relação entre as pessoas.

O indivíduo, agora mais ativo e atuante, passa a ter uma infinita possibilidade de interpretação do novo mundo que o cerca. Isso se reflete nas interações sociais e econômicas, trazendo novas palavras-chaves ao centro das discussões, tais como pluralismo, relativismo e heterogeneidade.

Para garantirem sua sobrevivência nesse ambiente, as organizações passaram a dar mais atenção aos efeitos das diferenças e das semelhanças culturais sobre o comportamento dos consumidores, funcionários, parceiros, fornecedores e os públicos com os quais elas relacionam cotidianamente. Tanto nas relações profissionais, quanto nas relações pessoais, tornou-se imprescindível identificar e reconhecer as diferenças culturais.

Seja por pressões de mercado ou por atitude empreendedora da alta direção, para se manterem em um mercado global as empresas foram desafiadas a desenvolver novos modelos de gestão que vão desde a ampliação da análise de riscos, a disposição à implementar processos de inovação, a adoção de atitudes que reforçam a proatividade e, principalmente, à adaptação da empresa a diferentes ambientes e culturas.

Barreto e Rocha (2003) acreditam que esse processo, conhecido como um processo de internacionalização das empresas, ocorre como uma consequência gradual e inevitável de ajustes, pressões ou transformações relativos tanto ao ambiente externo como ao interno das organizações. 
Para o presente trabalho interessa compreender que o fenômeno da globalização da sociedade e das organizações, assim como o processo de internacionalização de economias e empresas é um tema central que serve para auxiliar a compreensão de conceitos que permeiam a pesquisa da dissertação questão.

Fleury e Fleury (2012), lideraram a criação de um grupo de pesquisadores brasileiros que integram o projeto GINEBRA (Gestão Empresarial para a Internacionalização de Empresas Brasileiras) ${ }^{1}$, com objetivo principal de entender a dinâmica da internacionalização de empresas locais visando apoiar a intensificação da participação no mercado internacional. A contribuição do grupo Ginebra é relevante na medida em que auxilia na caracterização das organizações que buscam a internacionalização, definido aspectos comportamentais e traços diferenciadores.

Fleury e Fleury (2012) conceituam a internacionalização como um fenômeno associado a atores sociais, as empresas, os mercados e os países, que de alguma maneira estão envolvidos no processo de globalização e devem ser compreendidos em diferentes momentos históricos, que caracterizam dinâmicas e relações específicas entre esses atores. Este é o conceito de internacionalização que será a tomado como referência base para essa dissertação. Na sequência abordaremos como as empresas brasileiras têm vivenciado esse momento.

\subsection{0 momento econômico do país para as empresas brasileiras}

De modo geral, o que se percebe é que empresas que decidiram se internacionalizar na América Latina, entre os anos de 1970 e 1980 pagaram caro pela falta de competitividade e por fraquezas relacionadas à ausência de uma mentalidade global. Os resultados desse movimento na região foram modestos, o que levou as empresas a passarem por um posterior momento de reestruturação para conseguir se desenvolver de forma planejada nos mercados internacionais.

\footnotetext{
${ }^{1}$ O projeto GINEBRA foi desenvolvido sob a coordenação do professor Afonso Fleury, do Departamento de Engenharia de Produção da Escola Politécnica da Universidade de São Paulo (USP), entre fevereiro de 2006 a janeiro de 2010. O projeto, que contou com o apoio da FAPESP, resultou em sete livros, 15 dissertações de mestrado e 23 teses de doutorado e aprofundou a cooperação entre grupos de pesquisa brasileiros na área e gerou subsídios para companhias nacionais interessadas em atuar no exterior. O principal objetivo foi a geração de conhecimentos sobre o processo de internacionalização da atividade industrial visando (a) desenvolver ferramental teórico-conceitual voltado às condições locais, (b) apoiar as empresas brasileiras na intensificação da participação no mercado internacional e (c) subsidiar as instâncias formuladoras de políticas públicas.
} 
Apenas a partir da década de 90 o ambiente empresarial latino americano e também o brasileiro começou a evoluir e buscar o mercado internacional, sempre lidando com condições desfavoráveis. A globalização dos mercados, a concorrência acirrada, a abertura econômica, a conquista da estabilidade política, as políticas de sustentabilidade e a maior interferência dos grupos sociais nas organizações são alguns dos fatores que colocaram as empresas da região em um cenário de transição (Ferrari, 2000).

Além dos desafios relacionados ao contexto corporativo, as empresas contam com outros desafios que têm origem em seu próprio contexto nacional (Khanna e Palepu, 1999). É o caso do Brasil dos anos dois mil. Após experimentar um período de bons índices econômicos, o país entrou em uma estagnação com fortes consequências para empresas, indústrias e para a sociedade produtiva. Ao longo dos últimos 15 anos, o país enfrentou altos e baixos na economia, conseguiu se isolar da crise internacional de 2008, mas não soube aproveitar a recuperação dos países desenvolvidos no cenário externo para se manter em um patamar próximo do desenvolvimento.

No final de 2010, por exemplo, as projeções de crescimento para a região da América Latina, incluindo o Brasil, eram melhores do que para as economias desenvolvidas, segundo relatório anual do Fundo Monetário Internacional - FMI (2010). Estados Unidos e Europa começavam a dar sinais de recuperação da crise que os atingiu entre 2008 e 2009. O relatório do FMI registrava que a América Latina e o Brasil apresentavam instituições financeiras, monetárias e fiscais mais sólidas do que a duas décadas atrás. Além disso, com disponibilidade abundante dos recursos naturais que estavam em alta demanda no mundo todo, e com políticas sociais aparentemente coerentes, o Brasil despontava e era considerado país de destaque internacionalmente.

Entretanto, outro estudo do Banco Interamericano de Desenvolvimento (BID, 2012) publicado dois anos mais tarde já aponta para um cenário oposto. Um exemplo a ser considerado é a queda drástica das exportações da região, alcançando apenas 1,5\% em 2012, enquanto entre 2010 e 2011 chegou a registrar dois dígitos de crescimento. O país começava a dar seus primeiros sinais. Em 2014, ano de eleições presidenciais no Brasil, o mercado já percebia que as condições econômicas não eram tão favoráveis.] 
A mudança foi rápida. Enquanto a Europa se recuperava da crise, países da América Latina e o Caribe registravam desaceleração econômica. Segundo relatório do Fundo Monetário Internacional (FMI), o Produto Interno Bruto (PIB) do bloco teve crescimento abaixo de 1\%, enquanto a economia mundial se expandiu cera de $4 \%$. Para melhor entendimento do cenário em que as empresas brasileiras estão inseridas, o Quadro 1 apresenta dados e informações que ajudam a contextualizar a realidade corporativa no país.

\section{Quadro 1: Perfil social, econômico e político do Brasil}

\begin{tabular}{|l|l|l|} 
Aspectos Sociais & Aspectos Econômicos & Aspectos Político-Culturais \\
\hline $\begin{array}{l}\text { População: } \\
204 \text { milhões }\end{array}$ & $\begin{array}{l}\text { Crescimento do PIB: - 3,8\% } \\
(2015) \text { e - 0,9 (2014) }\end{array}$ & $\begin{array}{l}\text { Língua oficial: português } \\
\text { Colonização: portuguesa }\end{array}$ \\
\hline IDH: 0,744 (79) & $\begin{array}{l}\text { Inflação anual: } \\
10,6 \%(2015) \text { X 6,5\% (2014) }\end{array}$ & $\begin{array}{l}\text { Histórico de ditadura militar } \\
\text { e violência urbana }\end{array}$ \\
\hline $\begin{array}{l}\text { Densidade: } \\
23 \text { hab./m2 }\end{array}$ & $\begin{array}{l}\text { Número de } \\
\text { empresas:12.904.523 }\end{array}$ & $\begin{array}{l}\text { Sistema de governo: } \\
\text { democracia presidencialista }\end{array}$ \\
\hline $\begin{array}{l}5.561 \text { cidades no país, } \\
\text { sendo as principais: } \\
\text { SP, RJ e Brasília. }\end{array}$ & $\begin{array}{l}\text { Índice de desemprego: } \\
6,8 \%(2015) \text { X 4,9\% (2014) }\end{array}$ & $\begin{array}{l}\text { Iniciativa privada sobrepõe } \\
\text { interesses do governo. }\end{array}$ \\
\hline
\end{tabular}

Fontes: Folha.com, IBGE, CEPAL/CELADE, datosmacro.com, tradingeconomics.com, Instituto Brasileiro de Planejamento e Tributação (IBPT), 2014 e 2015.

Segundo o Quadro 1, os números da coluna "aspectos econômicos" não deixam dúvidas sobre a gravidade da situação econômica brasileira. Nos últimos seis anos, o Brasil passou de promissor e destaque internacional para um país em crise, e a maioria dos países da região latinoamericana também sofreu uma deterioração nesses indicadores em anos recentes.

Os motivos que levaram a atual situação econômica do Brasil são muitos, mas alguns deles merecem destaque especial: a falta de investimentos programados em infraestrutura, o que tem levado o país a perder competitividade tanto no ambiente interno quanto externo; e a crescente perda de credibilidade nas instituições e nos representantes públicos, com 
escândalos de impunidade e corrupção, o que amplia ainda mais as perspectivas negativas em relação ao futuro. Por fim, a combinação dos dois motivos citados anteriormente gera um terceiro, que mantém ainda mais forte a crise: a desconfiança do mercado internacional.

Com crescimento abaixo do ritmo potencial, o país precisa ajustar suas contas públicas, em um momento em que muitas economias da região enfretam desequilíbrios fiscais. Nesta situação, o governo tem a tendência a pedir ajuda para o setor produtivo. Entretanto, a preocupação com a atual situação econômica do Brasil vem fazendo com que empresários adiem investimentos e novos empreendedores aguardem momentos menos incertos para iniciar seus projetos.

Além disso, como sabemos, países da América Latina, incluindo o Brasil, precisam lidar diariamente com inúmeros obstáculos ao desenvolvimento em áreas que incluem igualdade social, violência, saúde pública, educação, produtividade, integração, segurança alimentar e adaptação às mudanças culturais. No Brasil, particularmente, características e traços culturais são muito fortes e marcantes no ambiente corporativo. O brasileiro tem seu jeito próprio de gerenciar e administrar as relações. Assim, na sequência, partiremos para uma análise mais profunda da cultura e seus conceitos, com o objetivo de buscar subsídios para avaliar o cenário brasileiro por diferentes ângulos. 


\section{CAPÍTULO 2: Cultura como dimensão intrínseca dos processos sociais}

\subsection{Cultura e seus conceitos}

Este capítulo aborda a cultura e suas dimensões. Após uma breve descrição conceitual sobre o tema, são apresentados os enfoques de Geert Hofstede $(1997,2001)$ sobre cultura nacional e de Edgar Shein (1992) sobre cultura organizacional, como abordagens relevantes para a discussão sobre a influência da cultura no ambiente empresarial.

O conceito de cultura tem origem nas ciências sociais e é básico para a compreensão dos comportamentos, das normas, das crenças, dos mitos, dos ritos e das formas de comunicação existentes no mundo. Por isso, a cultura pode ser abordada de múltiplas maneiras e não há consenso entre os inúmeros estudiosos do tema sobre sua definição (Ferrari, 2011). Segundo Sriramesh (2012) observou, existem aproximadamente 164 definições de cultura e mais de 300 variações registradas na extensa literatura sobre o tema.

No início do século XXI, as preocupações e discursos sobre cultura referem-se a questões de identidade, gênero, diversidade, transformações sociais, consequiências dos impactos da tecnologia, conhecimento e inovação que, entre outras, mostram que essa temática é relevante para a análise dos comportamentos das pessoas em sociedade.

Como se nota, são temas abrangentes e suscitam diferentes análises e concepções. Alguns temas envolvem a Antropologia, disciplinas da Administração ou da Comunicação. É o esperado quando "vários fenômenos culturais, sociais e psicológicos interagem e criam uma dinâmica de complexo entendimento, com certeza, há poucas possibilidades de tratamento puramente objetivo, o que é peculiar das ciências sociais" (Barros e Prates, 1996. P. 14).

A definição de Tylor (apud Sackamnn, 1991, p. 8), considerado o fundador da Antropologia britânica enfatiza o aspecto intelectual da cultura: "Cultura ou civilização, tomadas no seu amplo sentido etnográfico, é todo aquele complexo que inclui conhecimento, crença, arte, moral, lei, costume e qualquer outra capacidade e hábitos adquiridos pelo homem enquanto membro da sociedade"

Já Barros e Prates (1996) destacam que a cultura não é uma herança genética predeterminada, mas sim o resultado da invenção social, uma estrutura de significados socialmente 
estabelecida. Por isso, segundo esses autores, a cultura é transmitida e apreendida através da interação, do processo de comunicação e do aprendizado, podendo sofrer mudanças ao longo dos tempos, como reforçam quando afirmam que

\begin{abstract}
O que temos é um processo recorrente vivo, entre a sociedade e a cultura, em que seus membros agem e manifestam a cultura que, em dado tempo, lhes imprime um padrão de comportamento particular, mas que se transforma em função do funcionamento dessa mesma sociedade ou de outras, numa perspectiva temporal mais longa. Convivem o tradicional e o novo, estabelecendo ambos uma troca dinâmica de elementos até um novo estado de equilíbrio (BARROS E PRATES, 1996, p.16)
\end{abstract}

Sob a perspectiva que acaba de ser citada, a cultura é algo externo ao indivíduo, com movimentos próprios. Em contraponto a essa visão, Hofstede (1997) entende que a cultura é uma programação mental, normalmente inconsciente e própria do indivíduo, deixando-o em liberdade para pensar, sentir e agir, dentro do condicionamento, que o ambiente social em que ele (indivíduo) está inserido, lhe permite. Para o autor, a programação mental difere de um grupo ou categoria de pessoas para outro e tem início já na família, quando o indivíduo ainda é criança. Essa programação continua na escola, no trabalho e nos outros ambientes por onde ele passar, como um prolongamento de todas as relações experimentadas pelo indivíduo ao longo da vida.

Um conceito mais pluralista e dinâmico entende que, em seu sentido mais amplo, a cultura pode ser compreendida também como um conjunto de valores que determina o comportamento humano e que permite que esse comportamento seja percebido pelos outros de forma compreensível. A materialização da cultura ocorre, portanto, por meio de expressões artísticas, manifestações sociais e lingüísticas. Trata-se de grupos de idéias e significados que são constantemente retrabalhados no contexto das interações diárias entre indivíduos (Martin, 2002). Essa seria uma perspectiva de compreender a cultura como uma forma de entender um determinado contexto e de nele atuar.

Seguindo também essa mesma linha, Geertz (2001) contribui com uma abordagem ainda mais contemporânea sobre cultura. Para ele, a função da cultura é dar significado ao mundo de forma a tornar possível seu entendimento. Assim, descreve que cultura é o sistema de concepções expressas herdadas em formas simbólicas, que permite ao homem se comunicar, perpetuar e desenvolver seu conhecimento sobre atitudes para a vida. 
Para demonstrar a complexidade que envolve o estudo da cultura, o Quadro 2 apresenta as diferentes abordagens e enfoques, passando por representantes da Antropologia, Psicologia, Comunicação e Linguagem.

\section{Quadro 2: Abordagens e principais enfoques sobre cultura}

\begin{tabular}{|c|c|c|c|c|}
\hline Abordagem & Focos de estudo & Representantes & Interesses de estudo & Hipóteses \\
\hline $\begin{array}{l}\text { Evolução } \\
\text { cultural }\end{array}$ & $\begin{array}{l}\text { Cultura }=\text { todo } \\
\text { complexo, que inclui } \\
\text { aspectos cognitivos, } \\
\text { comportamentais e } \\
\text { materiais adquiridos } \\
\text { pelo ser humano. }\end{array}$ & $\begin{array}{l}\text { C. Taylor } \\
(1871 ; 1903)\end{array}$ & $\begin{array}{l}\text { Busca de leis da } \\
\text { evolução e origens }\end{array}$ & $\begin{array}{l}\text { Povos educados são } \\
\text { superiores a povos } \\
\text { "primitivos" }\end{array}$ \\
\hline \multirow{4}{*}{$\begin{array}{l}\text { Particularismo } \\
\text { histórico }\end{array}$} & \multirow[t]{2}{*}{$\begin{array}{l}\text { Fatos, traços e } \\
\text { elementos da } \\
\text { antropologia física. }\end{array}$} & \multirow[t]{2}{*}{ F. Boas } & \multirow{2}{*}{$\begin{array}{l}\text { Coleta de dados em } \\
\text { campo e descoberta de } \\
\text { seus princípios sui } \\
\text { generis. }\end{array}$} & $\begin{array}{l}\text { A antropologia } \\
\text { deveria ser histórica, } \\
\text { indutiva e científica }\end{array}$ \\
\hline & & & & $\begin{array}{l}\text { O indivíduo é uma } \\
\text { unidade importante } \\
\text { de estudo }\end{array}$ \\
\hline & \multirow[t]{2}{*}{$\begin{array}{l}\text { "Supra-orgânica" } \\
\text { (o não-indivíduo) }\end{array}$} & \multirow[t]{2}{*}{ A. L. Kroeber } & \multirow{2}{*}{$\begin{array}{l}\text { Descoberta de padrões e } \\
\text { configurações de cultura } \\
\text { (busca de uma teoria } \\
\text { maior) }\end{array}$} & $\begin{array}{l}\text { Antropologia = } \\
\text { história (mais do que } \\
\text { ciência) }\end{array}$ \\
\hline & & & & $\begin{array}{l}\text { Indivíduos são } \\
\text { subordinados à } \\
\text { cultura }\end{array}$ \\
\hline \multirow{4}{*}{ Funcionalismo } & \multirow[t]{2}{*}{$\begin{array}{l}\text { Descoberta da estrutura } \\
\text { de um sistema natural e } \\
\text { tentativa de entender } \\
\text { como cada parte } \\
\text { funciona em relação ao } \\
\text { sistema }\end{array}$} & \multirow[t]{2}{*}{$\begin{array}{l}\text { A. R. Radcliffe- } \\
\text { Brow } \\
(1952 ; 1957)\end{array}$} & $\begin{array}{l}\text { Estrutura social = } \\
\text { abstração de } \\
\text { comportamento (nenhum } \\
\text { interesse em aspectos } \\
\text { psicológicos ou } \\
\text { biológicos) }\end{array}$ & $\begin{array}{l}\text { Conceito de cultura é } \\
\text { menos significativa } \\
\text { do que conceito de } \\
\text { sistemas sociais }\end{array}$ \\
\hline & & & $\begin{array}{l}\text { Estudo de estrutura } \\
\text { social: determina a } \\
\text { função de } \\
\text { comportamento sobre } \\
\text { como ele serve para o } \\
\text { bem estar de um grupo }\end{array}$ & $\begin{array}{l}\text { Antropologia = } \\
\text { ciência. Pessoas são } \\
\text { organizadas em } \\
\text { sistemas que } \\
\text { constituem um todo } \\
\text { cujas partes } \\
\text { contribuem para sua } \\
\text { totalidade }\end{array}$ \\
\hline & \multirow{2}{*}{$\begin{array}{l}\text { Cultura = conjunto de } \\
\text { regras para o } \\
\text { posicionamento de } \\
\text { pessoas em um sistema }\end{array}$} & \multirow[t]{2}{*}{$\begin{array}{l}\text { B. Mailinowski } \\
(1934 ; 1944)\end{array}$} & $\begin{array}{l}\text { Como os vários } \\
\text { elementos de cultura } \\
\text { contribuem para o todo? }\end{array}$ & \\
\hline & & & $\begin{array}{l}\text { Interessada nas } \\
\text { necessidades } \\
\text { psicológicas, biológicas e } \\
\text { sociais }\end{array}$ & $\begin{array}{l}\text { Cultura = um } \\
\text { instrumento pelo } \\
\text { qual as necessidades } \\
\text { humanas são } \\
\text { atendidas (sete } \\
\text { necessidades básicas) }\end{array}$ \\
\hline
\end{tabular}




\begin{tabular}{|c|c|c|c|c|}
\hline \multirow{3}{*}{$\begin{array}{l}\text { Materialismo } \\
\text { Cultural }\end{array}$} & $\begin{array}{l}\text { Cultura }= \\
\text { comportamento } \\
\text { observável }\end{array}$ & J. Stuart (1955) & $\begin{array}{l}\text { Influências ambientais e } \\
\text { tecno-ambientais }\end{array}$ & $\begin{array}{l}\text { Antropologia }= \\
\text { ciência }\end{array}$ \\
\hline & $\begin{array}{l}\text { "Culturologia" (cultura } \\
\text { existe independente } \\
\text { dos seres humanos) } \\
\text { Cultura = continuum } \\
\text { de elementos } \\
\text { interagentes embora os } \\
\text { indivíduos sejam } \\
\text { transportadores de } \\
\text { tradição cultural }\end{array}$ & L. White (1959) & Ciência de cultura & $\begin{array}{l}\text { Ecologia é influência } \\
\text { determinante na } \\
\text { cultura e sua } \\
\text { evolução }\end{array}$ \\
\hline & $\begin{array}{l}\text { Cultura }= \\
\text { comportamento }\end{array}$ & $\begin{array}{l}\text { M. Harris } \\
(1964)\end{array}$ & $\begin{array}{l}\text { Comportamentos } \\
\text { coletivos }\end{array}$ & $\begin{array}{l}\text { Cultura }= \\
\text { comportamento que é } \\
\text { determinado por } \\
\text { fatores tecno- } \\
\text { ambientais }\end{array}$ \\
\hline \multirow{4}{*}{$\begin{array}{l}\text { Idealismo } \\
\text { cultural: } \\
\text { antropologia } \\
\text { psicológica }\end{array}$} & \multirow[t]{2}{*}{$\begin{array}{l}\text { Cultura }=\text { o todo } \\
\text { integrado com } \\
\text { consistência }\end{array}$} & $\begin{array}{l}\text { R. Benedict } \\
(1934 ; 1942)\end{array}$ & $\begin{array}{l}\text { Cultura é determinante } \\
\text { de personalidade }\end{array}$ & $\begin{array}{l}\text { Cultura = padrão } \\
\text { consistente de } \\
\text { pensamento e ação = } \\
\text { todo integrado }\end{array}$ \\
\hline & & M. Mead (1939) & \multirow[t]{2}{*}{ Diferentes estilos de vida } & \multirow{2}{*}{$\begin{array}{l}\text { Cultura = é } \\
\text { personalidade de } \\
\text { seus membros e } \\
\text { determina e } \\
\text { determina } \\
\text { personalidade de } \\
\text { seus membros }\end{array}$} \\
\hline & "Superorgânica" & $\begin{array}{l}\text { A. L. Kroeber } \\
(1917)\end{array}$ & & \\
\hline & $\begin{array}{l}\text { Cultura = algo } \\
\text { internalizado por seres } \\
\text { humanos como um } \\
\text { mundo de significados }\end{array}$ & E. Sapir (1917) & & $\begin{array}{l}\text { A linguagem que } \\
\text { uma pessoa } \\
\text { internaliza afeta a } \\
\text { maneira pela qual ela } \\
\text { percebe o mundo }\end{array}$ \\
\hline \multirow{2}{*}{ Etnografia } & \multirow[t]{2}{*}{$\begin{array}{l}\text { Descrições culturais } \\
\text { baseadas na linguagem }\end{array}$} & $\begin{array}{l}\text { J. P. Spradley } \\
(1972)\end{array}$ & \multirow{2}{*}{$\begin{array}{l}\text { Uso de etnociência para } \\
\text { estudar a visão dos que } \\
\text { estão no lado dentro }\end{array}$} & \\
\hline & & $\begin{array}{l}\text { H. Garfinkel } \\
(1967)\end{array}$ & & \\
\hline Estruturalismo & Inconsciente coletivo & $\begin{array}{l}\text { C. Levi-Strauss } \\
(1920 ; 1949)\end{array}$ & $\begin{array}{l}\text { Aspectos psicológicos de } \\
\text { estruturas fundamentais } \\
\text { da mente }\end{array}$ & $\begin{array}{l}\text { História está viva nas } \\
\text { lembranças das } \\
\text { pessoas }\end{array}$ \\
\hline \multirow[b]{2}{*}{$\begin{array}{l}\text { Antropologia } \\
\text { simbólica }\end{array}$} & \multirow{2}{*}{$\begin{array}{l}\text { Cultura = basicamente } \\
\text { um sistema de } \\
\text { símbolos }\end{array}$} & $\begin{array}{l}\text { C. Geertz } \\
(1973)\end{array}$ & \multirow{2}{*}{$\begin{array}{l}\text { Combinação de } \\
\text { descrições êmicas e } \\
\text { éticas }\end{array}$} & \multirow{2}{*}{$\begin{array}{l}\text { Símbolos são } \\
\text { envolvidos nos } \\
\text { processos sociais; } \\
\text { eles se tornam } \\
\text { associados aos } \\
\text { interesses, } \\
\text { propósitos, fins e } \\
\text { meios humanos }\end{array}$} \\
\hline & & $\begin{array}{l}\text { V. Turner } \\
(1967)\end{array}$ & & \\
\hline
\end{tabular}

Fonte: Sackamnn, 1991, p.189 
A partir da análise do Quadro 2 adotamos como referência para o presente trabalho a compreensão de cultura exposta por Warnier (2000). O autor mescla as abordagens do materialismo cultural e idealismo cultural, ao afirmar que uma cultura não pode viver ou transmitir-se independentemente da sociedade que a alimenta e, da mesma forma, não há sociedade no mundo que não possua sua própria cultura. Assim, para ele

\begin{abstract}
A cultura é uma totalidade complexa feita de normas, de hábitos, de repertórios de ação e de representação, adquirida pelo homem enquanto membro de uma sociedade. Toda cultura é singular, geograficamente ou socialmente localizada, objeto de expressão discursiva em uma língua dada, fator de identificação dos grupos e dos indivíduos e de diferenciação diante dos outros, bem como fator de orientação dos atores, uns em relação aos outros e em relação ao seu meio. Toda cultura é transmitida por tradições reformuladas em função do contexto histórico. (WARNIER, 2000. P. 23)
\end{abstract}

Essa abordagem congrega, simultaneamente, a singularidade e a diversidade da cultura. Segundo Warnier (2000, p. 17) “A identidade é definida como o conjunto dos repertórios de ação, de língua e de valores que permitem uma pessoa reconhecer sua vinculação a certo grupo social e identificar-se com ele". Ou seja, o autor reforça que a identidade se expressa expressão por comportamentos, relacionamentos e hábitos compartilhados por quem vive em sociedade.

Assim, por estar diretamente conectada aos processos sociais, a cultura é também um dos componentes dos contextos nacional e organizacional. Embora não possa ser definida exclusivamente em função dos valores compartilhados pelos indivíduos que a integram, ela está totalmente relacionada a eles. Aqui, vale destacar a importância desses valores, uma vez que, as principais diferenças culturais entre nações residem nos valores (Hofstede, 1997).

A cultura tem um papel importante na modelação dos valores, atitudes e comportamentos dos indivíduos e membros de diferentes sociedades (Tayeb, apud Ferrari, 2011, p.146), o que nos leva a concluir que "os valores são distintos de sociedade para sociedade e que os diferentes grupos culturais comportam-se de maneira própria sob circunstâncias iguais porque eles valorizam o mesmo objeto de maneira diferente"

Segundo Hofstede (1997), os valores são em sua maioria inconscientes, constituem a preferência por uma determinada coisa em detrimento de outra, e por isso, existem diferenças sistemáticas nos valores referentes ao poder e desigualdade, à relação entre o indivíduo e o grupo, aos papéis sociais do homem e da mulher, às formas de lidar com as incertezas da vida, à atenção diante do futuro, presente ou passado. 
$\mathrm{Na}$ sequência, trataremos mais detalhadamente sobre a importância desses valores na formação da cultura nacional. Com o conceito de cultura delineado, partiremos então para a abordagem referente à cultura nacional e cultura organizacional.

\subsection{Cultura nacional: as dimensões de Hofstede}

Diferentes autores têm desenvolvido diferentes abordagens conceituais e esquemas classificatórios para definir cultura nacional como Adler, 2002; Hall, 1959, 1960, 1977 e Hofstede, 1997, 2001. A maioria dos autores foi influenciado pelo esquema classificatório de cultura elaborado por Hofstede. Entre autores brasileiros Motta e Caldas (1997), Barbosa (1992,) Barbosa e Veloso (2009), Barros e Prates (1996), Tanure (2005) registram que as dimensões culturais de Hofstede têm contribuído para orientar estudos, em função da extensão da escala das pesquisas realizadas por ele e da força das descobertas que permanecem claras e identificáveis até os dias de hoje.

Na década de 1970, Geert Hofstede foi responsável por liderar uma pesquisa com funcionários da empresa IBM em diversos países pelo mundo. A amostra envolveu mais de 160 mil pessoas, sendo que cerca de 70 mil respostas foram utilizadas para comparar resultados entre 40 diferentes países. Apesar de alguns pesquisadores criticarem a defasagem cronológica da pesquisa de Hofstede e dos países pesquisados por ele na época ${ }^{2}$, esse é um dos maiores e mais conhecidos estudos já realizados sobre cultura.

A descoberta mais importante de Hofestede refere-se à importância da cultura nacional na explicação das diferenças em atitudes e valores com relação ao trabalho. Antes dele, outros fatores eram vistos como mais importantes tais como: a posição na organização, profissão, idade ou gênero (Motta e Caldas, 1997).

$\mathrm{Na}$ primeira divulgação dos resultados de sua pesquisa, Hofstede identificou quatro dimensões para as diferentes culturas e países pesquisados, a saber: distância de poder; controle de incertezas, o grau de individualismo (ou de coletivismo); e o grau de masculinidade (ou de feminilidade), que são abordados em detalhes no Quadro 3. Em 1991, Hofstede ampliou seu estudo acrescentando 23 países e atingindo a sociedade oriental, fato

\footnotetext{
${ }^{2} \mathrm{O}$ estudo comparava resultados limitados aos países que, na época, eram economicamente atraentes para a atuação comercial da IBM, excluindo da amostra nações menos desenvolvidas. Estavam excluídos também países de governos comunistas que, no momento da pesquisa, não admitiam operações de multinacionais americanas. Outra crítica diz respeito ao fato da amostra inicial envolver apenas funcionários da IBM, o que não representaria a variedade de trabalhadores e empresas em cada país pesquisado (Hickson and Pugh,1995)
} 
não considerado no primeiro estudo. Nessa segunda pesquisa, Hofstede identificou uma quinta dimensão conhecida como orientação em longo/curto prazo - que representa a visão pragmática e orientada para resultados, traço cultural muito forte na cultura asiática.

Recentemente, o pesquisador incluiu uma sexta dimensão, indulgência X restrição. Indulgência faz referência à "tendência de permitir gratificação de desejos humanos básicos e naturais relativos a gozar a vida e se divertir”. Por outro lado, restrição está relacionada à convicção do indivíduo de que tal gratificação deve ser contida e regulada por normas sociais rigorosas (Hofstede et al. 2010, p.281). Nos dias de hoje, o pesquisador mantém um website ${ }^{3}$ onde publica atualizações da pesquisa e recentes trabalhos divulgados. As dimensões de Hofestede são apresentadas em detalhes no Quadro 3.

\section{Quadro 3: As dimensões de cultura nacional de Hofstede}

\begin{tabular}{|c|c|c|}
\hline \multicolumn{2}{|c|}{ Dimensões } & Descrição \\
\hline Primeira & $\begin{array}{l}\text { Distância de } \\
\text { poder }\end{array}$ & $\begin{array}{l}\text { É o grau em que membros menos poderosos de organizações e } \\
\text { instituições (como a família) aceitam e esperam que o poder seja } \\
\text { distribuído. Representa a desigualdade (mais fortes contra mais fracos) e } \\
\text { sugere que o nível de desigualdade de uma sociedade é endossado tanto } \\
\text { pelos seguidores, quanto pelos líderes. Poder e desigualdade são } \\
\text { claramente fundamentais em qualquer sociedade. Qualquer pessoa com } \\
\text { alguma experiência internacional entende que todas as sociedades são } \\
\text { desiguais, mas algumas são mais desiguais do que outras. }\end{array}$ \\
\hline Segunda & $\begin{array}{l}\text { Controle de } \\
\text { incertezas }\end{array}$ & $\begin{array}{l}\text { Essa dimensão está relacionada à tolerância de uma sociedade para com } \\
\text { a incerteza e a ambiguidade. Ela indica até que ponto uma cultura } \\
\text { programa seus membros a se sentirem desconfortáveis ou confortáveis } \\
\text { em situações não-estruturadas. Essas situações são o que é novo, } \\
\text { desconhecido, surpreendente, diferente do habitual. Culturas que evitam } \\
\text { a incerteza tentam minimizar a ocorrência dessas situações com leis } \\
\text { rígidas e regras. Pessoas em países que controlam a incerteza são mais } \\
\text { emocionais e motivados por uma energia nervosa interior. O tipo oposto, } \\
\text { de culturas que aceitam a incerteza, são mais tolerantes com opiniões } \\
\text { diferentes do que eles estão acostumados, tentam ter o menor número de } \\
\text { regras possíveis e, no nível filosófico e religioso, são relativistas, } \\
\text { permitindo que diferentes crenças convivam lado a lado. }\end{array}$ \\
\hline Terceira & $\begin{array}{c}\text { Individualismo } \\
\mathrm{X} \\
\text { Coletivismo }\end{array}$ & $\begin{array}{l}\text { É o grau em que os indivíduos são integrados em grupos. No lado } \\
\text { individualista, encontram-se sociedades em que os laços entre os } \\
\text { indivíduos são mais frágeis. No lado coletivista, encontramos sociedades } \\
\text { em que as pessoas desde o nascimento estão integradas fortemente em } \\
\text { grupos coesos, com famílias numerosas, que continuam protegendo-os }\end{array}$ \\
\hline
\end{tabular}

\footnotetext{
${ }^{3}$ http://www.geerthofstede.eu
} 


\begin{tabular}{|c|c|c|}
\hline & & $\begin{array}{l}\text { em troca de uma lealdade inquestionável. A palavra coletivismo nesse } \\
\text { sentido não tem nenhum significado político: refere-se ao grupo, e não } \\
\text { ao Estado. Mais uma vez, a questão abordada por esta dimensão é } \\
\text { extremamente fundamental sobre todas as sociedades do mundo. }\end{array}$ \\
\hline Quarta & $\begin{array}{l}\text { Masculinidade } \\
\qquad \mathrm{X} \\
\text { Feminilidade }\end{array}$ & $\begin{array}{l}\text { Refere-se à distribuição de papéis emocionais entre os sexos, que é outra } \\
\text { questão fundamental para qualquer sociedade. Os estudos realizados na } \\
\text { IBM revelaram que: a) os valores das mulheres diferem menos entre as } \\
\text { sociedades do que os valores dos homens; b) de um país para outro, os } \\
\text { valores dos homens variam entre muito assertivo e competitivo, o que } \\
\text { por um lado é diferente dos valores das mulheres, e por outro lado, } \\
\text { variam entre modéstia e carinho, que são semelhantes aos valores das } \\
\text { mulheres. O pólo da assertividade tem sido chamado de masculino e o } \\
\text { pólo da modéstia/cuidando é chamado de feminino. Nos países mais } \\
\text { femininos, as mulheres apresentam os mesmos valores que os homens. } \\
\text { Já nos países mais masculinos, elas são mais assertivos e mais } \\
\text { competitivas, mas não tanto quanto os homens, por isso estes países } \\
\text { apresentam uma diferença entre os valores dos homens e das mulheres. }\end{array}$ \\
\hline Quinta & $\begin{array}{l}\text { Orientação em } \\
\text { longo/curto } \\
\text { prazo }\end{array}$ & $\begin{array}{l}\text { Dimensão incluída em 1991, a partir de pesquisa realizada por Michael } \\
\text { Bond e seus colegas. Em 2010, nova pesquisa realizada por Michael } \\
\text { Minkov (World Values Survey) estendeu o número de países analisados } \\
\text { para 93. Sociedades orientadas a longo prazo tendem a promover } \\
\text { virtudes pragmáticas, orientadas para recompensas futuras, tais como: } \\
\text { economia, persistência e adaptação a novas circunstâncias. Sociedades } \\
\text { orientadas a curto prazo adotam virtudes relacionadas ao passado e ao } \\
\text { presente, tais como: como orgulho nacional, respeito pela tradição, a } \\
\text { preservação do contato pessoal e do cumprimento de obrigações sociais. }\end{array}$ \\
\hline Sexta & $\begin{array}{l}\text { Satisfação } \\
\quad X \\
\text { Restrição }\end{array}$ & $\begin{array}{l}\text { Na mesma pesquisa realizada por Minkov em } 93 \text { países foi identificada } \\
\text { essa nova dimensão. Sociedades marcadas pela satisfação permitem } \\
\text { gratificações relativamente livres de necessidades básicas humanas, tais } \\
\text { como aproveitar a vida e se divertir. Sociedades marcadas pela restrição } \\
\text { oprimem a satisfação dessas necessidades e são reguladas por meio de } \\
\text { normas sociais mais rígidas. }\end{array}$ \\
\hline
\end{tabular}

Fonte: Geert Hofstede (2015)

Segundo Hofstede, as dimensões descritas no Quadro 3 são utilizadas para distinguir os países pesquisados e suas respectivas culturas e não os indivíduos. Por isso, eles foram agrupados em quatro temas que Hofstede (1997) identificou como problemáticas antropológicas que as diferentes sociedades têm de lidar, também de forma diferente. Essas dimensões, como próprio Hofstede descreveu, determinam as maneiras como as culturas nacionais enfrentam a desigualdade, a incerteza, a relação do indivíduo com a sociedade ou com seu grupo principal.

Como o próprio Hofstede $(1997,2001)$ registra em suas publicações, as dimensões 'distância de poder' e 'controle de incertezas' são elevadas em culturas de países latinos. Entre os 
resultados gerais encontrados, Hofstede destaca ainda que culturas dos países Asiáticos e Africanos também têm pontuação alta para distância de poder, enquanto culturas Germânicas e Inglesas têm distância de poder baixas. O controle de incertezas também é alto no Japão e em países de língua alemã, e é baixo entre os Ingleses, Nórdicos e Chineses. O individualismo prevalece em países ocidentais mais desenvolvidos, enquanto o coletivismo é maior nos menos desenvolvidos e orientais. O Japão fica em uma posição mediana nessa dimensão.

A masculinidade é alta no Japão e em alguns países europeus, como a Alemanha, Áustria e Suíça, mas é baixa nos países Nórdicos e na Holanda e moderadamente baixa em alguns países de língua latina e da Ásia, como França, Espanha e Tailândia. As pontuações de orientação de longo prazo são mais altas na Ásia Oriental e baixas no mundo muçulmano, América Latina e África. Para satisfação, as pontuações são mais altas na América Latina, partes da África e Europa Nórdica; enquanto um nível alto de restrição é encontrado principalmente no leste da Ásia, Europa Oriental e do mundo muçulmano.

O modelo de Hofstede definindo dimensões da cultura nacional tem sido aplicado na prática em vários setores da sociedade, nos negócios, na educação e na saúde. De acordo com o Web of Science $^{4}$, em 2008, havia mais de 800 artigos publicados em revistas científicas citando uma ou mais de uma das publicações de Geert Hofstede. Os maiores interesses estão nas aplicações para a área de marketing, publicidade e comportamento do consumidor.

Para o autor, existe uma relação estreita entre a cultura nacional e a cultura organizacional, sendo que a primeira exerce um papel vital sobre a segunda: "A cultura nacional tem um impacto profundo nas organizações, com repercussões nos negócios e nos governos" (Hofstede, 1997. p. 272). Ele é incisivo ao afirmar que há um impacto da cultura nacional nas práticas gerenciais e nas atitudes e valores em relação ao trabalho, mas distingue as duas abordagens destacando que as culturas nacionais pertencem à antropologia e as culturas organizacionais à sociologia. Segundo Hofstede, as culturas organizacionais são menos a expressão de valores que formam o núcleo das culturas nacionais e mais as manifestações superficiais como símbolos, heróis e rituais. Assim, para abordar as culturas organizacionais, nos apoiaremos na referência de Edgar Schein, como se segue.

\footnotetext{
${ }^{4}$ Uma das bases de dados de literatura técnico-científica internacionais mais consultadas em relação ao fator de impacto.
} 


\subsection{Cultura Organizacional: o olhar de Schein}

O uso do termo 'cultura' no contexto dos negócios ocorreu a partir de meados da Segunda Guerra Mundial em diante, principalmente nos Estados Unidos, e está historicamente relacionada à preparação de diplomatas e homens de negócios norte-americanos para trabalharem no exterior (Hall, 1959; Benedict, 1972).

A cultura se tornou foco das discussões no âmbito das organizações durante a década de 80 e o início da década de 90, quando os teóricos organizacionais ocidentais se interessaram mais pelo desenvolvimento da cultura de seus países e pelas ligações entre cultura e comportamentos organizacionais (Morgan, 1997). Hilal (2003) registra que alguns teóricos como (Pascale e Ouchi, 1981) notaram que a cultura nacional não fornecia uma explicação suficiente para o contexto organizacional. Assim, entre os fundadores dos estudos sobre cultura corporativa, Hilal (2003) cita Peters \& Walterman (1982) e Deal \& Kennedy (1982).

O arcabouço conceitual da cultura organizacional tem suas raízes em várias das Ciências Sociais como a Antropologia, a Sociologia, a Psicologia Social, assim como no estudo do comportamento organizacional (Hilal, 2003). Chester Barnand, nos anos 1930 e 40 e Peter Drucker nos anos 50 já consideravam a centralidade de valores culturais na administração das organizações. Os referidos autores acreditavam que o gerenciamento de organizações significava mais do que uma simples tomada de decisão e procedimentos de planejamento.

Para fins comparativos dos diversos enfoques existentes para o tema da cultura organizacional, serão apresentados a seguir alguns conceitos e autores que pareceram ser mais significativos. Essa seleção não esgota o assunto e não tem a pretensão de privilegiar determinadas abordagens; apenas tem o objetivo de demonstrar a amplitude do tema que está em foco. Com esse propósito, merece destaque a perspectiva de Schall (1983), que parece ter um viés para a área de comunicação, ao afirmar que:

(...) uma organização poderia, então, ser estudada como uma cultura, descobrindose e sintetizando suas regras de interação e interpretações sociais, como reveladas no comportamento que elas moldam. A interpretação e interação social são atividades de comunicação, portanto, a cultura poderia ser descrita pela articulação de regras de comunicação. (SCHALL, 1983, p. 146)

Por sua vez, Freitas (1991, p. 34) afirma que as culturas são criadas, sustentadas, transmitidas e mudadas através da interação social, que na empresa se expressa por meio de papéis informais na rede de comunicação. Essa rede faz a amarração das diversas partes da 
organização, transmitindo informações e interpretando os significados das informações para os outros envolvidos. Para a autora, as organizações devem ser vistas como "fenômenos de comunicação", no qual o processo de comunicação ajuda a criar a cultura organizacional. Essa visão traz uma interpretação multidisciplinar à cultura organizacional, que influencia e é influenciada por outras práticas sociais. A comunicação também é mencionada na definição de Fleury e Fischer (1989) para cultura organizacional:

(...) um conjunto de valores e pressupostos básicos expresso em elementos simbólicos, que, em sua capacidade de ordenar, atribuir significados e construir a identidade organizacional, tanto agem como elemento de comunicação e consenso como ocultam e instrumentalizam as relações de dominação. (FLEURY E FISHER, 1989, p. 22)

A perspectiva de Fleury e Fisher (1989) agrega simbologias e relações de poder ao contexto da cultura organizacional. Nessa mesma linha, Morgan (1986, p. 43) considera a cultura organizacional como uma metáfora: "a metáfora de cultura aponta para um outro meio de criar uma atividade organizada: influenciando a linguagem, as normas, o folclore, as cerimônias e outras práticas sociais que transmitem as ideologias, os valores e crenças principais, guiando a ação".

A concepção de cultura organizacional como um conjunto de comportamentos e características cognitivas é descrita por Eldrigde e Crombie (1974):

(...) a cultura de uma organização refere-se à configuração singular de normas, valores crenças, modos de se comportar e outros elementos que caracterizam a maneira pela qual os grupos e indivíduos se combinam para realizar as coisas. A distinção de determinada organização está intimamente ligada com sua história e com os efeitos de caracterização de decisões e líderes do passado. Ela é manifestada de modo folclórico, e mais ainda, na ideologia que difere os membros, assim como nas escolhas estratégicas feitas pela organização como um todo. (ELDRIDGE E CROMBIE, 1974, p. 89)

Após avaliar essas e outras definições ao longo da pesquisa bibliográfica, pode-se entender que os estudos sobre cultura organizacional tendem a agrupá-las de duas formas: a) como uma metáfora, considerando cultura algo que a organização é; b) como uma variável, considerando a cultura algo que a organização tem. Entender a organização como uma cultura é reconhecer o papel ativo dos indivíduos na construção da realidade organizacional e no desenvolvimento de interpretações compartilhadas para sua experiência (Freitas, 2007).

De acordo com Schein (1992), a cultura de uma organização é a aprendizagem compartilhada e acumulada de um grupo, cobrindo elementos comportamentais, cognitivos e emocionais do 
funcionamento psicológico dos membros desse grupo. Ele afirma que a cultura organizacional é algo dinâmico, intangível, uma construção social coletiva, resultante da interação de pessoas e grupos em unidades sociais estáveis. Por isso, a empresa é um espaço sociocultural, que tem sua dimensão mais profunda nas premissas culturais que suportam as atitudes e os comportamentos das pessoas neste ambiente.

Apesar de o tema ser abordado por diversos autores, como demonstrado anteriormente, o arcabouço mais representativo de cultura organizacional é o de Schein, sendo reconhecido como um dos autores mais influentes sobre o tema (Schultz, 1995). Schein (1985, 1987, 1992, 2009) foi um dos primeiros pesquisadores organizacionais a sugerir a importância da cultura no contexto organizacional e é referência mundial nesse assunto. Seus trabalhos são enquadrados na abordagem funcionalista e estão baseados em entrevistas, apoiando-se em teorias psicológicas da conformação psicodinâmica dos líderes para descrever como as organizações começam a criar culturas por meio das ações de seus fundadores, tomando como pressuposto o fato de que a cultura e a liderança são duas faces da mesma moeda.

Segundo Hilal (2003), Schein acreditava que a compreensão da cultura organizacional era tão crítica para o sucesso do líder que talvez a única coisa realmente importante que os líderes pudessem realizar era criar e gerenciar a cultura. Schein $(1985,1987,1992,2009)$ estuda a cultura organizacional desde 1981 e apresenta um dos conceitos mais ricos na literatura consultada:

\begin{abstract}
A cultura organizacional é o modelo dos pressupostos básicos, que determinado grupo tem inventado, descoberto ou desenvolvido no processo de aprendizagem para lidar com os problemas de adaptação externa integração interna. Uma vez que os pressupostos tenham funcionado bem o suficiente para serem considerados válidos, são ensinados aos demais membros como a maneira correta para se perceber, se pensar e sentir-se em relação àqueles problemas (SCHEIN, 1985, p.4)
\end{abstract}

Percebemos nessa definição a preocupação de ir além dos comportamentos observáveis, pois para se interpretar a cultura de uma organização é preciso ir além dos artefatos visíveis e descobrir os pressupostos básicos, que são o centro da cultura organizacional (Schein, 1997). Esses elementos - pressupostos básicos, artefatos visíveis e outros conjuntos simbólicos, como valores - formam as culturas nacionais, subculturas, assim como culturas organizacionais e permitem analisá-las. De acordo com o Quadro 4, Schein subdivide a cultura em três níveis. 
Quadro 4: Níveis de cultura organizacional, segundo Schein

\begin{tabular}{|c|c|c|}
\hline $\begin{array}{l}\text { Artefatos e Criações } \\
\text { (processos e estruturas } \\
\text { visíveis) }\end{array}$ & $\begin{array}{ll}\text { - } & \text { Modelos de comportamento } \\
\text { - } & \text { Tecnologia } \\
\text { - } & \text { Arte }\end{array}$ & $\begin{array}{l}\text { Visíveis, mas } \\
\text { frequentemente não } \\
\text { decifráveis }\end{array}$ \\
\hline $\begin{array}{l}\text { Valores } \\
\text { (estratégias, objetivos, } \\
\text { filosofias) }\end{array}$ & $\begin{array}{ll}- & \text { Testado no ambiente físico } \\
\text { - Testado somente por consenso } \\
\text { social }\end{array}$ & $\begin{array}{l}\text { Conscientes, em alto grau. } \\
\text { Excelente nível de } \\
\text { conhecimento }\end{array}$ \\
\hline $\begin{array}{l}\text { Pressupostos básicos } \\
\text { (inconsciente, crenças } \\
\text { estabelecidas, percepções, } \\
\text { reflexos e sentimentos) }\end{array}$ & $\begin{array}{l}\text { - } \quad \text { Relacionamento com o ambiente } \\
\text { - Natureza da realidade } \\
\text { - } \quad \text { Tempo e espaço } \\
\text { - Natureza da natureza humana } \\
\text { - Natureza das relações humanas }\end{array}$ & $\begin{array}{l}\text { Considerados como } \\
\text { verdadeiros. Invisível } \\
\text { Inconsciente }\end{array}$ \\
\hline
\end{tabular}

Fonte: Schein, 1997, p. 76

Para Schein (1997), os níveis da cultura organizacional têm caráter hierárquico, uma vez que, ao se modificar os artefatos, estes alteram os valores em longo prazo podem vir a modificar os pressupostos (Ferrari, 2011). Enquanto os pressupostos básicos são pré-conscientes e tidos como certos, os valores exigem um pouco mais de tempo para serem percebidos, mas são conscientes, ao contrário do que diz Hofstede (1997). Nas organizações, esses valores contribuem para criar parâmetros de como pensar, sentir e agir, por isso desempenham papel fundamental para o sucesso das empresas. Nesse sentido, é possível apreender que as organizações são parte de uma sociedade e, consequentemente, parte de sua cultura:

(...) as representações e comportamentos emanados de valores, crenças e mitos valorizados na cultura de uma organização são reforçados e formados dialeticamente com suas estruturas formais, suas inter-relações vividas em seu diaa-dia e tudo aquilo de concreto que compõe o mundo material da organização. Por sua vez, tais elementos materiais organizacionais estão profundamente enraizados na história e na formação etnológica da cultura nacional que os engendram. (FREITAS, 2007, p. 41)

A citação deixa claro que as organizações são subculturas de uma sociedade e, por isso, a cultura nacional pode ser considerada como fonte de sustentação, que oferece referências e direciona comportamentos, como diz Tanure (2005, p. 23): “(...) a empresa é ume espaço sociocultural. A cultura nacional é um dos pilares da cultura organizacional. Obviamente não é o único." Motta e Caldas (1997, p. 41) reforçam esse ponto de vista indicando que cada organização delimita uma cultura organizacional gerada e sustentada pelos mais diversos 
elementos e formas e que nesse quadro, "a cultura nacional é um dos fatores na formação da cultura organizacional e sua influência pode variar de organização para organização".

Ferrari (2011) também reconhece a relação próxima entre cultura organizacional e cultura nacional ao expressar que a análise da cultura organizacional pressupõe também a análise do ambiente externo, seja do contexto da comunidade local, regional, nacional, continental ou globalizada e reforça a importância de se analisar a cultura como um sistema de símbolos e significados compartilhados, que servem como mecanismo de controle e influi no comportamento organizacional. Em seu estudo comparativo entre organizações chilenas e brasileiras observou como a cultura nacional afeta a maneira pela qual as pessoas se comportam no ambiente organizacional e, consequentemente, afeta o processo da comunicação entre os seus membros (Ferrari, 2000).

Sendo assim, a seguir, abordaremos a cultura organizacional, com o objetivo de identificar como as empresas estão lidando com essa nova forma de gerir seus negócios, agregando processos e perspectivas para dar conta dessa nova realidade organizacional.

\subsection{O desafio da gestão intercultural nas organizações}

Trabalhar em e com equipes multiculturais e operar mercados culturalmente diversos passou a ser parte do cotidiano organizacional, além de se configurar como um diferencial competitivo para jovens gerentes e uma exigência básica para qualquer líder organizacional. No momento em que a economia se torna cada vez mais global e o impacto dos avanços da tecnologia da informação está cada vez mais presente no cotidiano, as empresas devem ter visão ampla dos aspectos multiculturais que impactam a sociedade (Tanure, 2005).

Independentemente de onde uma empresa estiver localizada, alguns de seus desafios neste século são comuns a qualquer outra empresa na mesma região ou país: redução de custos, reformulação de estruturas organizacionais e implantação de sistemas para garantir condições básicas para a competitividade são alguns exemplos desses desafios. Para Tanure (2005, p. 22), o que difere uma empresa de outra é a metodologia utilizada para enfrentar esses desafios, com interpretações, palavras e significados distintos, portanto. Segundo a autora, "a competência cross-cultural está se tornando cada vez mais um atributo fundamental para a 
gestão, pois se transforma em mais um dos parâmetros relevantes para a performance e sobrevivência do negócio".

A fim de descrever e caracterizar o momento que confere dinâmica própria e uma nova singularidade ao ambiente organizacional, Finuras (2007), destaca cinco novos fatos marcantes desse cenário cross-cultural:

- a existência de novos atores, que são as organizações, associações e blocos comerciais (União Européia, Mercosul, União Africana, entre outros), formados a partir de sociedades para produzir e comercializar de forma integrada;

- novos mercados, delineados a partir do crescimento e desenvolvimento das economias, interligando centros empresariais e financeiros, espalhados pelo mundo, interagindo 24 horas por dia, à distância, e favorecendo uma onda de fusões, aquisições e a criação de marcas e mercados em escala global;

- novas regras e normas, que envolvem novas políticas econômicas de mercado, com maior privatização e liberalização, com leis específicas para ampliar ainda mais os acordos multilaterais;

- novos instrumentos de comunicação, como a internet e as tecnologias de transmissão de dados, que permitem conectar pessoas, empresas, nações, independentemente do tempo, espaço e localização geográfica, afetando de forma intensa e profunda suas vidas cotidianas; e

- novos paradigmas de gestão, que surgem a partir da falência dos paradigmas clássicos, tais como a passagem da especialização para a transversalidade, da centralização para a descentralização, e do auto-controle para o hetero-controle (esse último ilustra os processos de transnacionalização de empresas e a necessidade de atuação multidoméstica com unidades autônomas).

É neste ambiente, que a mobilidade e a interculturalidade despontam como valores-chave na gestão das organizações. O Quadro 5 apresenta algumas características dessa movimentação. 


\section{Quadro 5: Características das organizações em ambientes interculturais}

\begin{tabular}{|c|c|}
\hline Dimensão coletiva & Dimensão individual \\
\hline $\begin{array}{l}\text { Formação de um ambiente de trabalho } \\
\text { cada vez mais qualificado, heterogêneo e } \\
\text { com maior potencial de conflitos }\end{array}$ & $\begin{array}{l}\text { Urgência no desenvolvimento de maiores } \\
\text { competências comunicativas e de } \\
\text { negociação }\end{array}$ \\
\hline $\begin{array}{l}\text { Desenvolvimento de novas formas de } \\
\text { sinergia estratégica e de incessantes } \\
\text { incorporações tecnológicas }\end{array}$ & $\begin{array}{l}\text { Necessidade de habilidades para a } \\
\text { coordenação de equipes multiculturais e } \\
\text { multidisciplinares }\end{array}$ \\
\hline $\begin{array}{lrr}\text { Revisão de processos } & \text { produtivos, } \\
\text { financeiros, administrativos } & \end{array}$ & $\begin{array}{l}\text { Desenvolvimento de uma mentalidade } \\
\text { intercultural. }\end{array}$ \\
\hline
\end{tabular}

Fonte: Adaptado de Freitas, 2008, p. 101

O Quadro 5 nos mostra que existem duas dimensões nesse novo ambiente de gestão intercultural; uma que envolve o indivíduo/funcionário e outra a empresa/organização. $\mathrm{Na}$ dimensão individual são solicitadas competências e habilidades para que os executivos possam se integrar e atuar nas organizações. Na dimensão coletiva são consideradas estruturas e processos que foram incorporadas a partir da necessidade de se destacar, competir e rentabilizar o negócio.

Todo esse conjunto de competências e habilidades vem sendo descrito por alguns autores como "global mindset" ou mentalidade global. Trata-se da consciência da diversidade entre culturas e mercados, aliada à capacidade de perceber pontos comuns e oportunidades onde existe complexidade e múltiplas realidades culturais. É a capacidade de apreciar, valorizar e gerenciar a diversidade humana e cultural, administrando processos de mudanças e visionando cenários mais amplos. A organização ou o líder com "global mindset" se caracterizam pela abertura para mediar e integrar a multiplicidade, tomando decisões que funcionam tanto localmente, quanto globalmente, aprimorando a competitividade do negócio no mercado internacional.

Gupta e Govindarajan (2002) argumentam que o "global mindset" é um dos ingredientes que formam a inteligência organizacional necessária para identificar e explorar oportunidades, mesmo que em regiões distantes e diferentes. Segundo os autores, nos negócios globalizados é requerido que os gestores sejam capazes de transitar por culturas e mercados altamente heterogêneos, percebendo-os e interpretando-os. 
Reis (2012) afirma que essa mentalidade global ou "global mindset" está presente em maior grau em empresas que passaram por processos de internacionalização, o que acaba por contribuir não apenas para o desenvolvimento de competências para negócios internacionais, como também para uma maior exposição internacional. O pesquisador detectou que a orientação global, aliada ao conhecimento e a habilidades também globais, geram comprometimento e foco em relação à internacionalização, capacidade de reconhecer oportunidades globais e de desenvolver rede de negócios internacionais.

Portanto, para obter sucesso sustentável nesse ambiente, não basta mais que os executores das políticas organizacionais das empresas sejam dotados de liderança, facilidade de articulação, percepção aguçada, capacidade de desenvolver habilidades específicas e vasto arsenal de conhecimentos e qualificações. Tanure, Cyrino e Penido (2007, p. 212) argumentam que os executivos também precisam "ser capazes de apreciar, valorizar e gerenciar a diversidade humana e cultural. Devem saber administrar processos de mudança e enxergar cenários mais amplos com a habilidade de identificar mercados e competidores potenciais e novas fontes de recursos". Tudo isso, também se resume no conceito de global mindset e determina a capacidade de realizar ou não a gestão intercultural.

Para Alvarez (2009), essas habilidades constituem o que ela denomina de 'competência intercultural', ou uma resposta aos requerimentos de uma função específica em uma organização intercultural. Para a autora, uma pessoa com competência intercultural poderá analisar e desenvolver melhores estratégias de localização, acesso e integração de empresas de culturas diferentes, pois ela conhece e compreende os elementos e condutas que mais se adéquam a cada situação cultural. Entre os componentes dessa competência estão a transversalidade, a consideração de aspectos mais individuais e subjetivos de cada pessoa, a influência do contexto e, o que aqui, especificamente, nos interessa focalizar - a comunicação. Para Finuras (2007),

Os gestores e executivos de empresas globais são responsáveis não apenas por delinear estratégias e táticas para alcançar os objetivos organizacionais, mas precisar pensar sistemática e abertamente nas organizações como culturas, que têm de mudar e adaptar-se para sobreviver. (FINURAS, 2007, p. 52)

Assim, torna-se cada vez mais clara a importância da gestão intercultural e dos estudos organizacionais interculturais, enquanto aspectos indispensáveis na gestão contemporânea. Freitas (2008) registra que é exatamente esta convivência intercultural que vem sendo 
reconhecida como uma vantagem a ser explorada no mundo dos negócios. E Hilal (2003) complementa, ponderando que, em uma época de organizações multinacionais e de globalização, a compreensão do impacto das interações culturais pode influenciar diretamente o sucesso e talvez a sobrevivência organizacional.

A cultura é um dos elementos básicos da organização, de alta relevância para o sucesso ou fracasso das operações de empresas que se propõem a atuar em um ambiente global. No momento em que a globalização e a multinacionalização de empresas não é mais uma tendência, mas sim um movimento constante, a influência da cultura é proporcionalmente maior. Por isso, na sequência, vamos abordar uma tipologia de cultura organizacional, proposta por Cameron e Quinn (2006).

\subsection{Tipos de cultura organizacional, segundo Cameron e Quinn}

Como vimos, nos últimos anos, muitos autores se dedicaram a tratar das diversas dimensões e atributos da cultura organizacional. Uma das razões para que tantas dimensões terem sido propostas pode estar no fato de que o tema da cultura organizacional é extremamente amplo e inclusivo. Ela compreende fatores complexos, ambíguos e ao mesmo tempo abrangentes. Mirando o objetivo deste trabalho e o contexto de análise a que nos propusemos, até aqui, focalizamos nossos estudos nas teorias de Schein $(1992,2009)$ e Hofstede (1980).

Entretanto, para embasar a análise da pesquisa realizada neste trabalho, era preciso determinar dimensões que oferecessem fundamento e, ao mesmo tempo, fossem validadas e referendadas por outras pesquisas. Assim, encontramos a proposta de tipologia de Cameron e Quinn (2006), que, por ser baseada em evidências empíricas, oferece instrumentos já validados para diagnosticar a cultura organizacional e um arcabouço teórico sólido para compreender a cultura organizacional.

Os autores acreditam que existam muitos tipos ou níveis de cultura que afetem tanto o comportamento do indivíduo quanto da organização. Como já apontamos ao descrever o trabalho de Hofstede (1980), há diferenças culturais entre continentes e países, de acordo com algumas dimensões. Por outro lado, como vimos, em geral, a cultura é refletida pela linguagem única, símbolos e regras. Já a cultura de uma organização é refletida pelo que é 
valorizado, pelos estilos de liderança dominantes, pelos procedimentos e rotinas, e ainda pelas definições de sucesso que tornam únicos cada equipe/departamento de uma empresa.

Cameron e Quinn (2006) criaram um método para diagnosticar tipos de cultura organizacional que captura as principais dimensões da cultura, que efetivamente fazem a diferença no dia a dia das organizações. Tudo começou quando Quinn e Rorbaugh (1981) desenvolveram um modelo, conhecido por "Modelo de Valores Competitivos", que buscava entender e medir a eficácia organizacional. Esse modelo foi testado por diversas vezes e sua aplicação se estendeu a outros estudos, incluindo o estudo de análise da cultura organizacional.

Este modelo parte do princípio que as organizações podem ser caracterizadas de acordo com seus traços comuns e, assim, interpreta seus atributos e estuda a cultura em termos comparativos para definir os tipos de cultura organizacional. Para detalhar as diferenças de valores que norteiam os padrões de eficácia organizacional, o "Modelo de Valores Competitivos" apresenta quatro grupos de valores organizacionais, que representam suposições básicas opostas ou que competem entre si continuamente. Cada um desses valores está representando em um quadrante, conforme representando na Figura 1.

\section{Figura 1: Modelo de Valores Competitivos}

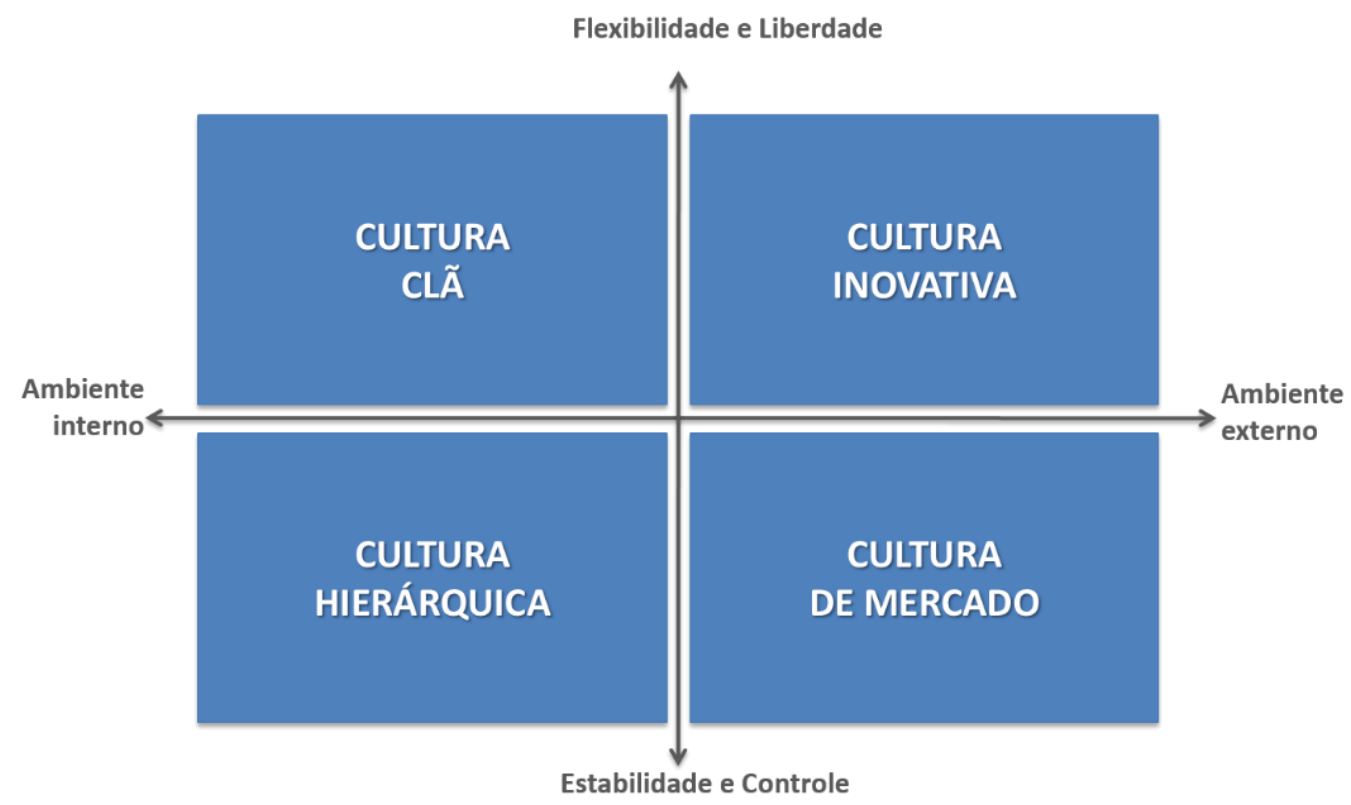

Fonte: Cameron e Quinn (2006, p.50) 
No eixo vertical, enquanto uma das dimensões destaca flexibilidade e dinamismo, a outra enfatiza estabilidade, ordem e controle. Isto é, algumas organizações são vistas como eficientes por serem abertas às mudanças, adaptáveis e orgânicas, como é o caso de empresas de tecnologia, por exemplo. Já outras organizações são percebidas como eficientes se mantiverem estáveis e previsíveis, como é o caso de universidades, construtoras ou empresas de bens duráveis. No eixo horizontal, as dimensões enfocam como critério a orientação para o ambiente externo, o mercado, a competitividade, ou para o ambiente interno, destacando harmonia e sinergias.

Juntas, essas dimensões formam quatro quadrantes, cada um representando um indicador que marca a principal característica da organização e representa o que as pessoas avaliam sobre a performance ou efetividade dela. Esses indicadores podem ser chamados também de "valores fundamentais" e, da forma como estão localizados na matriz, se mostram como opostos uns aos outros. Por exemplo, o quadrante superior esquerdo representa valores que enfatizam ambiente interno e adaptável à mudanças. Por outro lado, o quadrante inferior direito enfoca o ambiente interno, de alta estabilidade e controle.

Em cada um dos quadrantes, foi dado um nome da característica mais representativa da cultura: clã, inovativa, hierárquica e de mercado. Os autores explicam que, devido à robustez das dimensões e à riqueza das informações sobre cada quadrante, eles identificaram que se tratavam de tipos diferentes de cultura, que caracterizavam as organizações e representavam suas premissas, orientações e valores. Exatamente o que compreende a cultura organizacional. Por se tratar de um modelo validado e já utilizado em outras pesquisas, será utilizado como matriz de análise dos resultados da pesquisa deste trabalho (ver detalhes no capítulo sobre metodologia).

Para facilitar o entendimento da tipologia mencionada, apresentamos no Quadro 6 o descritivo e os respectivos tipos de cultura organizacional, que foram desenvolvidos por Cameron e Quinn (2006).

\section{Quadro 6: Os quatro principais tipos de cultura organizacional}

\begin{tabular}{|c|l|l|}
\hline Tipo & \multicolumn{1}{|c|}{ Descrição } & \multicolumn{1}{|c|}{ Exemplo } \\
\hline Cultura & Esta cultura é permeada por pressupostos de estabilidade e & Empresas \\
Hierárquica & reflete os valores e normas associados à burocracia. Os & públicas e e \\
\hline
\end{tabular}




\begin{tabular}{|c|c|c|}
\hline & $\begin{array}{l}\text { empregados aceitam bem a autoridade que emana de papeis } \\
\text { formalmente estabelecidos, de regras e regulamentos } \\
\text { impostos. Os fatores de motivação incluem segurança e } \\
\text { ordem. Os líderes tendem a ser conservadores em relação aos } \\
\text { problemas de natureza técnica. Tem origem nos estudos do } \\
\text { sociologista Max Weber, sobre organizações governamentais } \\
\text { no início dos anos 1900, na Europa. }\end{array}$ & $\begin{array}{l}\text { agências de } \\
\text { governo. }\end{array}$ \\
\hline $\begin{array}{l}\text { Cultura de } \\
\text { Mercado }\end{array}$ & $\begin{array}{l}\text { Tem como orientação tendências de mercado e bases seguras } \\
\text { de clientes. Os fatores de motivação incluem competição e } \\
\text { consecução de resultados preestabelecidos. Os líderes tendem } \\
\text { a ser diretivos, realizadores, competidores, orientados para o } \\
\text { objetivo e estão constantemente fornecendo recursos e } \\
\text { encorajando a produtividade. São severos e exigentes. O } \\
\text { elemento que fundamenta a organização é a ênfase no } \\
\text { vencedor. }\end{array}$ & $\begin{array}{l}\text { Empresas de } \\
\text { bens de } \\
\text { consumo e } \\
\text { tecnologia. }\end{array}$ \\
\hline Cultura Clã & $\begin{array}{l}\text { Enfatiza o desenvolvimento das pessoas e valoriza a } \\
\text { participação nas tomadas de decisões. A autoridade flui } \\
\text { muito bem quando emana de membros comprometidos com o } \\
\text { sistema há muito tempo. Os líderes tendem a assumir uma } \\
\text { postura participativa, oferecendo suporte e facilitando a } \\
\text { interação, a confiança e a lealdade. }\end{array}$ & $\begin{array}{l}\text { Empresas } \\
\text { familiares, } \\
\text { com figura } \\
\text { paternalista } \\
\text { forte. }\end{array}$ \\
\hline $\begin{array}{l}\text { Cultura } \\
\text { Inovativa }\end{array}$ & $\begin{array}{l}\text { É permeada por pressupostos de mudança e flexibilidade. Os } \\
\text { fatores de motivação incluem crescimento, estímulo, } \\
\text { diversificação e criatividade na tarefa. Os lideres tendem a se } \\
\text { empreendedores e idealistas. Apreciam correr riscos, gostam } \\
\text { de prever o futuro e também se preocupam em obter recursos, } \\
\text { suporte e imagem externa. A ênfase está voltada para a } \\
\text { aquisição de novos conhecimentos em produtos e/ou } \\
\text { serviços. }\end{array}$ & $\begin{array}{l}\text { Empresas } \\
\text { ligadas ao } \\
\text { mercado de } \\
\text { comunicação, } \\
\text { tecnologia, } \\
\text { saúde ou } \\
\text { serviços. }\end{array}$ \\
\hline
\end{tabular}

Fonte: A autora, adaptado de Cameron e Quinn (2006, p. 52) e Barreto, Kishore e Reis (2013, p. 36).

Apesar de muitas vezes não ser possível classificar ou tipificar as organizações totalmente em um ou outro quadrante, Cameron e Quinn (2006) descobriram durante suas pesquisas que a maior parte das organizações desenvolve um estilo cultural dominante. Mesmo que tenham estilos culturais diferentes coexistindo, de forma geral, em toda a organização, eles afirmam 
que mais de $80 \%$ de milhares de empresas que estudaram foram caracterizadas por um desses tipos. Nos casos extremos, em que não é possível identificar um tipo de cultura dominante, as características também não ficam muito claras e o peso em cada um dos quatro tipos de cultura chega a ficar quase igual.

Considerando que o foco do presente trabalho são empresas brasileiras, faremos a seguir a apresentação de um recorte sobre as características e traços culturais de organizações brasileiras, com base nos estudos de Tanure (2005, 2009) e Barros e Prates (1996).

\subsection{Traços culturais brasileiros: características definidas por Tanure}

Após nos dedicarmos aos conceitos de cultura, cultura nacional e cultura organizacional, vamos tratar das especificidades das organizações brasileiras e suas características culturais mais marcantes. O objetivo é apresentar o modelo proposto por Barros e Prates (1996) e Tanure (2005, 2009), chamado de Modelo de Ação Cultural Brasileira e sua influência sobre a gestão. Dessa forma, pretendemos contextualizar nosso objeto de estudo: as organizações brasileiras e a cultura que permeia seus processos e atividades.

O Modelo de Ação Cultural Brasileira, proposto por Barros e Prates (1996) foi desenvolvido na década de 90, a partir de pesquisa realizada com mais de 2.500 executivos brasileiros e é composto de quatro sistemas: o institucional (formal), o pessoal (informal) o dos líderes e dos liderados. O sistema institucional está relacionado aos traços culturais percebidos no contexto externo da empresa. Já o pessoal se refere aos traços individuais, próprios de cada grupo ou indivíduo. No sistema dos Líderes, apresenta-se os traços encontrados entre os que representam o poder e, no sistema dos Liderados estão aspectos culturais mais próximos dos subordinados ao poder.

Tanure (2009) observa que se trata de uma visão dinâmica e relativa, uma vez que as características podem ser encontradas de acordo com cada situação, dependendo da posição do indivíduo na organização: seja ele líder ou liderado; ou ainda do momento de atuação: pessoal ou impessoal. Outro ponto importante a destacar é que as configurações dos traços culturais podem gerar sobreposição, variações, predomínio, hegemonia de uma sobre a outra, 
ou até a simples convivência entre elas. Quando ocorre interseções entre os sistemas, encontra-se traços culturais comuns, conforme pode ser visto na Figura 2.

\section{Figura 2: Visão integrada do Modelo de Ação Cultura}

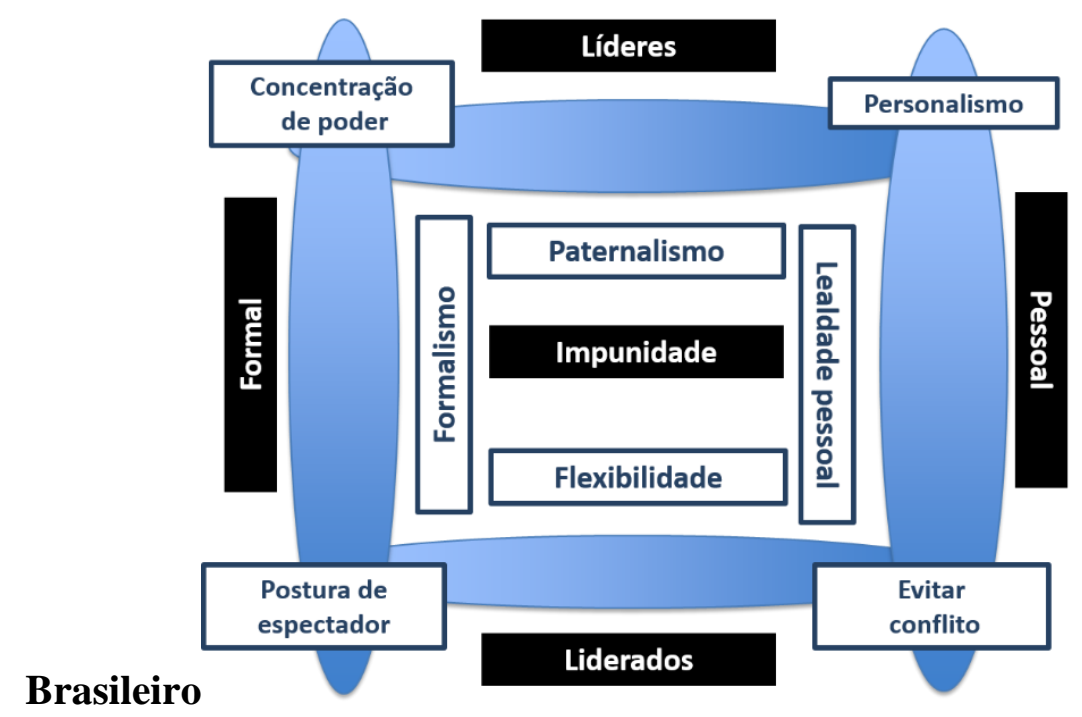

Fonte: Tanure $(2009$, p. 36)

A Figura 2 mostra que são quatro interseções, caracterizadas pela concentração de poder, personalismo, postura de espectador e evitar conflito. Abordaremos cada uma dessas características para contextualizar a cultura presente nas organizações brasileiras.

Existem duas expressões muito comuns na cultura brasileira e que demonstram bem o significado da característica concentração de poder: "manda quem pode, obedece quem tem juízo" e "você sabe com quem está falando?". Essas duas expressões refletem toda a carga autoritária nos relacionamentos, que conferem direitos especiais (reais e/ou imaginários) ao indivíduo em determinada posição de poder. O Brasil passou por diversas estruturas de poder diferentes, da monarquia à poliarquia, e movimentos políticos intensos que confirmam que

a sociedade brasileira tem se valido, de forma alternativa, da força militar tradicionalista e do poder racional-legal para o estabelecimento e a manutenção da autoridade, criando assim uma cultura de concentração de poder, baseada na hierarquia/subordinação. (Barros e Prates, 1996, p. 34)

Isso talvez possa justificar porque essa dimensão cultural está tão presente nas organizações brasileiras. Como bem observou Hofstede (1997) ao descrever o conceito de distância de poder, todas as sociedades apresentam níveis diferentes de desigualdade de poder e, de forma geral, demonstrando maior ou menor centralização da autoridade ou maior ou menor grau de 
liderança autocrática. No caso do Brasil, o resultado da pesquisa comandada por Hofstede confirma que os brasileiros valorizam a hierarquia e que a concentração de poder está presente na cultura brasileira.

Por outro lado, no Brasil, a rede de amigos ou parentes é o caminho mais natural para que as pessoas possam resolver seus problemas e, portanto, obter privilégios sobre os outros. O líder brasileiro, em geral, se diferencia pela posição hierárquica que ocupa e pelas relações pessoais que constrói, caracterizando assim seu alto grau de personalismo. Sabemos que o indivíduo isolado e sem relações que o favoreçam é considerado marginal em relação aos demais. Apenas para fins de comparação, vale tomar o exemplo da cultura norte-americana que, nesse sentido, é mais homogênea, igualitária e individualista. Já a cultura brasileira está mais para desigual, relacional e inclusiva (Tanure, 2009).

Ao retomarmos o estudo de Hofstede (1997), encontramos a dimensão individualismo X coletivismo, utilizada para explicar exatamente os comportamentos culturais que demonstram os laços e relações entre os membros de uma sociedade. A escala proposta por Hofstede traz em um dos extremos as sociedades com laços frágeis, em que o relacionamento entre os indivíduos é pautado pela troca objetiva, atendendo às suas necessidades próprias, como é o caso dos Estados Unidos, Austália, Canadá e Holanda. E, no outro extremo estão as sociedades que apresentam laços muito próximos, reforçando que os grupos formados acabam sendo considerados a extensão da família. Assim, todos olham pelos interesses do grupo e este se encarrega de fiscalizar e proteger o indivíduo quando for necessário. Nesse grupo encontram-se países da América Latina e alguns Asiáticos, como Indonésia, Paquistão, Tailândia e Cingapura, por exemplo. O Brasil está mais próximo das sociedades que valorizam o relacionamento com pessoas do grupo, ou seja, é considerado um pais coletivista, segundo Hofstede.

A característica postura de espectador acaba sendo uma consequência das duas anteriores. Acostumada às relações dependentes e submissas, a sociedade brasileira se orienta pela autoridade externa, quase que como um reflexo. Na maioria das vezes, a referência de poder é externa ao indivíduo, limitando a consciência e o senso crítico. Baixa iniciativa, pouca capacidade de realização por auto-determinação e transferência de responsabilidades das dificuldades para as lideranças são alguns dos comportamentos percebidos nas organizações em decorrência desse traço cultural. Tanure (2009) observa que isso faz com que o indivíduo 
se envolva em um clima de perplexidade e infantilização, em que, mesmo havendo liberdade de atuação, ele não sabe como agir ou não demonstra vontade própria e se sente forçado a conformar sua conduta segundo as expectativas da autoridade externa. Trata-se de um perfil que apresenta baixo desejo de mudança e uma aceitação passiva da realidade, como se incorporasse a figura do espectador.

Essa passividade e pouca iniciativa nos levam a outro traço cultural comum do brasileiro, que é a tendência a evitar conflitos. É uma característica muito mais de âmbito pessoal do que institucional, pois, segundo Tanure (2009), a sociedade brasileira valoriza a lealdade ao líder que, por sua vez, humaniza as relações buscando harmonia do grupo, alegria e descontração, levando a uma sedução afetiva para gerar comprometimento e coesão social. Como resultado, discordar, se opor ou discutir são atitudes pouco aceitáveis no grupo. Os conflitos não são tratados abertamente, os assuntos que geram incômodo tendem a ficar por debaixo da mesa pois, do contrário, podem comprometer o relacionamento, criar constrangimentos entre as pessoas ou minar a harmonia do grupo. A saída brasileira é usar soluções indiretas (triangulações) entre os pólos divergentes, mas que mantêm boas relações pessoais com ambos. No ambiente organizacional, é comum a transformação de embates abertos em alianças cooperativas, por meio de acordos prévios.

Voltando ao Modelo de Ação Cultural Brasileiro, proposto por Tanure (2009), percebe-se que no sistema de Lideres, a combinação dos traços de personalismo e concentração de poder tem como resultado o paternalismo ou patriarcalismo e patrimonialismo. É a percepção de que o patriarca tudo pode e aos membros do clã resta apenas pedir e obedecer; a rebeldia pode ter conseqüências, como a exclusão das relações do patriarca. A figura supridora e afetiva do pai, muito forte em função da valorização da família enquanto instituição-base da cultura brasileira, é confundida muitas vezes com o líder, gerando uma relação de dependência continuada dos liderados pelos líderes. Para que não ocorra uma ruptura, é preciso que o liderado se dedique e colabore em nome dos laços pessoais que foram construídos. É uma característica comum de sociedades onde o poder é distribuído de forma desigual, como é o caso do Brasil. Buscando relação com os estudos de Hofstede (1997), essa cultura paternalista está presente em sociedades que combinam alto índice de concentração de poder com baixo individualismo. 
Já no sistema Formal/Institucional, a combinação dos traços culturais concentração de poder e postura de espectador leva ao formalismo, uma característica muito própria dos brasileiros. No Brasil, o número de leis e regras, nem sempre respeitadas no dia-a-dia, gera um turbilhão de normatizações e burocracia com o intuito de se criar uma aparente estabilidade nas relações sociais. No entanto, surgem processos de ajustamento, reinterpretação das leis e escapadas exatamente para superar as especificidades das normas. Segundo Tanure (2009), como esses processos são permitidos e podem atingir configurações de nepotismo, favoritismo e até subornos, geram instabilidade e insegurança, levando consequentemente a mais normas e regras. A autora cita o exemplo da Constituição Brasileira, com 245 artigos no texto original (são 250 artigos e 80 emendas na versão revisada, aplicada atualmente ${ }^{5}$ ), que tem o intuito declarado de tentar garantir direitos ao povo, considerando vários aspectos muito específicos pela força da lei magna do país. Na prática, muitos desses direitos básicos sequer existem. A expressão "isso é para inglês ver" descreve bem essa distância entre norma e realidade.

Retomando o trabalho de Hofstede (1997), esse traço corresponderia à dimensão controle de incertezas, caracterizando a maneira como a sociedade se comporta em relação ao desconhecido. No Brasil, o índice de controle de incertezas é relativamente elevado demonstrando essa necessidade de gerar regras para tentar transmitir a sensação de segurança. O ambiente pode ser tomado por um clima mais tenso, envolvendo mais emoções e agressividade. Barros e Prates (1996) observam que o brasileiro busca por resultados de forma imediatista e possui baixa capacidade de provisionamento, o que leva a uma postura sem ansiedade para o futuro/incerteza.

No sistema dos Liderados, a flexibilidade é o resultado da articulação entre os traços postura de espectador e evitar conflito. Considerado pela autora um dos mais importantes traços no modelo de ação cultural, a flexibilidade é a versão do conhecido "jeitinho brasileiro" e suas principais características são a criatividade e a adaptabilidade. A criatividade é um adjetivo comum ao ambiente empresarial brasileiro e carrega consigo o elemento da inovação. As festas de carnaval e outras manifestações populares brasileiras são demonstrações originais da criatividade que permeia as relações no país. Já a adaptabilidade é uma capacidade criativa

\footnotetext{
${ }^{5}$ De acordo com o site na internet do Supremo Tribunal Federal, o texto, originalmente com 245 artigos, foi o resultado de 19 meses de trabalho dos deputados constituintes reunidos em Assembleia Nacional para analisar mais de 40 mil emendas e propostas. Atualmente a Constituição de 1988 tem 250 artigos e 80 emendas constitucionais, sendo seis delas de revisão.
} 
que se exercita dentro de determinados limites prefixados (Tanure, 2009). Isso ocorre exatamente dentro do ambiente organizacional, que possui normas e restrições. Em função delas, se ajustam processos para a criação de novos hábitos. Com essas características, as empresas demonstram uma habilidade grande de se ajustarem aos altos e baixos da economia, às alterações de governos e políticas. A adaptabilidade e criatividade também são valorizadas nos empregados, para que possam superar eventuais obstáculos nas organizações.

No sistema pessoal, a junção dos traços personalismo e evitar conflito leva à característica denominada lealdade pessoal. Tanure (2009) afirma que a coesão social no Brasil está sujeita a uma ética pessoal que se manifesta exatamente pela lealdade às pessoas. Isso significa que o membro de um grupo valoriza mais as necessidades do líder e dos outros membros do grupo do que as necessidades de um sistema maior, no qual ele está inserido. Esse traço é comum no ambiente empresarial brasileiro. Os liderados depositam toda sua confiança na pessoa do líder e ele passa a ser o elo que os conecta à organização. Como vimos, os relacionamentos pessoais são bastante valorizados e esse traço cultural representa o sentimento de pertencimento entre os envolvidos, que acaba por gerar um mecanismo de coesão: o chefe é o principal cliente.

Para finalizar, a impunidade é um traço cultural fortíssimo e tem reflexos tanto no sistema institucional/formal quanto no sistema pessoal. Trata-se de um dos elementos que pode reforçar ou minar a manutenção e estabilidade do modelo de Ação Cultural Brasileiro. De forma geral, o país tem a tendência de transformar em heróis aqueles que conseguem resultados positivos com a transgressão da lei (Barros e Prates, 1996). O oposto seria a meritocracia, ou premiação por mérito, muito utilizada nos Estados Unidos, principalmente onde existem prêmios respeitados em diversos setores. Sob a ótica cultural brasileira, recompensas por atitudes realizadoras são raras. Ao contrário, premia-se com impunidade quando se pratica algo moralmente incorreto, mas socialmente aceito. Lideres imunes à punição acabam fortalecendo sua posição de poder e conferindo consistência aos traços apresentados anteriormente.

Tanure (2009) propõe ainda uma evolução do modelo, ao eleger três principais pilares da cultura brasileira na interação com as organizações: o poder, as relações e a flexibilidade. De fato, essas são as características mais marcantes e que influenciam diretamente a gestão e o modo de administrar no Brasil. Em resumo, podemos afirmar que existe um estilo brasileiro, 
presente nas organizações, diferente do estilo de outros países com histórias, culturas e características muito diferentes. Esse estilo é marcado por traços fortes de hierarquia e grande capacidade de lidar com a incerteza, além do "jeitinho", que reúne flexibilidade, adaptabilidade e criatividade. 


\title{
CAPÍTUlO 3: O papel da Comunicação e das Relações Públicas Internacionais
}

\author{
Embora tenha trabalhado considerando a cultura uma variável por mais \\ de dez anos, continuo sendo surpreendido por quão pouco compreendo a \\ sua profunda influência em uma situação após a outra. (...) Fracassamos \\ ao não notar que a cultura, vista como formas de perceber, pensar e \\ reagir, consideradas válidas sem serem questionadas, era uma das \\ forças mais poderosas e estáveis que operam nas organizações. (Schein, \\ 2009, p. 230)
}

Por ser um elemento essencial na formação da estrutura das organizações, a cultura influencia diretamente a prática de comunicação e relações públicas nas empresas, impactando os relacionamentos entre pessoas, grupos, organizações e países. Autores como Schall (1983) e Freitas (1991) acreditam que o processo de comunicação nas empresas é responsável por ajudar a criar a cultura organizacional, considerando que as organizações são vistas como fenômeno de comunicação, sem o qual não existiriam. Já Hall (apud Bardhan e Weaver, 2011, p. 8) afirma que "cultura é comunicação e comunicação é cultura". Mirando o objetivo principal desse trabalho, neste capítulo, vamos apresentar conceitos e teorias que colaboram para reforçar essas afirmações.

\subsection{Cultura e Comunicação: as duas faces da mesma moeda}

Freitas (1991) argumenta que as culturas são criadas, sustentadas, transmitidas e mudadas através da interação social, que na empresa se expressa por meio de papéis informais na rede de comunicação. Essa rede formada pelos papéis informais faz a amarração das diversas partes da organização, transmitindo informações e interpretando os significados das informações para os outros envolvidos.

Cada vez mais, no ambiente empresarial, a comunicação vem se estabelecendo como um dos elementos estratégicos para entendimento das necessidades dos diversos públicos, incluindo funcionários e clientes, por exemplo. A comunicação vai além de uma simples ação ou de um fluxo de emissão e recepção.

Grunig (1992) comenta que existem duas teorias diferentes para explicar como a comunicação se comporta no âmbito das organizações. $\mathrm{O}$ autor chamou esses dois modelos de comunicação de paradigma simbólico e paradigma comportamental. O paradigma simbólico considera a comunicação como uma forma de defesa, em que a comunicação influencia os públicos a 
tomar as decisões que protegem a organização. Este modelo de comunicação está associado a conceitos como imagem, reputação, marca e identidade. Podemos citar como exemplo as campanhas publicitárias e as divulgações de posicionamentos para a imprensa. Este paradigma reduz a prática da comunicação a um papel tático nas organizações, de forma que os processos de comunicação mantenham o discurso e os interesses da organização em detrimento dos interesses dos seus públicos.

Por outro lado, o paradigma comportamental direciona esforços para que os profissionais e os processos de comunicação participem das decisões estratégicas da organização, propiciando a análise e o gerenciamento dos seus comportamentos. Atuando neste modelo a comunicação é vista como articuladora do relacionamento entre a organização e seus diversos públicos (Grunig, 1992), assumindo a condição de elemento estratégico. A prioridade aqui é estabelecer uma via de mão dupla que propicie o diálogo com os públicos estratégicos, incluindo-os nos processos de decisão da organização. De acordo com esse paradigma, as organizações que se dedicam a desempenhar processos de comunicação mais éticos são vistas mais positivamente pelos seus públicos de interesse

Abordagens teóricas como essa consideram a comunicação como um processo bilateral, interativo e participativo, em que todas as partes envolvidas podem tomar iniciativas. A ênfase é na comunicação como um processo, cujo significado é criado e trocado, e ao mesmo tempo, compartilhado entre as partes envolvidas. A comunicação, percebida como um processo de compartilhamento e troca de significados, vai além da dimensão interpessoal e se estende também ao sistema organizacional.

Nessa mesma linha, Sriramesh e Vercic (2009) consideram que a comunicação é uma ferramenta chave na construção de relacionamentos e que, portanto, é uma atividade estratégica por natureza. Ferrari (2011) também reforça esse ponto de vista, afirmando que

Por ser eminentemente proativa, a comunicação estratégica é um processo pelo qual a empresa conduz, intencionalmente, sua comunicação de modo que ela seja clara, aberta e com objetivos voltados pra o mercado e para seus públicos de interesse (Ferrari, 2011, p. 157)

A esse processo podemos chamar de relações públicas, uma atividade que gerencia a comunicação e os relacionamentos de forma específica nas organizações. Apenas para fins de identificação, adotaremos a seguinte definição de Grunig, Ferrari e França (2011) sobre o que 
seria o conceito contemporâneo de relações públicas: é uma função corporativa, pois ajuda a organização a definir suas políticas de comunicação e de relacionamento com seus públicos a fim de responder aos seus interesses estratégicos, o que lhe confere também uma função gerencial. Além disso, as relações públicas, enquanto prática de comunicação intercultural são profundamente impactadas pelos fluxos globais de poder, informação e capital (Bardhan e Weaver, 2011).

Praticar relações públicas nesse ambiente cultural pouco familiar, requer um entendimento sobre expectativas na condução das relações humanas. Nesse contexto, o olhar do profissional de comunicação e relações públicas sobre a cultura organizacional acrescenta conhecimentos a cerca de relacionamentos, influência, liderança, gestão de equipes, além de contribuir para endereçar melhor sentimentos muito comuns no ambiente de trabalho, tais como: manipulação, inveja, persuasão, carisma, verdade e autoconfiança.

É através da cultura e da comunicação que as pessoas dão sentido ao mundo em que vivem e atribuem significado às experiências organizacionais. Nessa linha, a comunicação atua no processo de compartilhamento de significados. Marchiori (2011) afirma que os estudos de comunicação organizacional fazem parte do contexto de análise das empresas e, por isso, acredita que a única forma de modificar uma organização é por meio de sua cultura. E, essa, por sua vez, está ligada ao processo de conhecimento e relacionamento que constrói significado para as pessoas, ou seja, a comunicação. São temas interligados, que atuam nas raízes da organização e posicionam a área e o profissional de comunicação de forma estratégica para atuar nesse ambiente.

Já para Moura e Ferrari (2015), a comunicação e a cultura são dimensões inseparáveis que atuam em sinergia. As autoras entendem que o profissional de relações públicas é um estrategista quando assume a gestão da comunicação corporativa em todas as suas dimensões, desde o fortalecimento dos elementos que compõem a identidade, passando pela gestão da marca, até a consolidação da boa reputação, o que pressupõe zelar pelos valores organizacionais da cultura, pela ética e pela diretrizes e políticas da organização.

Shiramesh e Vercic (2012) afirmam que enxergar a cultura e as relações públicas sobre o mesmo contexto significa reconhecer a atuação de forças conscientes e inconscientes sobre a organização. Isto é, seja de forma consciente ou não, todo ser humano é influenciado pela cultura e a cultura tem profundo impacto sobre o comportamento humano e isso inclui o jeito 
com que nos comunicamos, tanto profissionalmente quanto socialmente. Para Shiramesh e Vercic (2012), alguns fatores levaram acadêmicos e pesquisadores a focarem suas atenções no elo que existe entre cultura e relações públicas: a globalização, as mudanças no ensino e na prática de relações públicas e, por fim, a crescente influência e efetiva importância das relações públicas nas sociedades contemporâneas. A interdependência entre pessoas e organizações, movimento que tem crescido como conseqüência da globalização, torna os relacionamentos e interações comunicacionais ainda mais importantes.

Para os autores, há três formas de descrever a relação entre cultura e relações públicas: 1. A cultura como um ambiente que influencia a prática das relações públicas, que é a forma mais difundida; 2. Relações Públicas como uma cultura por si mesmo; 3. Relações Públicas impactando na cultura (tanto organizacional quanto social). Sendo que, para esses dois últimos, os estudos disponíveis são escassos. Eles utilizam a metáfora da ponte para descrever o papel das relações públicas nesse contexto: a comunicação é relevante para todos os tipos de organizações que estão expandindo para novos mercados e culturas; e as relações públicas serão chamadas para construir essa ponte, aproximando as diferenças culturais, sem desrespeitá-las. Além disso, chegam a preconizar que o futuro dependerá, necessariamente, da habilidade das pessoas de se comunicar e se relacionar bem com os outros.

Em uma abordagem mais instrumental, Ganesh (2015) entende que os meios de comunicação desempenham papel determinante na formação da cultura, pois eles definem os horizontes da nossa experiência e constroem um profundo senso comparativo do mundo à nossa volta assim, são uma parte constitutiva da nossa ecologia cultural. O autor registra diversos exemplos de como inovações tecnológicas para a evolução da comunicação transformaram a cultura e a forma de atuar coletivamente. É o caso do telégrafo, que fez com que a informação se deslocasse com maior velocidade do que as pessoas, pela primeira vez; ou da televisão e, mais recentemente, dos meios digitais, que levaram por exemplo à transformação das organizações de ação coletiva para grupos de ativistas com propósito e duração definidos.

Por outro lado, Ferrari (2015) defende que a análise da comunicação intercultural precisa ir além da simples comparação entre culturas, ou da identificação de semelhantes e diferentes. A ideia é se preocupar com o gerenciamento da comunicação intercultural, para que ocorra a adaptação do contexto cultural dos interlocutores, ou ainda, que se chegue a um consenso que 
satisfaça as partes. Além disso, a autora propõe a utilização dos modelos de gestão da comunicação de mão dupla com formas de diálogo, que facilitem a compreensão mútua, estimulem relações de confiança e contribuam para as trocas em diferentes dimensões, como a cultural, a política, a social e a comercial.

Em uma abordagem mais ousada, Grunig e Hunt (1984) e Sriramesh e White (1992) consideram que a cultura e a comunicação são sinônimas, uma vez que a cultura tem relação direta com os processos de comunicação, enfatizando, portanto que a identificação do ambiente cultural em que uma organização, entidade ou profissional está inserido é fundamental para o exercício da comunicação.

\subsection{Relações Públicas Internacionais para as organizações se adaptarem a ambientes culturais distintos}

Nesse sentido, também se destacam os estudos de Ferrari (2000, 2011, 2014). Em sua tese de doutorado, a pesquisadora apresentou uma ampla análise comparativa das características culturais e do cenário econômico, político e social da América Latina e sua influência nas práticas de comunicação em organizações brasileiras e chilenas.

Ferrari (2000) concluiu que o modelo de relações públicas praticado nas organizações sempre é resultado das trocas simbólicas e dos valores compartilhados que ocorrem nas organizações, incluindo daqueles decorrentes das culturas nacionais. Em uma de suas recentes publicações, Ferrari (2011) traz reflexões sobre a prática das Relações Públicas internacionais no cenário brasileiro e latino-americano, apresentando traços da cultura local e características latinoamericanas na gestão da comunicação. A autora representa uma contribuição efetiva para o presente estudo, principalmente porque contextualiza e relaciona os dois fatores que analisamos: a comunicação e a cultura.

Segundo a autora, a atuação do profissional de relações públicas nesse segmento é relativamente novo e teve início a partir das últimas décadas do século $\mathrm{XX}$, quando se intensificou o movimento de fusões, aquisições e instalações de multinacionais em diferentes continentes, forçando as empresas a conhecer novas realidades, lidar com hábitos e costumes até então inexplorados e, principalmente, a aprender como gerar resultados frente a traços culturais tão distintos. 
Nesse novo ambiente, as organizações tiveram de rapidamente adaptar valores, políticas, normas e diretrizes nos diferentes países nos quais se instalaram para assegurar um modelo de gestão que trouxesse os resultados esperados pela respectiva matriz, mas que também correspondesse às demandas dos cidadãos que vivem nas localidades hospedeiras. (Ferrari, 2011, p. 169)

Até então, iniciativas similares de desenvolver programas de relações públicas internacionais ou eram ignoradas, ou eram conduzidas com um viés mercadológico/comercial pela área de marketing, ou eram terceirizadas para uma agência de comunicação externa. O primeiro a introduzir os termos "internacional" e "global" nas ações de relações públicas foi Anderson (apud Ferrari, 2011), em 1989. Para o autor, as relações públicas internacionais tratavam de programas de comunicação específicos para cada mercado, com ações especialmente desenvolvidas e estruturadas para cada localidade. Já as relações públicas globais foram definidas como um programa global, que reconheceria as realidades dos públicos e se adaptaria de acordo com peculiaridades regionais, levando em consideração o alcance geográfico e a flexibilidade na tomada de decisão.

Outros autores (Black, 1994; Wilcox, Cameron e Xifra, 2008; Wakefield, 2001) também trataram de descrever e abordar as funções das relações públicas internacionais. Nesse cenário destaca-se duas obras relevantes: International Public Relations: a comparative analysis, de Culbertson e Chen (1996), que foi a primeira publicação que tratou sobre relações públicas internacionais; e The Global Public Relations Handbook, de Sriramesh e Vercic (2003 e 2009), que é considerada a mais importante obra de referência sobre o tema.

Ferrari (2011) traz ainda uma abordagem mais ampla para a questão do contexto cultural nas organizações, ao questionar de que maneira as empresas devem adequar suas estratégias de comunicação para conseguirem adaptar-se aos ambientes culturais distintos. Problemas enfrentados pelas organizações, como preconceitos, estereótipos e choque cultural, podem ser tratados com a utilização de princípios de relações públicas internacionais para ajudar as empresas a entender e a atuar em um contexto multicultural.

Porém, essa parece ser uma das raras publicações locais sobre o tema. Ainda faltam registros eficientes e referenciais teóricos expressivos, sobretudo na área de Comunicação e Relações Públicas, que considerem o tema da influência da cultura (nacional ou organizacional) sobre a estrutura das empresas e dos departamentos de comunicação, principalmente em países fora 
do eixo EUA-Europa. Por outro lado, no contexto da globalização e à medida que as mudanças culturais se tornam constantes no ambiente das organizações, a comunicação vem merecendo maior atenção por parte dos executivos e gestores de empresas. Torna-se cada vez mais difícil gerar resultados, se for mantido o velho modelo de gestão autoritária, paternalista, que evidencia a inexistência do dialogo ou mesmo a distância entre discurso e prática. $\mathrm{O}$ cenário empresarial e global exigem uma postura que privilegie a comunicação, respeitando as diferenças culturais.

Mas não se trata de qualquer comunicação, ou a comunicação a qualquer preço. Na sequência, vamos abordar as teorias que refletem a prática excelente de comunicação e relações públicas, que serão essenciais para a construção do referencial teórico que embasará a análise da pesquisa.

\subsection{Os quatro modelos de Relações Públicas}

A primeira abordagem teórica é a tipologia dos modelos de prática de relações públicas, desenvolvido por Grunig e Hunt (1984), um dos principais estudos para compreender a prática das relações públicas no contexto organizacional. Esse modelo nos dá bases para analisar por que as organizações se comunicam de determinada maneira, em diferentes situações (Ferrari, 2011). Trata-se de uma tipologia universal, que define Relações Públicas como a gestão da comunicação entre uma organização e seus públicos.

Segundo os autores, os quatro modelos descrevem de maneira simplificada a prática das relações públicas ao longo da história, mas também apresentam indicações de como exercer a atividade de comunicação nas dimensões técnica, gerencial e estratégica. O Quadro 7 descreve brevemente cada um dos quatro modelos dessa teoria.

\section{Quadro 7: Os quatro modelos de práticas de relações públicas}

\begin{tabular}{|c|c|c|}
\hline MODELO & DESCRIÇÃO & EXEMPLO \\
\hline $\begin{array}{l}\text { Agência de } \\
\text { imprensa }\end{array}$ & $\begin{array}{l}\text { Nesse modelo, as atividades de } \\
\text { relações públicas têm o único } \\
\text { propósito de obter publicidade } \\
\text { favorável para uma organização ou } \\
\text { para indivíduos na mídia de massa. O }\end{array}$ & $\begin{array}{l}\text { Tem raízes no século 19, } \\
\text { quando profissionais } \\
\text { trabalhavam para influenciar a } \\
\text { opinião pública, criando } \\
\text { notícias e divulgando "meias- }\end{array}$ \\
\hline
\end{tabular}




\begin{tabular}{|c|c|c|}
\hline & $\begin{array}{l}\text { fluxo da comunicação é de mão única, } \\
\text { o que promove produtos e serviços a } \\
\text { partir de informação exagerada e nem } \\
\text { sempre correta. Não há investimento } \\
\text { em pesquisas ou preocupação ética. O } \\
\text { único objetivo é manipular } \\
\text { comportamentos. }\end{array}$ & $\begin{array}{l}\text { verdades". O que importa é } \\
\text { estar nas manchetes! } \\
\text { Atualmente, a prática desse } \\
\text { modelo pode ser percebida na } \\
\text { indústria do entretenimento e } \\
\text { celebridades. }\end{array}$ \\
\hline $\begin{array}{l}2 . \\
\text { Informação } \\
\text { Pública }\end{array}$ & $\begin{array}{l}\text { Também de mão única, esse modelo } \\
\text { entende que as atividades de relações } \\
\text { públicas servem para disseminar } \\
\text { informações pela mídia de massa, } \\
\text { utilizando jornalistas internamente (“in } \\
\text { house”), de forma objetiva. Ainda não } \\
\text { utiliza pesquisa para guiar o trabalho, } \\
\text { mas prioriza a divulgação melhor } \\
\text { apurada. }\end{array}$ & $\begin{array}{l}\text { No início do século } 20 \text {, se } \\
\text { fazia um pouco mais do que } \\
\text { apenas distribuir informação. } \\
\text { Press-releases, folhetos e } \\
\text { conteúdo online não interativo } \\
\text { são algumas ferramentas para } \\
\text { divulgar informações. }\end{array}$ \\
\hline $\begin{array}{l}3 . \\
\text { Assimétrico } \\
\text { de duas } \\
\text { mãos }\end{array}$ & $\begin{array}{l}\text { Mais eficaz que os dois anteriores, } \\
\text { utiliza a pesquisa para identificar as } \\
\text { expectativas e opiniões dos públicos. } \\
\text { O objetivo das ações é persuadir e } \\
\text { levar o público a se comportar como a } \\
\text { organização espera. Qualquer } \\
\text { alteração necessária para resolver um } \\
\text { conflito deve vir do público, pois a } \\
\text { organização está sempre correta e não } \\
\text { se preocupa em alterar seu } \\
\text { comportamento. }\end{array}$ & $\begin{array}{l}\text { O mundo do consumo pós } \\
\text { segunda guerra mundial } \\
\text { trouxe a necessidade de uma } \\
\text { comunicação } \\
\text { direcionada e altamente } \\
\text { persuasiva. A divulgação feita } \\
\text { pela indústria da moda é um } \\
\text { exemplo. }\end{array}$ \\
\hline $\begin{array}{l}4 . \\
\text { Simétrico } \\
\text { de duas } \\
\text { mãos }\end{array}$ & $\begin{array}{l}\text { Prática baseada em pesquisas, } \\
\text { utilizando a comunicação para } \\
\text { administrar conflitos, negociar e } \\
\text { aperfeiçoar o entendimento mútuo }\end{array}$ & $\begin{array}{l}\text { Hoje pode ser visto como um } \\
\text { modelo utópico, uma vez que } \\
\text { o profissional de RP } \\
\text { representa o interesse de todas }\end{array}$ \\
\hline
\end{tabular}




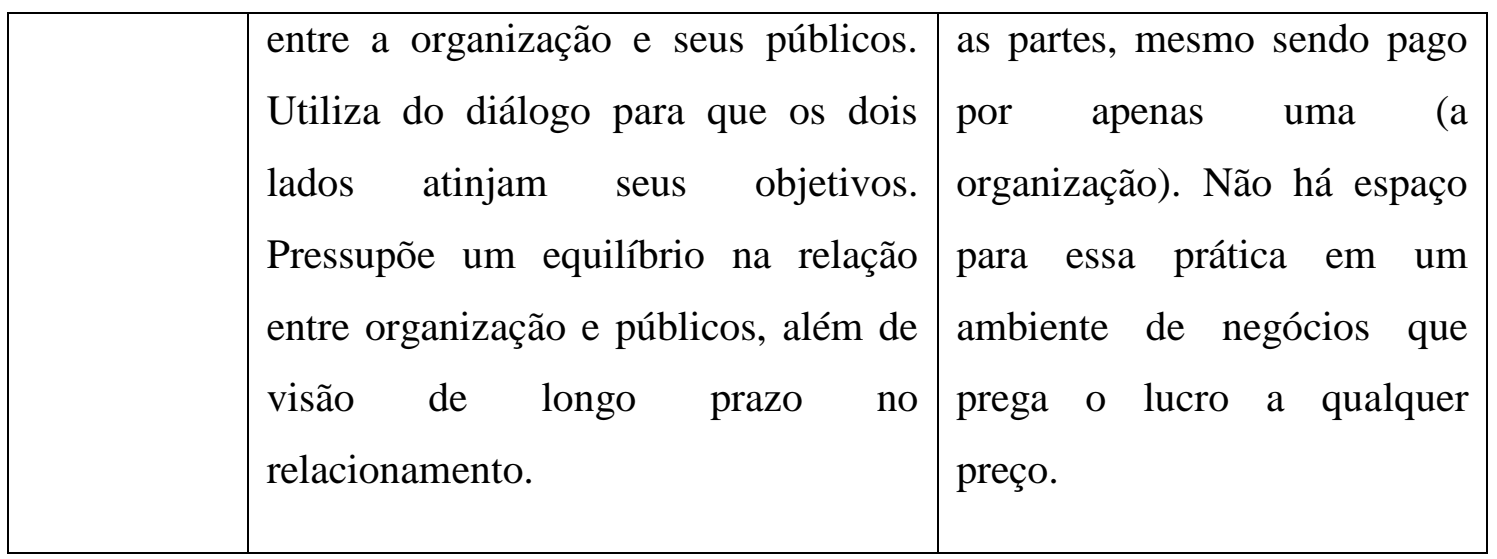

Fonte: a autora, com base em Grunig e Hunt (1984) e Ferrari (2011, p. 225).

É importante destacar que esses modelos podem coexistir em uma mesma organização, dependendo de sua realidade. Uma empresa pode, perfeitamente, adotar características do modelo 1, em determinado contexto e, em outra situação, utilizar o modelo 4. Em seus resultados de pesquisa, Ferrari (2000) conclui que o modelo de relações públicas praticado nas organizações sempre é resultado do contexto cultural, da vulnerabilidade do ambiente, dos modelos de gestão praticado pela organização e dos valores compartilhados que ocorrem no interior da organização, assim como das demandas externas que pressionam ou oferecem oportunidades.

Como bem registrou Ferrari (2011), o modelo de relações públicas praticado define o papel e as funções a serem desempenhadas pelos profissionais de comunicação. Portanto, a tipologia dos modelos de prática de relações públicas continua sendo um parâmetro muito utilizado por pesquisadores para medir o processo da atividade nas organizações. Além disso, esses modelos têm sido frequentemente utilizados por pesquisadores como eixos de matriz de análise para verificar o comportamento das organizações em diferentes situações. É exatamente o que faremos para analisar os resultados da presente pesquisa (ver Metodologia capítulo

\subsection{A Teoria da Excelência em Relações Públicas}

A segunda abordagem é a Teoria da Excelência (1992), resultado de um extenso estudo coordenado por James E. Grunig, que teve início em 1985, com um grupo de seis pesquisadores - Larissa Grunig, David Dozier, William Ehling, Jon White, Fred Repper, além do próprio James Grunig, patrocinados pela Internacional Association of Business 
Communicators Reserch Foundation (Fundação de Pesquisa da Associação Internacional de Comunicadores Empresariais).

Para realizar esse estudo, foram pesquisadas 327 organizações nos Estados Unidos, Canadá e Reino Unido, com o objetivo de identificar como empresas, agências governamentais, organizações sem fins lucrativos e associações comerciais e de profissionais praticavam as relações públicas de forma excelente. Como resultado, produziu-se uma teoria ampla e geral de relações públicas que acabou por integrar outras teorias disponíveis na época e culminar na publicação de três livros de grande relevância para os profissionais da área (Grunig, 2011). Ao oferecer uma estrutura conceitual para a prática profissional de relações públicas, a Teoria da Excelência é aplicável a diferentes cenários organizacionais e é reconhecida como um componente fundamental para a gestão eficaz em todo mundo.

Um dos principais resultados do Estudo da Excelência, nome dado pelo próprio Grunig (2011), foi a apresentação de dez princípios genéricos, que descrevem as características de departamentos e programas de relações públicas e o contexto interno e externo da organização. Os princípios estão dispostos em sete categorias que representam as principais áreas de estudo e prática da atividade, conforme demonstrado no Quadro 8.

\section{Quadro 8: Categorias e princípios genéricos de relações públicas de excelência}

\begin{tabular}{|c|c|c|}
\hline CATEGORIA & PRINCIPIO & DETALHES \\
\hline \multirow{2}{*}{$\begin{array}{c}\text { Empoderamento } \\
\text { da função de } \\
\text { Relações } \\
\text { Públicas }\end{array}$} & $\begin{array}{l}\text { 1. Envolvimento do executivo de } \\
\text { relações públicas na administração } \\
\text { estratégica }\end{array}$ & $\begin{array}{l}\text { O alto executivo de RP } \\
\text { participa dos processos de } \\
\text { gestão estratégica e tomada } \\
\text { de decisões. Além disso, os } \\
\text { programas de comunicação } \\
\text { são desenvolvidos para } \\
\text { públicos estratégicos. }\end{array}$ \\
\hline & $\begin{array}{l}\text { 2. Participação direta do executivo } \\
\text { de relações públicas com a alta } \\
\text { administração/CEO }\end{array}$ & $\begin{array}{l}\text { O alto executivo de RP é } \\
\text { membro da coalizão } \\
\text { dominante da organização } \\
\text { ou se reporta diretamente } \\
\text { aos diretores executivos que }\end{array}$ \\
\hline
\end{tabular}




\begin{tabular}{|c|c|c|}
\hline & & pertencem a ela. \\
\hline & $\begin{array}{l}\text { 3. Diversidade em todos os papéis } \\
\text { desempenhados pelos profissionais } \\
\text { no departamento de relações } \\
\text { públicas }\end{array}$ & $\begin{array}{l}\text { Diversidade de gênero, raça, } \\
\text { etnia e cultura incorporadas } \\
\text { em todos os papéis } \\
\text { desempenhados } \\
\text { relações públicas. }\end{array}$ \\
\hline \multirow{2}{*}{$\begin{array}{l}\text { Os papéis em } \\
\text { Relações } \\
\text { Públicas }\end{array}$} & $\begin{array}{l}\text { 4. Departamento de relações } \\
\text { públicas coordenado por um gestor } \\
\text { e não por um técnico }\end{array}$ & $\begin{array}{l}\text { Ter ao menos um gerente de } \\
\text { comunicação, que elabora e } \\
\text { coordena os programas de } \\
\text { RP. }\end{array}$ \\
\hline & $\begin{array}{l}\text { 5. Profundo conhecimento do papel } \\
\text { de gestor de relações públicas, por } \\
\text { meio da educação continuada e da } \\
\text { participação em eventos científicos }\end{array}$ & $\begin{array}{l}\text { O alto executivo de RP ou } \\
\text { outros no departamento } \\
\text { devem ter conhecimento } \\
\text { necessário para o papel } \\
\text { gerencial. }\end{array}$ \\
\hline \multirow{2}{*}{$\begin{array}{l}\text { Organização da } \\
\text { função de } \\
\text { comunicação, } \\
\text { relacionamento } \\
\text { com outras } \\
\text { funções e } \\
\text { utilização de } \\
\text { consultorias }\end{array}$} & $\begin{array}{l}\text { 6. Função integrada de relações } \\
\text { públicas, mediante o gerenciamento } \\
\text { da comunicação interna e externa } \\
\text { juntas, no mesmo departamento }\end{array}$ & $\begin{array}{l}\text { Somente em um sistema de } \\
\text { RP integradas é possível } \\
\text { desenvolver programas de } \\
\text { comunicação para públicos } \\
\text { estratégicos. }\end{array}$ \\
\hline & $\begin{array}{l}\text { 7. Relações públicas como função } \\
\text { gerencial, separada de outros } \\
\text { departamentos (ex. Marketing, RH) }\end{array}$ & $\begin{array}{l}\text { Trabalhando em conjunto, } \\
\text { como pares de seus colegas } \\
\text { de outros departamentos, } \\
\text { com poucos conflitos e } \\
\text { pouca competição com } \\
\text { outras funções gerenciais. }\end{array}$ \\
\hline $\begin{array}{l}\text { Modelos de } \\
\text { Relações } \\
\text { Públicas }\end{array}$ & $\begin{array}{l}\text { 8. Uso do modelo simétrico de } \\
\text { relações públicas, por meio da } \\
\text { compreensão mútua de interesses } \\
\text { entre organização e públicos e vice- }\end{array}$ & $\begin{array}{l}\text { Relações Públicas excelentes } \\
\text { são baseadas em pesquisas, } \\
\text { são simétricas, com planos } \\
\text { de comunicação que }\end{array}$ \\
\hline
\end{tabular}




\begin{tabular}{|c|c|c|}
\hline & versa & atendam às necessidades de \\
\hline & $\begin{array}{l}\text { 9. Uso do sistema simétrico de } \\
\text { comunicação interna, dando ênfase } \\
\text { à pesquisa como instrumento de } \\
\text { identificação de expectativas }\end{array}$ & \\
\hline $\begin{array}{c}\text { Contexto } \\
\text { organizacional } \\
\text { de RP } \\
\text { excelentes }\end{array}$ & $\begin{array}{l}\text { 10.Contexto organizacional } \\
\text { participativo para a prática da } \\
\text { excelência da comunicação }\end{array}$ & $\begin{array}{l}\text { Até que ponto as } \\
\text { características de estrutura, } \\
\text { cultura e poder da coalizão } \\
\text { dominante pressupõem a } \\
\text { prática de RP excelentes. }\end{array}$ \\
\hline
\end{tabular}

Fonte: a autora, com base em Grunig (2011, p.53-68) e Ferrari (2011, p.164 ).

Ferrari (2011) afirma que, por ter sido aplicada em diferentes países e contextos diversos, a teoria e os princípios se aplicam globalmente desde que sejam observadas as diferenças culturais de cada país. Assim, a autora acredita que é possível implantar uma visão intercultural para a prática das relações públicas internacionais estabelecendo parâmetros para a elaboração de planejamento estratégico de comunicação a nível global. Assim, da mesma forma que foram tratados os quatro modelos de práticas de relações públicas, alguns dos 10 princípios de excelência serão utilizados para analisar os resultados da pesquisa a partir de uma matriz. Os detalhes sobre essa utilização estão descritos no capítulo a seguir, sobre metodologia. 


\section{CAPÍTULO 4: Metodologia: descrição da pesquisa realizada}

Este estudo utilizou a pesquisa descritiva, que, segundo Hair et al. (2005), tem o propósito de observar, registrar, analisar e correlacionar fatos. Por meio desse tipo de pesquisa, procura-se saber, com a melhor precisão possível, qual a frequência do fenômeno e suas possíveis relações com outros. Já para Selltiz et al. (1975), um estudo descritivo tem a função, entre outras, de aumentar o conhecimento do pesquisador sobre o fenômeno que deseja investigar e de esclarecer conceitos. Este tipo de estudo analisa um fenômeno ou situação num dado ponto do tempo que, sintetizado estatisticamente, fornece dados transversais e descreve as características da população estudada (HAIR et al., 2005). Esta pesquisa não pretende estabelecer relações de causalidade, e sim relações entre as variáveis - cultura e comunicação. Segundo Knight e Kim (2009) é indicado realizar uma pesquisa descritiva, se preocupando em relacionar as variáveis envolvidas no problema.

Em outras palavras, esta pesquisa pretende investigar as características e traços culturais de organizações brasileiras e relacioná-las com a prática de comunicação e RP nas empresas. O tipo de análise a ser utilizado é o quantitativo, com os dados coletados sendo analisados por meio de testes estatísticos. A análise quantitativa é frequentemente aplicada em estudos descritivos que procuram descobrir e classificar a relação entre variáveis. (Richardson, 2008).

Ferrari e Moura (2015), consideram a pesquisa como uma etapa fundamental para a atividade de relações públicas, pois sistematiza informações para descrever e compreender situações e comprovar hipóteses sobre o comportamento dos públicos, suas expectativas e as consequências que podem causar ao processo de comunicação. Da mesma forma, as autoras valorizam a interdisciplinaridade, argumentando que as relações públicas utilizam o saber de outras disciplinas das ciências sociais para exercer sua função de administrar os relacionamentos dos públicos com as organizações e vice-versa.

Alguns autores como Ibarra (2008), Ogliastri (1999) e Ferrari (2001, 2011) afirmam que existem traços culturais e comportamentais comuns que determinam e influenciam a prática de comunicação nas empresas. Nosso objetivo é verificar a afirmação dos autores a partir de uma questão norteadora, que esta pesquisa pretende responder: A cultura organizacional tem influência sobre as atividades e processos de comunicação nas empresas brasileiras? 
Assim, a elaboração deste estudo está dividida duas etapas: a pesquisa secundária, que foi realizada por meio da recopilação da literatura especializada e, num segundo momento, a pesquisa de campo. A primeira etapa envolveu a revisão da literatura especializada com a finalidade de construir um arcabouço teórico sobre os temas do estudo em questão, assim como trazer ao corpo do trabalho os conceitos que serão chave para o referido tema. Como vimos na sessão anterior, o referencial teórico incluiu assuntos como o cenário contemporâneo da sociedade e a influência do fenômeno da globalização, teorias, aspectos e tipologia de cultura nacional e de cultura organizacional, além de teorias e modelos de prática de relações públicas que marcam a comunicação das organizações.

A partir do levantamento bibliográfico de teses, dissertações e pesquisas detectou-se a existência de pouca literatura que relacione a cultura nacional, a cultura organizacional e os processos de comunicação nas empresas, principalmente no contexto das organizações brasileiras.

Para dimensionar a carência de estudos e pesquisas no Brasil sobre o tema, foram encontrados em consulta realizada no Portal de Periódicos da Capes ${ }^{6} 390$ registros de artigos, textos ou publicações sobre o tema, a partir do ano de 2001, sendo que 113 documentos com buscas de palavras em português (cultura, comunicação) e 340 com as mesas palavras na língua espanhola. Quando a busca das palavras foi no idioma inglês (culture, communication), esse número atingiu 22.480 registros no mesmo período. Isso demonstra que ainda no Brasil a pesquisa encontra-se em estágio elementar, quando comparada com a realidade dos países desenvolvidos e de idioma inglês, principalmente.

Essa pesquisa mostrou que nos últimos 15 anos foram produzidas 30 publicações por ano sobre o tema na língua local (português), enquanto que existem mais de 1.700 publicações em língua estrangeira (espanhol e inglês), no mesmo período, em todo o mundo. Os resultados obtidos a partir desse levantamento nos levam às seguintes conclusões: a) as pesquisas sobre cultura e comunicação em organizações brasileiras são escassas, considerando a importância do tema; ou b) a questão da cultura e da comunicação talvez sejam objeto de análise por

\footnotetext{
${ }^{6}$ O Portal de Periódicos da Capes (Coordenação de Aperfeiçoamento de Pessoal de Nível Superior), mantido pelo governo brasileiro, é uma biblioteca virtual que reúne e disponibiliza ao meio acadêmico o melhor da produção científica internacional. Ele conta com um acervo de mais de 37 mil títulos com texto completo, 130 bases referenciais, 12 bases dedicadas exclusivamente a patentes, além de livros, enciclopédias e obras de referência, normas técnicas, estatísticas e conteúdo audiovisual, cobrindo todas as áreas do conhecimento.
} 
países de outros continentes e não um assunto recorrente localmente. Sem entrar no mérito se as conclusões são ou não verdadeiras, fica claro que existe pouco interesse em trabalhos e pesquisas de campo para conhecer e identificar questões sobre a cultura e a comunicação no Brasil.

Sendo assim, com objetivo de verificar os processos das organizações e as melhores práticas de comunicação partimos para a segunda etapa do estudo, que envolveu uma pesquisa de campo, com a aplicação de questionário online, tipo survey, com 50 empresas brasileiras.

\subsection{Características e critérios de seleção da amostra}

A amostra foi constituída por organizações de capital nacional e de atuação local - e não global, ou multinacional. para que os aspectos culturais locais pudessem ser diretamente identificados. Procuramos evitar incluir organizações com perfil internacional, para não ocorrer contaminação da amostra. Essa amostra foi delimitada por uma razão especificamente: o acesso às empresas, o que representa um entrave para execução de pesquisas acadêmicas no Brasil. Por isso, a opção foi por não restringir organizações por tipo, setor ou porte, com algum critério específico.

A partir do ranking Guia Exame - Maiores \& Melhores (2015), 500 maiores empresas do Brasil e de listas de empresas disponíveis em associações setoriais (como a Abrapcorp, por exemplo), foram contatadas empresas buscando o maior número possível de respostas para que o resultado pudesse ser satisfatório. A pesquisa foi enviada a, pelo menos 150 empresas e a amostra constituiu-se como não probabilística, por conveniência, obtendo uma amostra válida de 50 respostas, correspondendo a $33 \%$ da amostra ideal.

\subsection{Instrumentos de pesquisa}

O questionário foi escolhido como instrumento de coleta de dados por ser comumente utilizado em surveys. (Hair et al., 2005). Survey é um procedimento para coleta de dados primários, utilizado quando a pesquisa envolve um grande número de indivíduos. Os dados coletados podem variar entre crenças, opiniões, atitudes e informações gerais sobre a experiência do indivíduo (Hair et al., 2005, p. 157). Uma das principais características da survey é o interesse em produzir descrições quantitativas de uma população e fazer uso de um instrumento predefinido (Richardson, 2008). 
O questionário (ver Anexo A) conta com questões 17 questões que se desdobram em perguntas fechadas e abertas. Ele foi aplicado no período de junho a outubro de 2015, por meio de coleta digital, utilizando o software aberto "Survey Monkey". Segundo Toni (2014), a pesquisa on-line já é o modo mais importante de coleta de dados globalmente, ultrapassando os modos tradicionais de coleta pessoal e telefônica. De acordo com o autor, existe uma regra prática que diz que: se a penetração de internet no país a ser pesquisado for maior do que $40 \%$, a adoção de pesquisas on-line é válida. A Pesquisa Nacional por Amostragem Domiciliar (Pnad) do Instituto Brasileiro de Geografia e Estatística (IBGE), realizada em 2011 (mais recente), registrou que 46,5\% dos brasileiros possuem acesso à internet, o que credencia a utilização desse modo de coleta para pesquisas.

Em junho de 2014 foi realizado um pré-teste com representantes de três empresas que atuam no Brasil, com o objetivo de verificar a adequação do questionário e do formato de coleta de dados. Os resultados obtidos foram satisfatórios, as respostas foram validadas e não houve ocorrência que mereça registro. Os respondentes preencheram o questionário durante o prazo esperado (máximo de 20 minutos) e alguns apontaram sugestões de melhoria nos enunciados que foram contempladas para a realização da coleta de dados, posteriormente. É importante destacar que as pessoas que responderam ao pré-teste não foram convidadas a participar da pesquisa propriamente dita.

O questionário constava de em três partes. A primeira parte tomou como base o instrumento de avaliação da cultura organizacional, proposto por Cameron e Quinn (2006), a partir do modelo de valores competitivos, que tem por objetivo diagnosticar a presença dos tipos culturais a saber: clã, inovativa, de mercado ou hierárquico. Este modelo de questionário foi utilizado por mais de mil organizações e tem sido aplicado para diagnosticar importantes aspectos culturais e identificar a cultura atual de uma organização.

O questionário é chamado de OCAI (Organizational Culture Assessment Instrument), para avaliar seis principais dimensões da cultura organizacional: características dominantes, liderança organizacional, gerenciamento de pessoas e equipes, união organizacional, ênfase estratégica e critérios de sucesso. Para cada uma dessas dimensões é apresentado um conjunto de quatro frases, representando os quatro tipos de cultura. $\mathrm{O}$ instrumento original previa que o respondente distribuísse 100 pontos entre as quatro alternativas, de acordo com a proximidade da realidade da organização que ele representa, e ainda, havia uma coluna para ranquear 
também o que seriam aspectos desejados pelo respondente, identificando demandas futuras e oportunidades de melhoria. Foi feita uma adaptação para retirar essa coluna, já que era um tema que não interessava diretamente a essa pesquisa.

Além disso, com o objetivo de facilitar as respostas e deixar o instrumento ainda mais objetivo, foi feita uma adaptação e utilizada a escala de Likert (de 1 a 5), em que o respondente deveria indicar de que forma cada uma das características se aproximava da sua organização, variando de 1: discordo totalmente a 5: concordo totalmente. Versão similar a essa foi testada e aplicada em outras pesquisas, conforme registrou Barreto, Kishore e Reis (2012).

A segunda parte do questionário contou com questões fechadas e abertas, abordando aspectos relacionados ao processo de comunicação nas organizações, tais como: composição e estruturação da área, construção de relacionamentos, terceirização, funções e responsabilidades. Ferrari e Moura (2015) destacam o papel estratégico do comunicador tem se ampliado principalmente na construção e preservação do valor da marca e no estabelecimento dos relacionamentos de longo prazo com os públicos estratégicos. Segundo as autoras, esse papel só poderá ser exercido quando o profissional utiliza a pesquisa como um instrumento que traga respostas às suas inquietações.

Dessa forma, como base para as questões, utilizou-se dois estudos globais, que foram aplicados em diferentes países do mundo e que têm sido essenciais para entender a prática das relações públicas no contexto organizacional e da sociedade: a tipologia dos modelos de prática de relações públicas, desenvolvido por Grunig e Hunt (1984); a teoria da excelênc, preconizada por James Grunig (1992).

$\mathrm{Na}$ terceira e última parte do questionário foram utilizadas questões de caráter demográfico, tais como gênero, idade, grau de formação, entre outras, com o objetivo de conhecer melhor o perfil da amostra. De alguma forma, essas questões também contribuíram com os resultados da pesquisa, pois por meio do conteúdo gerado a partir desse perfil foi possível realizar o cruzamento dos dados com traços e características das empresas, por exemplo.

Diversas teses de doutorado e dissertações de mestrado costumam utilizar essas teorias, demonstrando que essas tipologias são replicáveis em outros estudos, o que confere à pesquisa o rigor teórico-metodológico necessário para conhecer melhor as práticas e 
realidades organizacionais. Dessa forma, acredita-se que os objetivos norteadores do estudo foram contemplados e fundamentam o questionário, enquanto principal instrumento da pesquisa.

Além do questionário, a análise do roteiro de pesquisa (ver Anexo B) contribuiu para que os objetivos do trabalho fossem contemplados desde o princípio da elaboração da pesquisa. Ele foi construído de forma que as respostas dos entrevistados fossem vinculadas a indicadores e categorias previamente estabelecidos.

$\mathrm{Na}$ análise do roteiro de pesquisa, as respostas para as questões de cultura foram segmentadas de acordo com os quatro tipos de cultura organizacional de Cameron e Quinn (2006). No caso das questões de comunicação, as respostas corresponderiam aos modelos de Relações Públicas de Grunig e Hunt (1984) ou a prática de Relações Públicas excelentes (Grunig et. AL 1992). Nesse sentido, quando ocorresse uma resposta que preencheria esses quesitos, o respondente receberia um ponto. Para a definição da pontuação, foi estabelecida a regra de enumeração: em um conjunto de respostas, verifica-se a presença ou a ausência de elementos e calcula-se a freqüência desses elementos. Quanto maior a freqüência de aparição, maior será a importância de uma unidade de registro.

\section{3 Procedimentos preparatórios e análise dos resultados obtidos}

Com as respostas dos questionários em mãos, deu-se início à preparação e codificação dos dados, já entre os primeiros procedimentos estatísticos necessários para a análise do resultado. A cada um dos respondentes foi atribuído um número que passou a os identificar, uma vez que lhes foi garantido o anonimato nas respostas e na divulgação dos resultados. As 23 questões sobre cultura também foram numeradas e codificadas, assim como as 12 questões sobre comunicação e as 13 questões que apresentavam dados demográficos sobre os respondentes.

Na sequência, cada uma das respostas dos 50 respondentes foi transformada em números, para que o resultado pudesse ser analisado de forma isenta e padronizada pelo estatístico. Apenas a título de exemplo, às respostas das questões sobre cultura foram atribuídos números de $1 \mathrm{a} 5$, dependendo do que o respondente elegeu: 1 se a resposta marcada foi discordo totalmente, 2 para discordo ou 5 se a resposta foi concordo totalmente. Da mesma forma, nas questões 
sobre comunicação, em que o respondente poderia escolher a resposta entre "verdadeiro" ou "falso", ou "sim" e "não" foi atribuído um número que identificasse cada resposta: 1 ou 2. Caso a questão não tenha sido respondida ou anulada pelo respondente o número que a identificou foi o zero. E assim por diante, até se obter uma tabela completa com números identificando os respondentes e números atribuídos a cada resposta.

A partir da base de dados preparada foi possível iniciar a análise estatística. Os dados foram tabulados, mensurados e analisados de forma descritiva, por um profissional estatístico especializado, com o auxílio do software R. Para identificar em que tipo de cultura cada empresa pesquisada se encontrava, realizou-se a somatória e, na sequência, para verificar qual seria o tipo predominante, interpretou-se a proporção de cada categoria/tipo de cultura das respostas, conforme análise do roteiro de pesquisa previamente elaborado. $\mathrm{Na}$ Tabela 1, localizada no Anexo C, tem-se para cada empresa (ID) a proporção de cada tipo cultural (inovativa, clã, hierárquica e de mercado).

É importante notar que cada empresa contém quatro informações (proporções) representando os tipos de cultura organizacionais encontrados na empresa, segundo a tipologia de Cameron e Quinn (2006). Para que a análise dos dados fosse realizada de forma a representar a realidade, as empresas com características semelhantes foram agrupadas, utilizando-se a técnica de análise de agrupamento ou cluster. O objetivo dessa análise foi reunir as empresas em diferentes grupos, de forma que cada grupo obtivesse "proporções" semelhantes segundo uma distância.

A análise de cluster é uma técnica estatística, que emprega métodos aglomerativos hierárquicos, caracterizados por determinado critério para definir a distância entre os grupos. É uma das técnicas mais utilizadas para descoberta de agrupamentos e identificação de importantes distribuições e padrões que permitem compreender e interpretar os dados obtidos (Haldiki, 2001). Por meio da análise de cluster é possível segmentar dados heterogêneos em subgrupos homogêneos, de forma que os elementos se agrupem de acordo com comportamento semelhante, tornando essa análise diferente da classificação pura e simples.

A maioria dos métodos de análise de cluster requer uma medida de similaridade entre os elementos a serem agrupados. Essa medida, em geral, é expressa como uma função distância ou métrica. No caso específico do presente estudo foi considerado a distância euclidiana. A 
distância euclidiana é a distância geométrica no espaço multidimensional e é normalmente apresentada na forma de uma matriz, ou seja, uma matriz de similaridade (Haldiki, 2001).

Os grupos, nos métodos aglomerativos hierárquicos, são geralmente apresentados por diagramas bi-dimensionais ou diagrama e árvore, chamados de dendograma. Neste diagrama cada ramo representa um elemento, enquanto a raiz representa o agrupamento de todos os elementos. Através do dendogarama e do conhecimento prévio sobre a estrutura dos dados, determinou-se uma distância de corte, para definir os grupos que seriam formados (Doni, 2004). Essa decisão é subjetiva e compete ao estatístico, que conhecendo o objetivo da análise e o número de grupos desejados, realizou este cálculo. Tanto a matriz de similaridade quanto os dendogramas (diagramas bi-dimensionais) criados a partir da análise estatística foram suprimidos desta apresentação, uma vez que não interessavam ao objeto deste trabalho e representavam apenas um meio para se atingir a análise propriamente dita. Além disso, considerou-se o método de agrupamento hierárquico com ligação de Ward, que permite ao estatístico ligar um elemento ao outro até que todos estejam agrupados. Esse tipo de método aglomerativo é mais utilizado quando se aplica a distância euclidiana e quando existem grupos com poucos elementos. (Anderberg, 1973)

Partindo para a análise propriamente, no primeiro agrupamento formado, identificam-se as empresas que receberam os números: 30, 9, 39, 46, 3, 8, 17, 19, 21, 50, 4, 27, 28, 35, 38, 49, 10, 40, 47, 43, 5. Por meio de uma análise descritiva pode-se observar que essas empresas apresentam maior proporção para o tipo Clã $(0,697)$. O segundo grupo é composto pelas empresas: $15,33,41,11,48$ e que conta com maior proporção média para o tipo Inovativa $(0,800)$, seguida do tipo Mercado $(0,720)$. Já o terceiro grupo formado pelas empresas: 1,2 , $37,13,44,32,7,29,42,36,45,23$ apresentou características de cultura do tipo Hierárquica com 0,619. Finalmente, o quarto agrupamento é composto pelas empresas: 20, 24, 14, 6, 31, $25,16,34,18,26,22,12$ e apresenta maior proporção média para a cultura do tipo Mercado com 0,758 .

Considerando esses resultados, o agrupamento 1 receberá a nomenclatura Clã, o agrupamento 2 passa a ser chamado de Inovativa, no terceiro agrupamento a identificação é do tipo Hierárquica e, por fim, para o agrupamento 4 identificamos como tipo Mercado, conforme demonstra a Tabelas 2 . 
Tabela 2: Tipos de cultura para os agrupamentos de empresas

\begin{tabular}{cc}
\hline Grupo & Tipo de Cultura \\
\hline 1 & Clã \\
2 & Inovativa \\
3 & Hierárquica \\
4 & Mercado \\
\hline
\end{tabular}

Fonte: a autora

A partir do agrupamento de empresas por tipo de cultura, conforme demonstrado na Tabela 3, localizada no Anexo C, será possível analisar os resultados da pesquisa no próximo capítulo. Para as questões de comunicação foi realizado um tratamento um pouco diferente da base de dados. Quando o questionário chegou ao tema comunicação, cinco respondentes deixaram de responder ou ignoraram totalmente essa parte, reduzindo a amostra para 45 respostas válidas. Destas 45, nove não responderam ou pularam algumas questões. Assim, foi preciso realizar uma análise estatística com base na possibilidade de questões a serem respondidas e a soma de respostas que demonstravam a prática de Relações Públicas excelentes ou a aplicação dos modelos 3 ou 4, conforme as teorias de Grunig $(1984,1992)$.

Os dados foram interpretados, agregando um ponto à soma, sempre que as respostas coincidiam com a expectativa descrita na análise do roteiro de pesquisa previamente elaborado. Na Tabela 4, localizada no Anexo C, tem-se para cada empresa (ID) o número de perguntas respondidas, a soma de pontos obtidos por cada empresa e a proporção resultante, demostrando que, enquanto algumas empresas obtiveram pontuação baixa (modelos 1 ou 2), outras empresas atingiram pontos próximos do número total de perguntas respondidas (modelos 3 ou 4). E isso pode nos levar a algumas informações importantes. A fim de classificar as empresas com base nas proporções obtidas, também foi realizada uma análise de agrupamento ou cluster, adotando a mesma técnica com distância euclidiana e também empregando o método de agrupamento hierárquico com ligação de Ward.

Dessa forma, foram obtidos dois grupos ou clusters: aqueles que têm práticas próximas aos modelos 1 e 2, e aqueles que têm práticas mais próximas aos modelos 3 e 4 . Assim, tem-se na Tabela 5, localizada no Anexo C, um resumo de cada empresa levando em conta o seu agrupamento. Os grifos na Tabela 5 demonstram as empresas que foram agrupadas no cluster correspondente ao Modelo 1 ou 2. Para facilitar a análise sobre esse tópico, as medidasresumo da proporção, considerando o agrupamento, são apresentadas na Tabela 6 . 
Tabela 6: Medidas-resumo da proporção considerando o agrupamento, sobre o tema comunicação

\begin{tabular}{ccccccc}
\hline Cluster & N & Mínimo & Média & Mediana & Máximo & Desvio Padrão \\
\hline Modelo 1 ou 2 & 8 & 0,167 & 0,278 & 0,261 & 0,417 & 0,073 \\
Modelo 3 ou 4 & 37 & 0,500 & 0,692 & 0,667 & 0,917 & 0,128 \\
\cline { 2 - 6 }$\quad$ Total & 45 & 0,167 & 0,619 & 0,667 & 0,917 & 0,200 \\
\hline
\end{tabular}

Fonte: a autora, com base em análise estatística realizada para a pesquisa

É importante notar que as empresas do grupo "Modelo 1 ou 2" apresentam proporção média 0,278 com desvio padrão de 0,073, ao passo que as empresas do grupo "Modelo 3 ou 4" possuem proporção média de 0,692 e desvio padrão 0,128. Na Figura 3 apresentamos a proporção de cada empresa segundo a análise de agrupamento.

Figura 3: Proporção de cada empresa, segundo o grupo obtido pela análise de cluster.

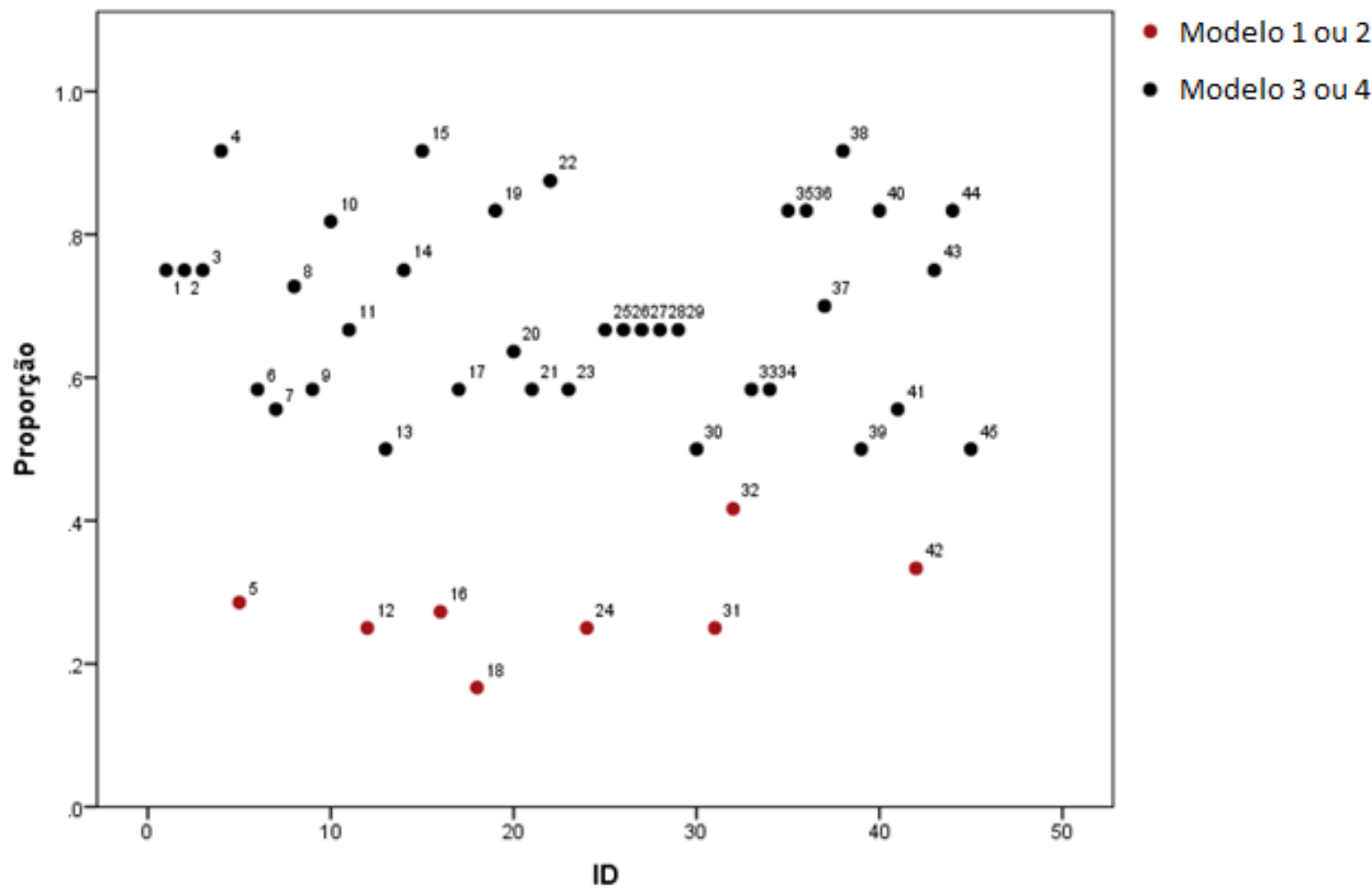

Fonte: a autora, com base em análise estatística realizada para a pesquisa

Na Figura 3, cada ponto corresponde a uma única empresa, completando 45 respondentes sobre o tema comunicação. O índice corresponde à identificação da empresa (ID). Percebe-se pelo gráfico que há uma concentração maior de empresas acima da proporção 5 , que são as 
empresas agrupadas no "Modelo 3 ou 4", ou seja que apresentaram maior número de pontos, de acordo com a análise do roteiro de pesquisa previamente definido (ver Anexo B).

A partir dessa categorização dos dados, tornou-se possível realizar a análise dos resultados obtidos com a pesquisa. As respostas foram categorizadas respeitando os eixos temáticos apresentados no questionário (cultura e comunicação) e também com base nos indicadores delineados na análise do roteiro de pesquisa.

No próximo capítulo faremos a análise dos resultados obtidos e a aplicação desses resultados na matriz de análise. O objetivo é que cada resposta seja enquadrada em um ponto da matriz, permitindo a análise dos resultados como um todo. Assim, espera-se ter um mapa que apresente a visão geral sobre todas as empresas pesquisadas, incluindo pontos de convergência e divergência, que permitam responder às questões propostas no início do trabalho. 


\section{CAPÍTULO 5: Apresentação e análise dos dados}

Este capítulo trata dos resultados encontrados a partir da pesquisa realizada com 50 organizações brasileiras. Após o tratamento de dados e da ordenação das respostas, foi feita uma análise dos temas centrais que foram abordados no questionário de pesquisa: cultura e comunicação. Por fim, os resultados foram interpretados à luz de matrizes de análise, de forma a interagir com as questões de pesquisa, os objetivos propostos e o referencial teórico elaborado como base da dissertação.

\subsection{Matrizes para análise dos dados}

A escolha por desenvolver matrizes para análise dos dados se deu em função das diferentes variáveis da pesquisa e do rigor metodológico necessário para a análise do material obtido. A representação dos resultados na matriz oferece uma síntese visual dos dados coletados, como uma espécie de mapa, que ajuda a organizar e orientar a análise, além de facilitar o entendimento do conteúdo. Para o presente estudo, toda informação obtida após a pesquisa foi categorizada e classificada, de acordo com os dois temas centrais: cultura e comunicação e suas intercorrelações.

A elaboração da matriz de dados passou por três fases. Na primeira fase definimos os parâmetros que embasariam a matriz, decidindo sobre os principais conceitos a trabalhar e sobre como eles seriam mensurados. A segunda fase ocorreu com o preenchimento da matriz, após a análise estatística dos resultados obtidos no questionário. As perguntas do questionário foram relacionadas com os eixos das matrizes de análise, de forma que os resultados obtidos pudessem ser facilmente representados. E, por fim, na terceira fase foi realizada a análise dos resultados a partir das matrizes e fazendo a correlação entre os temas principais da dissertação.

As matrizes propostas são formadas por dois eixos e têm a função de avaliar aspectos da cultura e da comunicação, de acordo com os enfoques teóricos de Grunig (1992), Hosfstede (1994), Cameron e Quinn (2006) e Barros e Prates (1996). O objetivo foi usar a matriz como guia para a interpretação dos resultados. Para tanto, foram considerados três parâmetros que se tornaram os eixos das matrizes:

1. O arcabouço teórico de cultura nacional de Gert Hofstede (1980, 1994, 1997, 2001) e de cultura organizacional de Cameron e Quinn (2006); 
2. Os estudos de James Grunig $(1992,2002)$ e de Grunig e Hunt (1984) que delineiam os modelos da prática comunicacional e da Teoria de Excelência de Grunig et. Al (1992);

3. A análise sobre comportamentos e classificação de um mapa de traços culturais das empresas brasileiras, conduzida por Barros e Prates

As matrizes foram elaboradas a partir dessas bases conceituais, com quadrantes que representam organizações com maior ou menor índice de correspondência a uma determinada dimensão cultural, ou ainda com maior ou menor grau de utilização/aplicação de um modelo de relações públicas, abrangendo os dois principais temas da pesquisa: comunicação e cultura. As matrizes foram construídas com o objetivo de identificar em qual dos quadrantes as instituições pesquisadas se encontram e, assim, permitir o direcionamento da análise dos dados e o enquadramento dos resultados.

Considerando os parâmetros previamente definidos, que estão descritos na análise do roteiro de pesquisa (Anexo B), utilizaremos duas matrizes para análise dos resultados. A Figura 4 representa a matriz desenvolvida para a análise de cultura.

\section{Figura 4: Matriz de análise para cultura - Tipologia de Cultura Organizacional}

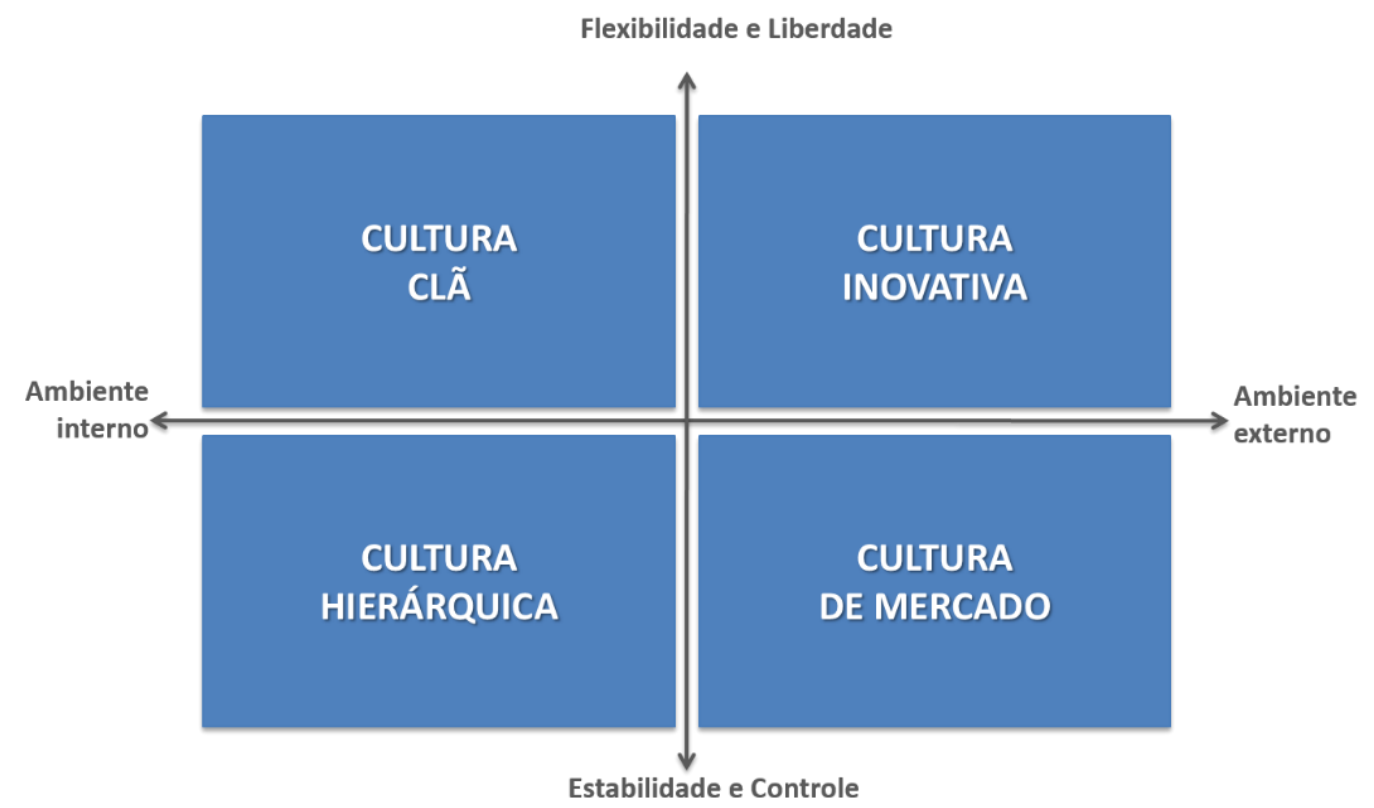

Fonte: Cameron e Quinn (2006, p.50) 
Os estudos de Cameron e Quinn (2006) geraram uma classificação de cultura que foi baseada em evidências empíricas, com método e instrumentos validados em pesquisas para diagnosticar os tipos de cultura organizacional. A tipologia de cultura organizacional de Cameron e Quinn (2006) parte do princípio que as organizações podem ser caracterizadas de acordo com seus traços comuns, apresentando quatro grupos de valores organizacionais: Cultura Clã, Cultura Inovativa, Cultura Hierárquica e Cultura de Mercado.

Para utilização dessa matriz buscamos também parâmetros nas contribuições dos pesquisadores Barros e Prates (1996). Esses dois autores brasileiros entrevistaram 2.500 executivos de 530 empresas e como resultado elaboraram o Modelo de Ação Cultural Brasileiro, que descreve como as estruturas organizacionais brasileiras são influenciadas pelas características e traços culturais do Brasil.

A Figura 5 representa a matriz para análise dos resultados sobre a comunicação. $\mathrm{O}$ parâmetro de modelos de prática de comunicação de Grunig e Hunt (1984), no eixo Y foi considerado importante por representar de forma mais abrangente a face empírica e cotidiana do trabalho realizado por profissionais de comunicação nas organizações.

Como vimos no capítulo sobre fundamentação téorica, Grunig e Hunt (1984) identificaram quatro modelos que descrevem a prática de relações públicas nas organizações: agência de imprensa/divulgação (modelo 1), informação pública (modelo 2), assimétrico de duas mãos (modelo 3) e simétrico de duas mãos (modelo 4) - sendo que, os dois primeiros se caracterizam por uma função mais instrumental, simbólica, tática, midiática e reativa; e os dois últimos representam o caráter mais estratégico, gerencial, comportamental e proativo das relações públicas. 


\section{Figura 5: Matriz de análise para comunicação - percepções sobre a prática de comunicação}

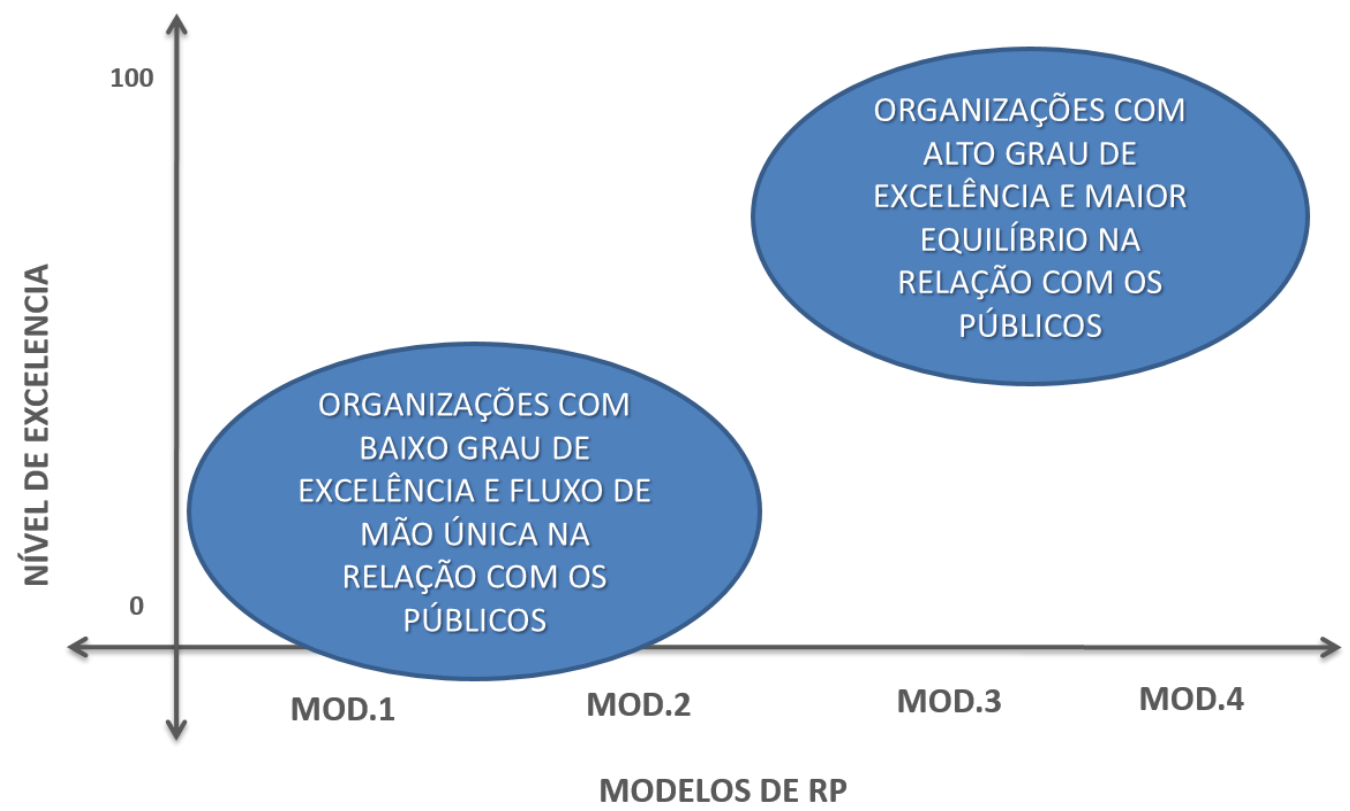

Fonte: elaborado pela autora, com base em Grunig e Hunt (1984) e Grunig et. al. (2002)

Os quatro modelos de Grunig e Hunt (1984) nos ajudam a compreender porque as organizações se comunicam de determinada maneira, em diferentes situações e contextos. Trata-se de uma tipologia universal, que pode ser aplicada, pois oferece bases para a compreender a gestão das relações públicas. Como bem registrou Ferrari (2015), esses modelos têm sido frequentemente utilizados por pesquisadores como eixos de matriz de análise para verificar o comportamento das organizações em diferentes situações.

Além disso, a Teoria da Excelência coordenada por Grunig et. al. (1992), representada no eixo $\mathrm{X}$ oferece dez princípios que regem a prática das relações públicas excelentes. Diferentemente dos modelos de prática de comunicação, os princípios de excelência não são evolutivos e dependem do contexto, da gestão e do entendimento da alta direção da organização. Assim, foi realizada uma seleção dos princípios a serem avaliados, com base no questionário de pesquisa e, ao se identificar a presença de um dos princípios, a organização recebia uma pontuação. Dos 10 princípios existentes na Teoria de Excelência de Grunig et. al. (1992), cinco princípios foram utilizados na presente pesquisa. São eles: o envolvimento do executivo de relações públicas na administração estratégica; a participação direta do executivo de relações públicas junto a alta administração; a função integrada de relações públicas 
mediante o gerenciamento da comunicação interna e externa juntas, no mesmo departamento; as relações públicas como função gerencial separada de outros departamentos e o departamento de relações públicas coordenado por um gestor e não por um técnico.

Ao final da análise estatística para esses cinco princípios obtivemos a proporção de pontos possíveis para cada organização, representando um índice ou nível de excelência. Avaliamos os resultados sobre os temas de comunicação e cultura separadamente e, a seguir foi realizada uma análise dos dois conceitos para observar as correlações existentes nas 50 empresas da amostra. Dessa forma, acreditamos que o uso das matrizes contribuiu para a conseguir verificar os objetivos da dissertação e responder as questões de pesquisa.

\subsection{Perfil da amostra}

Antes de apresentar a análise dos dados obtidos, faremos uma breve apresentação do perfil dos respondentes. A amostra considerada válida para as questões de cultura contou com 50 empresas. Entretanto, das 50 empresas, cinco deixaram de responder apenas as questões de comunicação, na segunda parte do questionário. Assim, 45 empresas foram a amostra considerada válida para as questões de comunicação.

Como mencionado no capítulo sobre os procedimentos metodológicos, as empresas que compõem a amostra representam diferentes setores da economia; o segmento industrial contou com $32 \%$ das respostas válidas, seguido do setor de serviços com $16 \%$ e de empresas públicas ou órgãos governamentais com $12 \%$ da amostra.

Entre as indústrias, $40 \%$ atuam no segmento B2B (business to business), 24\% atuam no B2C (business to consumer) e $16 \%$ em ambos os segmentos. Ao considerar a localização das empresas, a maioria encontra-se na região Sudeste (82\%), seguida pela região Sul (8\%) e região Nordeste $(4 \%)$.

De forma geral, podemos considerar que a amostra é composta por empresas de médio ou grande porte, uma vez que $62 \%$ afirmaram ter acima de mil funcionários ${ }^{7}$. Com a identificação dessas empresas, foi realizada uma busca por seus nomes no ranking do Guia Exame - Maiores \& Melhores (2015). Após essa checagem, identificamos que $60 \%$ delas fazem parte da lista das 500 maiores empresas do Brasil.

\footnotetext{
${ }^{7}$ Foi considerado o critério de número de funcionários, utilizado pelo SEBRAE, para seleção da amostra, sendo de médio porte as organizações com 100 a 499 empregados e de grande porte as organizações com mais de 500 empregados.
} 
$30 \%$ dos respondentes tinham cargo de diretor de comunicação. Somando as respostas dos gerentes, que também é um cargo de liderança, totalizamos $62 \%$ de respostas provenientes do alto escalão da comunicação das empresas. Além disso, $58 \%$ dos respondentes têm mais de 35 anos, sendo que, 24\% estão acima dos 45 anos. Importante destacar que $76 \%$ dos respondentes têm curso universitário e destes e 54\% com pós-graduação lato sensu e $16 \%$ stricto sensu. A área de comunicação é a principal formação dos respondentes, correspondendo a 88\%; destes $44 \%$ afirmaram ter formação em Relações Públicas. A segunda formação mais mencionada entre os respondentes foi Jornalismo, seguida por Administração, com $8 \%$.

Com relação à estrutura hierárquica, 60\% dos respondentes afirmaram se reportar para o mais alto nível na organização, ou seja, o Presidente, CEO ou Conselho de Administração. A pesquisa mostrou também que $11 \%$ da amostra responde à área de Recursos Humanos e outros 6\% se reporta ao Marketing/área comercial. Considerando critérios como cargo, reporte hierárquico, experiência e grau de instrução é possível afirmar que se trata de uma sondagem realizada com amostra que atende às necessidades da pesquisa e que tem condições de responder aos objetivos do trabalho.

A respeito do tamanho da área de comunicação os respondentes informaram que $60 \%$ das empresas contam com até cinco profissionais. Em 16\% da amostra, a área de comunicação conta com 11 a 20 profissionais, e 10\% das empresas têm entre 21 e 30 pessoas na área. Ao analisarmos estes dados sobre o tamanho da área de comunicação juntamente com a informação do porte da empresa, percebe-se que a pesquisa foi respondida por empresas de grande porte, mas que têm estruturas de comunicação pequenas. Este fato pode ser também um reflexo do momento econômico do país, que como visto no capítulo 1, acabou por gerar impactos diretos sobre o emprego e as atividades de comunicação, principalmente nas grandes e médias empresas.

O questionário avaliou também o nível de terceirização das atividades de comunicação na empresa. Para 58\% dos respondentes poucas atividades são terceirizadas, a maior parte das tarefas é realizadas in house. De toda a amostra consultada, 6\% afirmou não terceirizar nenhuma atividade e, por outro lado, $20 \%$ terceiriza total ou parcialmente as atividades de comunicação. A seguir, são apresentados os resultados das duas dimensões avaliadas na pesquisa, a cultura e a comunicação. 


\subsection{Cultura Clã é o tipo cultural predominante nas organizações pesquisadas}

Os resultados da pesquisa demonstram que $40 \%$ das empresas podem ser classificadas como do grupo da Cultura Clã. Em pesquisas anteriores, as descrições da tipologia de cultura de Cameron e Quinn (2006) e de Barros e Prates (1996) já demonstravam que a cultura do tipo clã seria a mais próxima da realidade brasileira, com seus traços bastante característicos e coincidentes, envolvendo flexibilidade, relações harmoniosas, criação de vínculos de pai e filho entre patrão e empregado, lealdade pessoal e personalismo. E, por outro lado, também estão presentes traços como paternalismo, concentração de poder, postura de espectador e tendência a evitar conflitos.

De acordo com Cameron e Quinn (2006), organizações mais voltadas para o ambiente interno, como é o caso das que apresentam cultura do tipo Clã, valorizam flexibilidade, adaptabilidade à mudanças e discrição. Segundo a tipologia de cultura, essas características demonstram o que as pessoas valorizam na performance da organização e que, de uma forma ou de outra, descrevem com precisão os principais tipos da gestão organizacional presentes na empresa.

Para Tanure (2005), essas características estão enraizadas na história recente do país e são o resultado do projeto de colonização portuguesa que estabeleceu organizações rígidas e hierarquicamente bem definidas, explorou as riquezas naturais e a terra por meio de um regime de escravidão. A autora acredita que alguns dos elementos sociais que, naquela época foram introduzidos na formação da sociedade brasileira rural e agrícola influenciaram a sociedade urbana e industrial e também o modo como as empresas foram e, ainda são administradas.

Fleury e Fleury (2012) registram que a história da industrialização brasileira foi marcada por acontecimentos que também fortaleceram esses traços, como a chegada de imigrantes europeus e japoneses ao país e a formação de empresas com a contribuição de famílias inteiras. Esses dois fatores combinados levaram à criação de grandes grupos empresariais brasileiros, como é o caso de Gerdau (empresa familiar criada por imigrante alemão), Votorantim (empresa familiar, que teve início a partir da aquisição de uma fábrica por 
imigrantes portugueses), Brahma (fundada por imigrante suíço) e a Antarctica (fundada por imigrante português), entre outras.

Além das origens históricas, acontecimentos sociais e políticos também acabaram por marcar a cultura organizacional no país. $\mathrm{Na}$ década de 40, quando foi sancionada a primeira legislação trabalhista brasileira, o governo desempenhava um papel ativo e assumia a causa da industrialização como símbolo do progresso no país. Trata-se de uma legislação de cunho populista, que vai ao encontro do pensamento paternalista dos empresários da época, segundo Fleury e Fleury (2012).

O tradicional modelo brasileiro de gestão prevaleceu até o final dos anos 80 e foi compatível com o mercado doméstico protegido e dependente das ações do governo. Esse modelo ajudou a estabelecer uma mentalidade "paroquial" nas empresas, com estilo empreendedor voltado para o mercado interno e desprovido de visão global. Foi a partir da década de 90 que o sistema produtivo brasileiro passou por uma reestruturação com a abertura do mercado interno às empresas estrangeiras e a desestatização de alguns setores da indústria. Em termos históricos, é uma mudança recente que ainda gera impactos sobre a cultura e a atuação das empresas.

Como vimos, a Cultura Clã é caracterizada pela centralização de decisões até em níveis hierárquicos mais elevados, limitando a tomada de decisão, a responsabilidade e autonomia daqueles que estão em níveis hierárquicos mais baixos. Isso não impede que a flexibilidade e adaptabilidade à mudanças seja uma característica presente nesse tipo de cultura. Em geral, os brasileiros são acostumados a lidar com ambientes turbulentos, onde a tomada de decisão é incerta. Segundo Cameron e Quinn (2006), para lidar com isso no ambiente corporativo, as empresas acabam por incentivar o compartilhamento de crenças, valores e metas, envolvendo todos no mesmo "ideal".

A esses traços culturais agregamos também a visão informal e imediatista do líder, com foco em resultados de curto prazo e a falta de planejamento estratégico, que acabam por descrever o perfil do patriarca nas organizações brasileiras. São traços muito fortes, que delimitam atitudes e determinam ações dentro das empresas. 
Dessa forma, $40 \%$ das empresas da pesquisa contam com o perfil da Cultura Clã e que condiz com a realidade cultural das organizações brasileiras, descrita por Cameron e Quinn (2006), Barros e Prates (1996) e Tanure (2005, 2009) e Hofstede (1997), todos citados nos primeiros capítulos desse trabalho. A Figura 6 apresenta a tipologia de cultura de Cameron e Quinn (2006) com as empresas respondentes identificadas como de Cultura Inovativa, de Mercado, Hierárquica e Clã segundo e o posicionamento das organizações pesquisadas no tipo cultural correspondente.

Figura 6: Matriz da tipologia de cultura organizacional com aplicação do resultado por empresa pesquisada

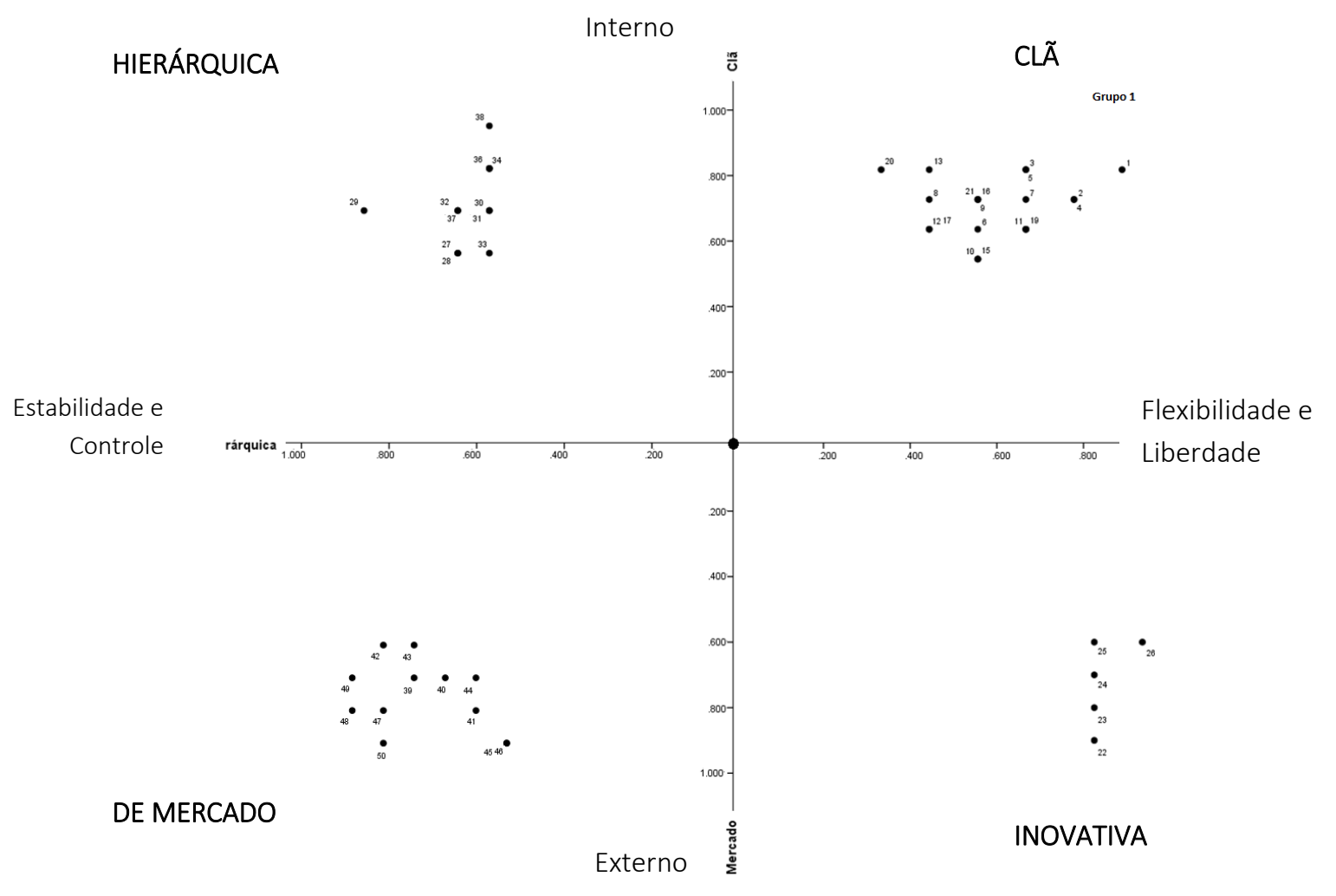

Fonte: A autora, com base em Cameron e Quinn (2006, p.50)

No primeiro quadrante (lado direito superior) é apresentado o gráfico de dispersão entre as proporções das culturas Inovativa e de Clã. Já no segundo quadrante (lado esquerdo superior) tem-se a dispersão entre as proporções de culturas Hierárquica e de Clã. O terceiro quadrante (lado esquerdo inferior) é apresentado o gráfico de dispersão entre as proporções de culturas Hierárquica e de Mercado. E, finalmente, no quarto quadrante (lado direito inferior) é apresentado o gráfico de dispersão entre as proporções de cultura Inovativa e de Mercado. 
Como se observa, somente $10 \%$ empresas da amostra localizaram-se no quadrante de Cultura Inovativa, o que demonstra que a pesquisa contou com poucas organizações com perfil mais centrado em inovação e empreendedorismo. É possível supor que nesse grupo estão as empresas da área de tecnologia, do setor de serviços, cuja ênfase está voltada para a aquisição de novos conhecimentos, conforme delimitou a teoria de Cameron e Quinn (2006). De acordo com a tipologia cultural de referência, essas empresas demonstram se posicionar mais para o ambiente externo, se preocupam mais com a imagem que transmitem e se caracterizam por traços culturais como a flexibilidade e liberdade.

Por outro lado, $40 \%$ da amostra pesquisada está posicionada no quadrante das empresas de Cultura Clã, confirmando a teoria de que a cultura brasileira combina traços paternalistas e centralizados em autoridade, mas, ao mesmo tempo com algum espaço para lealdade, tradicionalismo, flexibilidade e criatividade. Cameron e Quinn (2006) descrevem esse tipo de cultura como de empresas coesas, que compartilham seus valores e seus objetivos, estimulam a participação, o trabalho em equipe e o envolvimento dos funcionários, se parecendo mais com entidade familiares do que com instituições econômicas.

Tanure (2005) reforça essas características, ao afirmar que no Brasil os relacionamentos acompanham a tradição familiar. Nas empresas brasileiras é comum encontrar uma situação em que o líder dá proteção ao liderado e o liderado assume deveres morais de obediência e reverência para com o líder, quase que fazendo o papel de mentor ou se confundindo com um membro da família. É um comportamento típico da Cultura Clã. O processo decisório é centralizado na cadeia hierárquica e a cultura de concentração de poder não deixa dúvidas sobre quem é o responsável pela decisão e nem sobre quem deve implementar o que foi decidido.

Na pesquisa realizada por Hofstede (1980), o Brasil já aparecia entre os países com alto grau de centralização de poder e altas expressões de dependência em relação aos superiores, características similares as que são descritas como comuns à Cultura Clã, de acordo com tipologia cultural de Cameron e Quinn (2006). Nos países com maior distância hierárquica, segundo Hofstede (1980), a desigualdade entre as pessoas é vista com mais naturalidade do que em países desenvolvidos e aqueles que têm menos poder dependem dos mais poderosos e 
a hierarquia nas organizações reflete exatamente a desigualdade existente na sociedade, como é o caso do Brasil. Enquanto os subordinados esperam que seus líderes lhes digam o que fazer, o líder ideal nesse tipo de cultura é um autocrata benevolente, com o desafio de empoderar os funcionários, facilitando a participação, o comprometimento e a lealdade para conseguir manter seu negócio no mercado (Cameron e Quinn, 2006).

A pesquisa intercultural que embasou os estudos de Tanure (2005) e entrevistou 2.500 executivos de 530 empresas demonstrou como isso se reflete nas estruturas organizacionais brasileiras: elas são influenciadas pelas características de concentração de poder e pelo personalismo, levando a um modelo funcional acentuadamente piramidal e integrado no nível hierárquico mais elevado. O sentimento patrimonialista e o patriarcalismo falam mais alto, gerando uma centralização do poder decisório na figura do líder que, dentro da Cultura Clã, é o chefe de todos.

Na pesquisa realizada por Tanure (2005) $66 \%$ dos brasileiros acreditavam que a estrutura hierárquica era necessária para saber quem tem autoridade sobre quem e $88 \%$ concordaram com a existência da concentração de poder em suas empresas. Isso confirma também os traços da Cultura Clã, em que os profissionais se habituam e se acomodam aos moldes da relação autoritária, pois têm receio de tomar iniciativas e correr riscos. No dia a dia das organizações, não é raro perceber como as profissionais têm dificuldades em atuar numa estrutura com mais de um chefe, pois enxergam a empresa como a extensão da sua família.

Retomando a análise da Figura 6, podemos perceber também um equilíbrio entre as empresas alocadas no quadrante da Cultura Hierárquica e a Cultura de Mercado, uma vez que cada uma delas conta com $25 \%$ da amostra pesquisada. O traço principal que une essas empresas é a estabilidade e controle que, como vimos são características muito presentes nas organizações brasileiras. O que diferencia as empresas que estão representadas nesses dois tipos culturais é a visão de mercado: enquanto as empresas situadas no quadrante de Cultura Hierárquica têm uma visão de mercado mais voltada para o ambiente interno, como é o caso de agências de governo e empresas da iniciativa pública, as organizações localizadas no quadrante de Cultura de Mercado voltam suas atenções para o ambiente externo, como empresas de bens de consumo, por exemplo. 
Dessa forma, entende-se que a amostra de empresas pesquisadas foi diversa, contribuindo com tipos distintos de cultura. Fica claro que a Cultura Clã foi a cultura dominante, com maior número de empresas no quadrante e, conforme demonstrado pelos autores do referencial teórico, esse realmente é o tipo cultural mais próximo da realidade organizacional brasileira. Mesmo após mais de dez anos que Tanure (2005) revisitou o trabalho de Hofstede (1987), é perceptível que pouco mudou em relação a gestão de empresas e aos traços culturais brasileiros. Assim, atendemos a um dos objetivos iniciais dessa dissertação que era identificar traços culturais presentes em organizações brasileiras. Na sequência analisaremos os dados encontrados na pesquisa para o tema da comunicação.

\subsection{Organizações pesquisadas praticam comunicação estratégica e baseada nos princípios de excelência}

A pesquisa demonstrou que $82 \%$ das empresas pesquisadas estão mais próximas do modelo assimétrico de duas mãos (modelo 3) e do modelo simétrico de duas mãos (modelo 4). Os resultados apontam ainda que $18 \%$ das empresas exercem uma comunicação mais próxima do modelo agência de imprensa (modelo 1) e do modelo informação pública (modelo 2), de acordo com a teoria dos modelos de Relações Públicas de Grunig e Hunt (1984).

Conforme descrito no início deste capítulo, ao categorizar as empresas por práticas que correspondam aos princípios de Excelência de Grunig (1992) encontramos cerca de $78 \%$ de empresas com altos índices de excelência e apenas $22 \%$ que registraram baixos índices de excelência. À primeira vista, isso nos mostra que as empresas pesquisadas parecem priorizar relacionamentos de mão dupla, realizar atividades simétricas de comunicação e relações públicas excelentes.

Ainda que a pesquisa tenha sido respondida pelos próprios profissionais responsáveis pela área de comunicação, a percepção é que eles compreendem bem seu papel para contribuir com a gestão estratégica nas empresas onde atuam. O resultado da pesquisa nos permite inferir que, nas empresas pesquisadas, o processo de comunicação é simétrico, de mão dupla e prioriza a participação dos executivos da área de comunicação nos processos de decisão. Entretanto, há variações e matizes que devem ser analisadas. 
Ao serem perguntados se as divulgações externas realizadas pela área de comunicação tinham como principal objetivo promover a organização, $81 \%$ dos profissionais consultados disseram que sim. Esta é uma característica do modelo agência de imprensa ou do modelo de informação pública, cujo fluxo de comunicação é de mão única e prioriza a disseminação de conteúdo relevante para a empresa e não necessariamente para seus públicos de interesse. Dessa forma, podemos entender que, por mais que acreditem praticar uma comunicação de mão dupla, em determinadas situações de vulnerabilidade no ambiente externo ou por algum impedimento interno (por exemplo, questões jurídicas, financeiras, restrições de investidores, etc.) os profissionais pesquisados também utilizam ferramentas para promover seus produtos e serviços, de forma objetiva, priorizando fluxos assimétricos (modelos 1 e 2)

Por outro lado, $75 \%$ dos entrevistados responderam que o trabalho de comunicação realizado nas empresas pesquisadas produzem relacionamento de longo prazo e $76 \%$ dos respondentes resumiram as ações de comunicação realizadas como um processo contínuo e permanente, que contribui para alavancar a reputação positiva da empresa frente à sociedade. Essas duas condutas estão mais alinhadas aos modelos simétricos do que aos fluxos assimétricos de comunicação.

Além disso, 79\% dos profissionais consultados afirmaram que as ações de comunicação realizadas são fruto de um trabalho planejado para atingir objetivos estratégicos para a organização, demonstrando que estão mais em linha com a prática da comunicação de mão dupla, contribuindo para a gestão estratégica. Outro resultado que merece ser destacado é que $87 \%$ dos entrevistados afirmaram que a comunicação praticada na empresa busca equilibrar os interesses econômicos com os interesses dos públicos com os quais a organização se comunica, com o objetivo de cultivar e manter bons relacionamentos.

Estes resultados aparentemente divergentes demonstram que as organizações exercem atividades combinando práticas do modelo agência de imprensa e do modelo simétrico de duas mãos. Segundo Ferrari (2011) a combinação de táticas assimétricas e simétricas pode parecer paradoxal, porém, na prática ela ocorre dependendo da situação que a organização enfrenta, principalmente quando o que está em jogo o equilíbrio dos relacionamentos entre a empresa e seus públicos. Isso reforça também o fato de que os modelos não são paradigmas em que as organizações se encaixam ou não se encaixam. Ao contrário, os modelos podem 
coexistir, dependendo do momento e do contexto da empresa (Ferrari, 2011). A empresa pode adotar características de um modelo, em determinado contexto e em outra situação utilizar outro modelo, conforme sua necessidade.

Independentemente do modelo de relacionamento que utilizam, os profissionais pesquisados demonstram ser capazes de intervir no comportamento da organização no relacionamento com seus públicos de interesse. Segundo os princípios da Teoria da Excelência de Grunig (1992), para que essa intervenção ocorra realmente é necessário que o representante da comunicação seja membro da coalizão dominante da organização e se reporte diretamente aos diretores executivos que pertencem a ela. Os resultados da pesquisa nos mostram que a maioria das empresas contam com estruturas de comunicação muito próximas da alta administração das empresas e $60 \%$ dos profissionais afirmaram ter reporte direto ao Presidente/CEO.

Nesse mesmo sentido, $77 \%$ dos entrevistados acreditam que quanto mais a área de comunicação estiver próxima da presidência, mais estratégicas são as ações da comunicação e melhor a área pode apoiar as realizações da empresa. Ou seja, os respondentes são conscientes da importância da posição que ocupam para que a comunicação seja uma função efetivamente estratégica.

Como vimos na análise, $68 \%$ dos entrevistados afirmam terem cargos de chefia ou gerência, dados que os credenciam como responsáveis pela comunicação que é praticada na empresa. A pesquisa mostrou ainda que $88 \%$ dos profissionais têm formação em comunicação e $76 \%$ já passaram por cursos de pós-graduação, o que, segundo Grunig (2011) lhes concede recursos diferenciados e próprios para implementar programas de comunicação excelentes, alinhados com os objetivos da organização. Ter profissionais qualificados é mais um ponto que corresponde a um dos princípios de Excelência: o departamento de comunicação deve ser chefiado por um gerente e não por um técnico e, além disso, o alto executivo de Relações Públicas deve ter o conhecimento necessário para o papel gerencial para que possa exercer sua função como estrategista da comunicação (Grunig, 2011).

Esse resultado reforça também a importância da comunicação ser exercida por um departamento que integre todas as funções da área e seja dedicado apenas à comunicação. Exatamente $76 \%$ dos entrevistados afirmam que tanto a comunicação interna quanto a 
comunicação externa são praticadas em um mesmo departamento na empresa. De acordo com os princípios de relações públicas excelentes, esse é um traço que caracteriza empresas com a função de comunicação integrada, reunindo na mesma área programas de comunicação que atendam a diferentes públicos, mas com uma base estratégica unificada. A Teoria da Excelência de Grunig (1992) preconiza que, mesmo que a função de relações públicas seja integrada numa organização excelente, a área de comunicação não deve estar subordinada a outro departamento cuja responsabilidade primeira não seja relacionada à comunicação.

Outro ponto importante é que o modelo de relações públicas praticado define o papel e as funções a serem desempenhadas pelos profissionais de comunicação. Portanto, a tipologia dos modelos de prática de relações públicas continua sendo um parâmetro muito utilizado por pesquisadores para 'medir' o processo da atividade nas organizações. Empregada como um continuum, ela ajuda o pesquisador a 'localizar' as práticas das organizações nos modelos teóricos apresentados por Grunig e Hunt (1984). Dessa forma, é possível o uso de uma teoria para explicar como funciona a comunicação no mundo real.

Exatamente buscando trazer os resultados encontrados para a realidade das empresas pesquisadas, aplicamos a matriz apresentada na Figura 7, que oferece um mapa das organizações e a localização de cada uma delas frente às duas teorias de comunicação que embasaram o trabalho. 
Figura 7: Matriz de comunicação com aplicação do resultado por empresa pesquisada

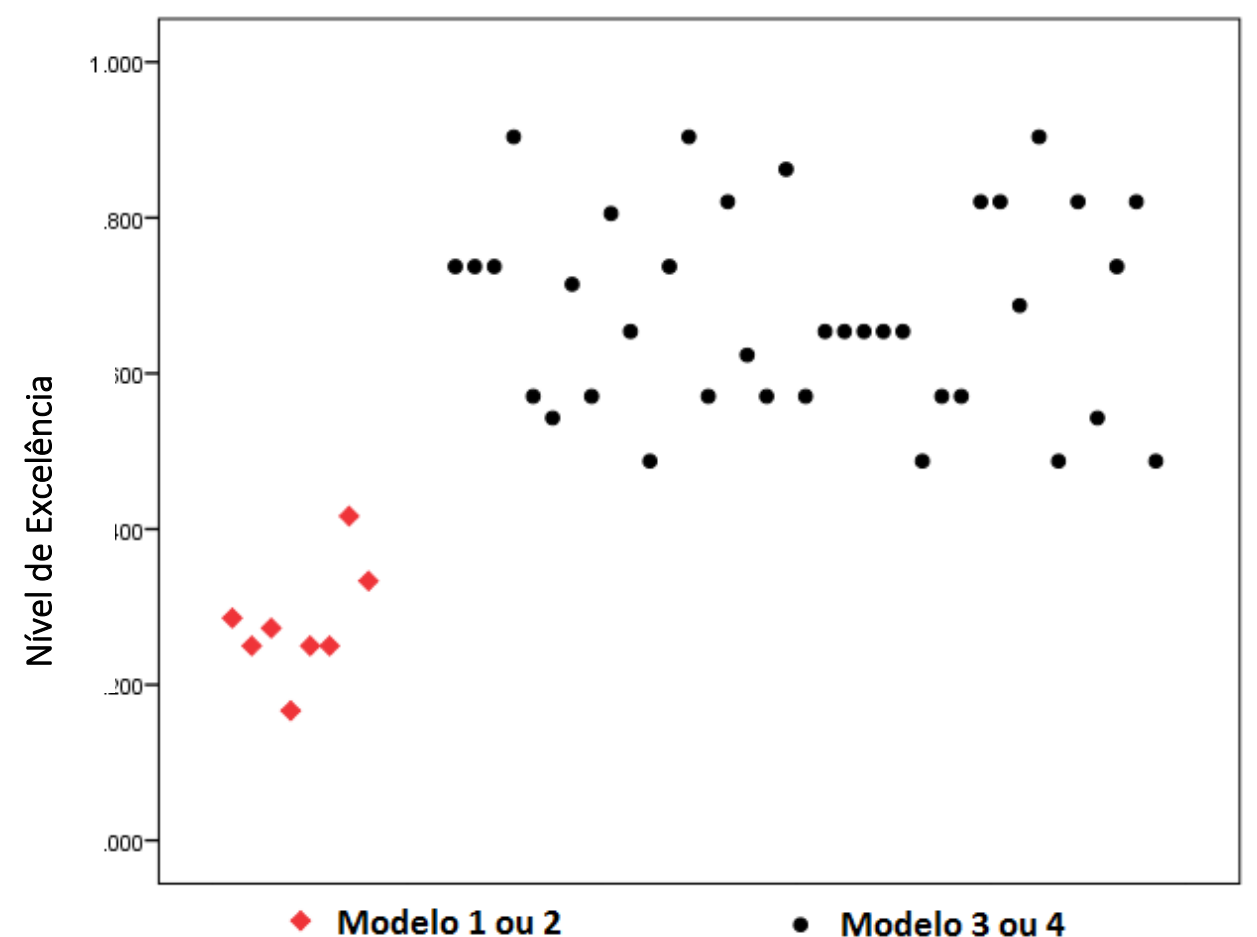

Fonte: a autora, com base em Grunig e Hunt (1984) e Grunig (1992).

Na Figura 7, os pontos em vermelho mostram as organizações que, em função das respostas dadas na pesquisa, foram identificadas como mais próximas dos modelos assimétricos e com pontuação que demonstraram baixos níveis de acordo com os princípios de excelência. Já os pontos em preto correspondem às organizações que, em maior ou menor grau, estão mais próximas dos modelos 3 ou 4 e, ainda, com pontuações altas no que diz respeito aos princípios de excelência. A Figura 7 reforça que a maior parte das organizações pesquisada está posicionada próxima aos modelos 3 e 4, com índice de pontos que representam boa aplicação dos princípios de excelência.

Em seus resultados de pesquisa, Ferrari (2000) concluiu que o modelo de relações públicas praticado nas organizações sempre é resultado do contexto cultural, da vulnerabilidade do ambiente, dos modelos de gestão praticado pela organização e dos valores compartilhados que ocorrem no interior da organização, assim como das demandas externas que pressionam ou oferecem oportunidades. Por isso, acreditamos que o exercício da comunicação está diretamente conectado à cultura e comportamentos culturais das organizações e/ou indivíduos. 


\subsection{Comunicação e Cultura: as duas principais variáveis da pesquisa}

Um dos objetivos iniciais deste trabalho era verificar se a cultura organizacional interfere na prática da comunicação nas empresas. Assim, procurando atender a esse objetivo, os resultados da pesquisa apontaram que $87 \%$ dos profissionais consultados afirmaram que a cultura do país e a cultura da organização têm influência sobre as ações e processos de comunicação na empresa.

Ainda que a pesquisa seja considerada apenas uma sondagem, encontrar profissionais que tenham consciência sobre essa influência é legítimo e demonstra que os respondentes são conhecedores dos desafios de aproximar a comunicação da cultura organizacional. Mais do que isso, esses profissionais parecem compreender que uma das características que fazem do relações públicas um profissional estrategista é exatamente assumir a gestão da comunicação em todas as suas dimensões, incluindo o fortalecimento dos elementos que compõem a identidade e dos valores culturais da organização (Ferrari e Moura, 2015).

Vercic e Grunig (1996) compartilham desse entendimento, ao afirmar que a cultura é uma das mais importantes aplicações específicas, uma vez que tem uma relação direta com o processo de comunicação. Por isso, a identificação do ambiente cultural é fundamental para organizações e para os profissionais que nela atuam. Como já abordado nos capítulos iniciais, uma situação de conflito ou até mesmo um mal entendido cultural pode gerar problemas de comunicação entre funcionários, por exemplo, ou entre a organização e uma comunidade.

Curioso notar que ao longo da pesquisa realizada, a Cultura Clã foi avaliada nas questões e, ao cruzar os resultados de cultura e de comunicação, percebeu-se que as empresas com práticas de comunicação que seguem o fluxo simétrico ou o assimétrico de duas mãos apresentaram o maior índice de respostas favoráveis a esse tipo de cultura. Vamos detalhar melhor esses resultados a seguir.

Como vimos, um traço típico da cultura organizacional brasileira é o "evitar conflito". Ora, evitar o conflito não significa que ele não exista. É curioso notar que, embora os brasileiros geralmente demonstrem suas emoções com facilidade, no ambiente organizacional eles não revelam abertamente os conflitos. Segundo Tanure (2005), nas empresas brasileiras, os 
conflitos são identificados, mas não tratados direta e abertamente e a solução encontrada envolve muitas vezes um intermediário ou mediador.

Isso indica claramente que há um espaço para a comunicação atuar, oferecendo ferramentas para dar conta do conflito, abrir canais de diálogo, promover o entendimento ou simplesmente informar temas polêmicos, parte da rotina no âmbito corporativo. $\mathrm{O}$ que não é dito pelo liderado diretamente ao seu chefe pode ser transmitido à área de Recursos Humanos por meio de uma caixa de sugestões online ou de um encontro informal como o "Café da manhã com o presidente", por exemplo.

Observamos ainda que os resultados encontrados a partir do cruzamento dos dados sobre cultura e sobre comunicação demonstram que empresas classificadas como mais próximas do fluxo simétrico de comunicação (modelos 3 e 4) tendem a valorizar a lealdade e a confiança entre os colegas, com o objetivo de manter bons relacionamentos, características que de acordo com Cameron e Quinn (2006) identificam a Cultura Clã.

De acordo com os resultados encontrados, estas características estão presentes nas empresas de $65 \%$ dos respondentes identificados como dos modelos 3 e 4 . Da mesma forma, empresas que consideram importante o incentivo à participação e o desenvolvimento dos funcionários, buscam o modelo de comunicação de mão dupla. Trabalho em equipe, comprometimento e participação são características das empresas de $65 \%$ dos respondentes dos modelos de comunicação 3 e 4, e não estão presentes na realidade de $57 \%$ dos respondentes dos modelos 1 e 2. Segundo Cameron e Quinn (2006), a empresa do tipo Cultura Clã valoriza os benefícios de longo prazo para o desenvolvimento individual e o sucesso é definido pelo clima interno e pelo comprometimento dos funcionários. Utilizando a mesma perspectiva para essa análise, identificamos dados da pesquisa que demonstram que vender mais, produzir a baixo custo e ser líder de mercado são sinônimos de sucesso nas empresas de $75 \%$ dos respondentes mais próximos dos modelos de comunicação 1 e 2 . Assim, podemos inferir que estruturas mais rígidas e centralizadas que apontaram a preocupação em seguir regras pré-definidas e realizar as tarefas, tendem a apresentar características de comunicação próximas do modelo de agência de imprensa. 
Segundo Tanure (2005), ao mesmo tempo em que os representantes da cultura organizacional brasileira dão grande importância a uma boa relação com o líder, eles estão bem atentos às posições de poder, à manutenção dos relacionamentos, e acabam se comportando como a organização espera, inclusive do ponto de vista da comunicação. Quando perguntados sobre o incentivo dos superiores ao trabalho realizado, $70 \%$ dos respondentes de empresas com práticas próximas aos modelos 3 e 4 reconheceram esse incentivo e mais de $80 \%$ dos respondentes de empresas dos modelos 1 e 2 não concordaram com a existência do incentivo.

Segundo Cameron e Quinn (2006), a Cultura do tipo Clã é reconhecida por um ambiente agradável, onde as pessoas compartilham muito de si e entendem a empresa como uma extensão da família. Os autores acreditam que os líderes dessas culturas são vistos como mentores ou até mesmo parentes. E isso pode ser identificado na pesquisa: para $61 \%$ dos representantes dos modelos 3 e 4 de comunicação, a empresa onde trabalham se parece mais com uma família, onde os colegas compartilham experiências pessoais. Por outro lado, $62 \%$ dos entrevistados, que estão mais próximos dos modelos 1 e 2, dizem que a empresa onde trabalham não se parece com uma família.

A concentração de poder é um dos eixos estruturantes da cultura brasileira. Diferentes fontes de pesquisa (Hofstede, 1987, Tanure, 2005, Ferrari, 2011), além dos dados que foram obtidos, demonstram a tendência à concentração do poder nas empresas, o que leva a outros dois traços: postura de espectador e a tendência a evitar conflitos. Uma vez que os líderes têm características dominadoras, o liderado se acanha, não potencializado sua contribuição para a organização. Há, portanto, mais uma oportunidade para a comunicação atuar de forma estratégica. Sabendo da presença desse traço entre os funcionários, a área de comunicação pode propor atividades para estimular a participação e oferecer ferramentas que minimizem o eventual efeito negativo para os resultados.

Segundo Tanure (2005), mesmo numa situação de impasse, o brasileiro trata de forma indireta seus inimigos declarados, lançando mão muitas vezes da fofoca e evitando o confronto emocional. Percebe-se, portanto, mais um ponto de conexão com as atividades de comunicação organizacional. No ambiente corporativo, os relações públicas devem ser capazes de ler e compreender traços culturais, normas e tabus. $\mathrm{O}$ entendimento mais apurado 
desse cenário pode ser desenvolvido ao se analisar a cultura organizacional, os costumes, os comportamentos e as leis, que muitas vezes não estão escritas ou declaradas.

Como é possível observar, os desafios das Relações Púbicas aumentam à medida que as diferenças culturais entre organizações e seus públicos se tornam mais exacerbadas (Allien e Dozier, 2012). Sendo assim, fica cada vez mais claro o papel estratégico do profissional de comunicação, principalmente no sentido de construir e preservar o valor da marca, mas também de estabelecer relacionamentos de longo prazo com os públicos estratégicos (Ferrari e Moura, 2015), e mais além, dedicar-se para as questões do contexto cultural, que envolvem desde adequação de estratégias para adaptar-se a novas realidades ou ambientes diversos até lidar com influências da cultura no cotidiano das organizações.

Na sequência, retomamos as questões de pesquisa e procuramos respondê-las com base nas informações apuradas.

\subsection{Análise das questões de pesquisa da dissertação}

1) Quais são as características culturais brasileiras que influenciam a cultura organizacional?

A partir do resultado da pesquisa é possível afirmar que existem três traços culturais que estão presentes e influenciam diretamente a gestão e a cultura organizacional brasileira: o poder, as relações e a flexibilidade. O poder determina o comportamento das pessoas, dentro e fora do ambiente empresarial. Os brasileiros são acostumados a se submeterem à autoridade sem questioná-la e, além disso, valorizam a hierarquia e convivem naturalmente com a concentração de poder presente na cultura brasileira.

O Brasil está mais próximo das sociedades que valorizam o relacionamento entre as pessoas do grupo, por isso, pode ser considerado um pais coletivista. Identificou-se que, entre as empresas pesquisadas, há o predomínio da cultura de Clã, que caracteriza-se pela postura participativa da liderança e a lealdade na relação entre líderes e liderados. Ambiguidade nas regras e normas, tendência a tomar posturas políticas e a utilizar a prática de dividir para governar são algumas expressões que definem bem comportamentos presentes em organizações desse tipo. 
Em geral, culturas com essas características dependem de redes de amizades, de velhos companheiros e camaradas. Nessas culturas, que combinam alto índice de concentração de poder com baixo individualismo e são típicas dos países com maior distancia hierárquica, quando existem problemas mudam-se as pessoas.

Flexibilidade, criatividade e adaptabilidade também estão presentes e dão o tom dos relacionamentos e da forma como as situações de conflito são resolvidas. Para tudo se dá um “jeitinho". Em função dessas características, as empresas com esse tipo de cultura demonstram uma notável habilidade de se ajustarem aos altos e baixos da economia, às alterações de governos e políticas. A adaptabilidade e criatividade também são valorizadas nos funcionários, para que possam superar eventuais obstáculos nas organizações.

Em resumo, podemos afirmar que existe um estilo predominante nas organizações pesquisadas, diferente do estilo de outros países com histórias, culturas e características distintas. Esse estilo é marcado por traços familiares fortes e grande capacidade de lidar com a incerteza, além da flexibilidade e criatividade, que incorporam leveza e comprometimento ao perfil dos líderes das empresas.

\section{2) De que forma as questões culturais interferem na prática de comunicação das empresas?}

Vimos que o estilo de gestão de uma empresa, revela seu caráter, sua identidade e seu DNA, mas também, é influenciado pela cultura do país ou local de origem da empresa. Por isso, a visão sobre a cultura organizacional não se limita à observação de elementos superficiais, mas deve incluir a interação entre os membros para o entendimento real do seu significado (Fleury e Fleury, 2012). A partir dos resultados apurados, percebemos que essa interação entre os membros das empresas reflete todas as formas possíveis de comunicação e relacionamento, envolvendo a empresa, seus funcionários, clientes e parceiros.

Vercic e Sriramesh (2003) argumentam que a área de Relações Públicas, que sempre foi tradicionalmente associada à comunicação e ao jornalismo, passa por uma transição para se tornar parte do gerenciamento de empresas. Segundo os autores, as Relações Públicas guardam a perspectiva única de trazer a visão dos diferentes públicos para a mesa de decisão nas empresas. Essas diferenças enriquecem a visão do gerenciamento cada vez mais. Por isso, podemos afirmar que relações publicas são especializados em chamar a atenção dos líderes 
das organizações com a perspectiva da sociedade e, portanto, sofrem influência das questões culturais presentes no ambiente social e corporativo.

Por ser um elemento essencial na formação da estrutura das organizações, os resultados da pesquisa realizada nos permite afirmar que a cultura influencia diretamente a prática de comunicação e relações públicas nas empresas, impactando os relacionamentos entre pessoas, grupos, organizações e países. O Quadro 9 demonstra de que forma se dá essa relação, de acordo com a pesquisa realizada.

Quadro 9: Relação entre cultura organizacional e as percepções de comunicação nas empresas pesquisadas

\begin{tabular}{|l|l|}
\hline Elementos da Cultura Organizacional & Percepções de Comunicação \\
\hline $\begin{array}{l}\text { Consideram o incentivo à participação, a } \\
\text { confiança e o desenvolvimento dos funcionários }\end{array}$ & $\begin{array}{l}\text { Buscam realizar ações que } \\
\text { correspondem aos modelos de mão } \\
\text { dupla }\end{array}$ \\
\hline $\begin{array}{l}\text { Percebem a empresa como uma "família" e os } \\
\text { colegas repartem suas experiências pessoais }\end{array}$ & $\begin{array}{l}\text { Ações refletem a necessidade de } \\
\text { utilização do modelo assimétrico de } \\
\text { duas mãos, baseado na persuasão }\end{array}$ \\
\hline $\begin{array}{l}\text { Preocupação em seguir regras pré-definidas e e } \\
\text { realizar tarefas, em estruturas mais rígidas e e } \\
\text { centralizadas }\end{array}$ & $\begin{array}{l}\text { Açóes priorizam fluxo de } \\
\text { comunicação de mão única }\end{array}$ \\
\hline $\begin{array}{l}\text { Postura de espectador } \\
\text { Tendência a evitar conflitos }\end{array}$ & $\begin{array}{l}\text { Oportunidade estratégica: ações } \\
\text { que reforcem as mensagens da } \\
\text { empresa e minimizem eventuais } \\
\text { efeitos negativos }\end{array}$ \\
\hline
\end{tabular}

Fonte: a autora, com base nos resultados da pesquisa, apresentados no Capítulo 4.

Mais do que uma apresentação de resultados, o Quadro 9 serve para reforçar que $87 \%$ dos profissionais consultados disse que a cultura do país e a cultura da organização têm influência sobre as ações e processos de comunicação na empresa. E, portanto, conhecer bem as diferenças e características culturais corporativas é determinante para quem tem o desafio de atuar como comunicador empresarial, em um mundo cada vez mais competitivo. 
3) Em que extensão os elementos da cultura organizacional colaboram ou impedem a realização de um processo estratégico de comunicação?

Pela pesquisa realizada não foi possível medir a extensão do impacto da cultura organizacional sobre ações de comunicação mais ou menos estratégicas. Detectamos que, ao contrário do que poderia dizer o senso comum, as empresas brasileiras pesquisadas têm um perfil de cultura do tipo Clã, porém praticam atividades de comunicação com nível alto de excelência, priorizando relações simétricas e transparentes.

Talvez seja possível que algumas empresas, para elevar seu grau de competitividade e reputação, consigam modelar sua cultura organizacional de forma mais igualitária, apesar da força natural da cultura do país. Para citar um exemplo, a Natura, empresa de cosméticos e beleza, foi pioneira nessa alternativa, entre organizações brasileiras. É uma empresa que sabe como utilizar, de forma estratégica, as mensagens de comunicação e marketing para parecer descolada do ambiente cultural em que está inserida.

Para que isso seja possível em outras empresas, é preciso que o poder decisório em seus vários níveis seja desenvolvido e exercitado. É preciso implantar mecanismos que favoreçam a mudança cultural ou mesmo a forma de operacionalizar os valores, porque o processo inercial leva a pessoa a agir em conformidade com a estrutura de poder mais centralizado vigente (Tanure, 2005).

E, no caso do Brasil, os traços e características culturais que estão presentes também no ambiente corporativo acabam por determinar comportamentos quase que involuntários. Mesmo sem querer, brasileiros revelam pensamentos e sentimento verbalmente e não verbalmente; são acalorados, não se retraem ao toque físico, têm gestos e fortes expressões, suas falas são fluentes e dramáticas. Vivemos em uma sociedade alegre, harmônica mesmo na pobreza; criativa, mas com baixo nível de crítica. Com ou sem estratégia, tudo isso é comunicação. Tanto que a forma como lidamos com estes aparentes paradoxos deixa os observadores externos admirados com nosso jeito de ser. 


\section{CONSIDERAÇÕES FINAIS}

Ao finalizar esta dissertação podemos afirmar que todo rigor metodológico e esforço de execução da pesquisa foram direcionados para conhecer e compreender a relação entre cultura e comunicação. O objetivo inicial deste trabalho era verificar se os traços da cultura organizacional interferem na prática da comunicação nas empresas brasileiras; e ele foi cumprido.

Ao longo do estudo percebemos que por ser um elemento essencial na formação da estrutura das organizações, a cultura influencia diretamente a prática de comunicação nas empresas, impactando também os relacionamentos entre pessoas, grupos e países. Para se aproximar contextualizar o objeto de estudo, buscou-se identificar quais são os traços da cultura organizacional mais marcantes no âmbito corporativo brasileiro, aplicando uma sondagem com 50 empresas que atuam no país.

O resultado desta sondagem demonstrou que a maior parte das empresas brasileiras pesquisadas tem um perfil cultural do tipo Clã (Cameron e Quinn, 2006) e exercem atividades de comunicação com alto nível de excelência, priorizando ações simétricas e transparentes (Grunig e Hunt, 1884). Empresas do tipo Clã apresentam uma cultura de preservação, privilegiam relações harmoniosas, que tem como características o paternalismo e a lealdade entre líderes e liderados.

Além disso, estudos conduzidos por Tanure (2005) mostraram que organizações com o perfil de cultura Clã apresentam certa ambiguidade nas regras e normas, privilegiam vínculos, têm a tendência a tomar posturas políticas e a depender de redes de amizades e camaradagem para obterem sucesso. Essas culturas, que combinam alto índice de concentração de poder com baixo individualismo, são típicas dos países com maior distância hierárquica, como é o caso do Brasil.

A pesquisa realizada apontou também que $87 \%$ dos profissionais consultados acreditam que a cultura do país influi na cultura da organização, que por sua vez, têm influência sobre as ações e processos de comunicação na empresa. O processo de comunicação estudado apresentou algumas características peculiares e a sondagem com profissionais da área de comunicação demonstrou que, cada vez mais, a atividade e a função de comunicação organizacional e Relações Públicas vêm se estabelecendo como um dos elementos estratégicos para 
entendimento das necessidades dos diversos públicos, incluindo funcionários, mercado e clientes. Não se trata apenas de um fluxo simples de comunicação entre emissor e receptor. A comunicação praticada nas empresas pesquisadas vai além e busca princípios de excelência.

A pesquisa entre as empresas brasileiras consultadas demonstrou que os profissionais realizam uma comunicação que parece equilibrar o impacto das características culturais sobre as dificuldades do dia a dia das organizações, amenizando conflitos, mediando relações entre líder e subordinado, oferecendo sentido para a execução de tarefas. Dessa forma, concluímos que existem traços culturais e comportamentais comuns que determinam e influenciam a prática de comunicação nas empresas, tais como: envolvimento da liderança, distância hierárquica e centralização do poder.

No caso das empresas brasileiras pesquisadas percebe-se que houve uma adequação na estratégia de comunicação para se atender às necessidades do ambiente cultural e do tipo de cultura predominante - a cultura Clã. Por outro lado, em função de restrições metodológicas, não foi possível determinar em que extensão e de que maneira as empresas efetivamente adequaram suas estratégias de comunicação para conseguirem adaptar-se aos ambientes culturais em que estão inseridas.

O que fica claro é que a comunicação estratégica passou a ser relevante para todas organizações que estão expandindo para novos mercados e culturas, pois questões de contexto cultural envolvem desde adequação de estratégias para adaptar-se a novas realidades ou ambientes diversos, até situações cotidianas que forçam as empresas a lidar com influências da cultura nas organizações. Nesse contexto intercultural global, torna-se cada vez mais difícil gerar resultados, se for mantido o modelo de gestão autoritária, que evidencia a inexistência do diálogo ou mesmo a distância entre discurso e prática. O cenário empresarial atual exige uma postura que privilegie a comunicação, respeitando as diferenças culturais.

A pesquisa mostrou ainda que, de modo geral, as empresas avaliadas parecem priorizar relacionamentos de mão dupla, realizar atividades simétricas de comunicação e relações públicas excelentes (Grunig, 1992). Considerando que a maioria das empresas consultadas é de médio ou grande porte, o resultado da sondagem nos permite inferir que a comunicação nas empresas estudadas prioriza a participação dos executivos da área de comunicação nos processos de decisão, já que este é um dos dez princípios que compõe a Teoria da Excelência de Grunig (1992). 
Do ponto de vista da comunicação, os resultados demonstraram que as empresas buscam práticas estratégicas, alinhadas com os princípios de excelência, quase que na tentativa de minimizar dificuldades que a cultura do tipo Clã impõem à gestão empresarial. É possível inferir que nas empresas com estruturas hierarquizadas, o profissional de relações públicas encontra ambiente mais propício para aplicar ferramentas de comunicação participativa, pois a organização necessita desse tipo de informação do público para manter-se ativa.

Quando o assunto é cultura e comunicação não existe receita pronta. O contexto e o ambiente são sempre fatores relevantes para a comunicação organizacional. É fato que entre as empresas pesquisadas ocorre a combinação de táticas de comunicação assimétricas e simétricas. E esse comportamento demonstra que o processo de comunicação ou as estratégias aplicadas pela empresa não são estáticas ou mandatórias, não são paradigmas em que as empresas simplesmente se encaixam ou não se encaixam. Ao contrário, a empresa pode adotar uma estratégia de comunicação em determinado contexto e em outra situação utilizar uma estratégia diferente, conforme sua necessidade. Ou seja, modelos e formas de se fazer a comunicação coexistem.

\section{Restrições da pesquisa e sugestões para estudos futuros}

Encontramos algumas restrições que merecem ser destacadas e também algumas sugestões que compartilhamos para eventuais estudos futuros sobre o mesmo tema. Uma das dificuldades encontradas foi a disponibilidade dos profissionais do mercado para responder a pesquisas acadêmicas para realização deste trabalho. $\mathrm{O}$ distanciamento entre academia e mercado no Brasil, de certa forma, não motiva os profissionais para colaborar com pesquisas acadêmicas. Avaliamos ainda que essa dificuldade em obter respostas do mercado possa ter origem no aumento do desemprego em função da crise político-econômica que o pais enfrenta. Apenas de 2014 para 2015, período de coleta das respostas, o número de desempregados aumentou $40 \%$ e isso pode ter atingido diretamente as estruturas de comunicação das empresas, prejudicando o contato com os profissionais, que possam não fazer mais parte da empresa ou terem restrição de tempo para responder à pesquisa, em função de cortes na equipe.

Outra restrição importante com relação ao resultado obtido foi o perfil dos respondentes selecionados. Ao limitarmos as respostas apenas ao profissional de Comunicação, o resultado da pesquisa foi construído com a voz da comunicação pela comunicação. Ou seja, existe o 
risco de profissionais do setor se auto-avaliarem com viés positivo, em questões específicas sobre comunicação e esse possa ter sido um limitador metodológico para a pesquisa realizada. Além disso, ao concluir o trabalho, pareceu importante que os respondentes apresentassem um perfil variado, com representantes de outras áreas e não apenas da comunicação. Ter respondente único, no contexto de um estudo sobre cultura, também pode ter sido um limitador metodológico.

Por fim, recomenda-se que essa temática seja aprofundada em estudos futuros buscando trazer outros resultados tanto para pesquisas focadas no Brasil, assim como na América Latina. Uma possibilidade é ampliar a pesquisa para outros países da região latino-americana e comparar os resultados em um estudo intercultural. Além disso, a aplicação da pesquisa em um número maior de empresas poderá contribuir na identificação do perfil cultural das organizações e gerar maior representatividade e possibilidade de generalização dos resultados encontrados.

Há ainda a opção de se realizar nova pesquisa combinando métodos quantitativos a qualitativos com entrevistas em profundidade, com o objetivo de esclarecer pontos que possam ter gerado mais dúvidas. Além disso, segmentar a análise por setor da economia, por região e/ou país, ou por porte da empresa, sempre traçando um paralelo com as interferências culturais sobre esses aspectos também parece ser uma boa sugestão. 


\section{REFERÊNCIAS}

ÁLVAREZ, Assumpta A. Competência intercultural: competência clave en lãs organizaciones actuales. In: AYALA, Encarnación S. Ayala (coord.) Vivir entre culturas: una nueva sociedad.. p.151-175. Madrid: Editorial La Muralla. S.A, 2009.

ALLEN, Matthew R.; DOZIER, David M. When Cultures Collide: Theoretical Issus in Global Public Relations. In: SRIRAMSH, K. ; VERCIC, D. (Orgs.) Culture and Public Relations - Links and Implication. p. 183-201. New York: Routledge, 2012.

ANTHONY, P. Managing culture. Buckingham: Open University Press, 1994.

ANDERBERG, Michael R. Cluster analysis for applications. New York: Academic Press, 1973.

BARBOSA, Lívia; VELOSO, Letícia. A cultura do outro: interculturalidade e dialogia nas empresas. In: Cultura e diferença nas organizações. p.161-213. São Paulo: Atlas, 2009

BARBER, J.P. e DARDER, F.L. Direccíon de Empresas Internacionales. Madrid, Pearson Prentice Hall, 2004.

BARDHAN Nilanjana; WEAVER, Kay C. (orgs). Public Relations in Global Cultural Contexts: Multi-Paradigmatic Perspectives. New York: Routledge, 2011.

BARBETTA, Pedro Alberto. Estatística Aplicada às Ciências Sociais, Cap. 3. Ed. UFSC, 5a Edição, Florianópolis, 2002

BARRETO, A.; ROCHA, A. A expansão das fronteiras: brasileiros no exterior. In: As novas fronteiras: a multinacionalização das empresas brasileiras. $1^{\mathrm{a}}$ ed. Rio de Janeiro, Mauad, 2003.

Por que as empresas brasileiras não se internacionalizam? In:

ROCHA, A. (Ed.) As novas fronteiras: a multinacionalização das empresas brasileiras. $1^{\mathrm{a}}$ ed. Rio de Janeiro: Mauad, 2003.

BARRETO, Leilianne M. T da S.; KISHORE, Angeli; REIS, Germano Glufke et Al.

Cultura Organizacional e Liderança: uma relação possível? R. ADM. V.48 N1 - p.34-52,

São Paulo, 2013.

BARROS, Betânia T. de, PRATES, Marco A. S. O estilo brasileiro de administrar. São Paulo: Atlas, 1996. 
BENEDICT, Ruth. O crisântemo e a espada: padrões da cultura japonesa. São Paulo: Perspectiva, 1972.

BENNETT, Milton J. 2011. Entrevista para a Revista Época, disponível em: http://revistaepoca.globo.com/Revista/Epoca/0,EMI250960-15228,00INTERCULTURALIDADE+VOCE+SABE+O+QUE+E.html

BLOOM, N. VAN REENEN, J. Why do Management practices differ across firms and countries?, in Journal of Economic Perspectives - vol.24

CAMERON, Kim S.; QUINN Robert E. Diagnosing and changing organizational culture. Revised Edition, Jossey-Bass, California, 2006.

CARNEIRO, Jorge; ROCHA, Angela; SILVA, Jorge Ferreira. A critical analysis of measurement models of export performance. Brazilian Administration Review, Curitiba, v.4, n.2, p.1-19, May/Aug. 2007.

CALDAS, Miguel P.; ALCADIPANI, Rafael. Americanizing Brazilian management. Critical perspectives on international business. V.8; n.1; p.37-55; 2012.

CASANOVA, Loudes. Global Latinas: Latin America's Emerging Multinationals. London: Palgrave, 2009.

Las multinacionales latinoamericanas en los albores de una gran oportunidad. São Paulo: RAE. V.50. n.3, p.439-445, 2010.

CASTELLS, Manuel. A Sociedade em rede. Volume I. São Paulo: Paz e Terra, 2000.

CHU, Rebeca A. ; WOOD JR., Thomaz. Cultura Organizacional brasileira pósglobalização: global ou local?. Rio de Janeiro: RAP. v.45; n.5; p.969-991, 2008.

COX, Taylor. J. Cultural Diversity in Organizations: theory, research \& practice. San Francisco, Berret-Kohler, 1994.

DONI, Marcelo Viana. Análise de Cluster: métodos hierárquicos e de particionamento. Universidade Presbiteriana Mackenzie. São Paulo, 2004.

CUTLIP, Scott M.; CENTER, Allen H.; BROOM, Glen M. Effective public relations. 9a ed. London: Prentice Hall, 2006.

DUNNING, J. H., HOESEL, R. V., \& NARULA, R. Third world multinationals revisited: new developments and theoretical implications, in: Globalization, Trade and Foreign Direct Investment. Oxford: Pergaman, 1997. 
DUNNING, J.H. Multinational Enterprises and the Global Economy. Wokingham: Addison-Wesley, 1993.

DUPAS, G. Atores e poderes na nova ordem global. SP: Unesp, 2005.

FELDMAN, Paulo Roberto. A influência da cultura na gestão das empresas latinoamericanas. Estudos Avançados, (USP. Impresso), v. 24, p. 321-334, 2010.

FERRARI, M. Aparecida. A influência dos valores organizacionais na determinação da prática e do papel dos profissionais de Relações Públicas: estudo comparativo entre organizações do Brasil e do Chile. Tese de Doutorado em Ciências da Comunicação. São Paulo: ECA-USP, 2000.

. Contexto global e latino-americano da comunicação e relações públicas. In: Relações Públicas - teoria, contexto e relacionamentos. $2^{\mathrm{a}}$ ed. p. 131-246. São Caetano do Sul: Difusão, 2011.

Significados, Possibilidades e impasses da comunicação

intercultural. Revista Organicom: Interculturallidade e Organizações. Ano 11. N. 21, p. 1117, São Paulo, 2014. Recurso digital.

Comunicação intercultural, perspectivas, dilemas e desafios. In:

Comunicação, Interculturalidade e Organizações: Faces e dimensões da contemporaneidade. Porto Alegre: EdiPUCRS, 2016. Recurso digital

FINURAS, Paulo. Gestão Intercultural. 2a edição, Lisboa: Silabo, 2007.

FLEURY, A. e FLEURY, M. T. L. (Orgs.). Internacionalização e os países emergentes. São Paulo: Atlas, 2007.

Multinacionais brasileiras: competências para a

internacionalização. São Paulo: FGV Editora, 2012.

Fleury, A. Fleury, MT., Ramamurti, R., Williamson, P. The competitive advantage of emerging market multinationals. New York: Cambrige, 2013.

FREITAS, M. Ester. Cultura Organizacional: evolução e crítica. São Paulo: Thomson, 2007.

Paulo: Thomson, 2008.

O Imperativo Intercultural na vida e na gestão contemporânea. São Cultura Organizacional: Formação, Tipologias e Impacto. São

Paulo: Makron Books do Brasil Editora Ltda, 1991. 
GANESH, Shiv. Da Inteligência à integibilidade cultural: tecnologia digital, ação coletiva e comunicação nos nossos dias. In: Comunicação, Interculturalidade e Organizações: Faces e dimensões da contemporaneidade. Porto Alegre: EdiPUCRS, 2016. Recurso digital.

GRUNIG, James E., FERRARI, Maria A. e FRANÇA, Fabio. Relações Públicas: teoria, contexto e relacionamentos. $2^{\mathrm{a}}$ ed., São Caetano do Sul: Difusão, 2011.

GRUNIG, James E.; HUNT, Todd T. Managing public relations. New York: Holt, Rinehart and Winston, 1984.

GRUNIG, J. E. Excellence in public relations and communication management. Hillsadle, NJ: Lawrence Erlbaum Associates, 1992.

GRUNIG, J. E.; GRUNIG, L.A.; DOZIER, D.M. Excellence in public relations and communication management: A study of communication management in three countries. NJ: Lawrence Erlbaum Associeates, 2002.

GUPTA, A. K., GOVINDARAJAN, V. Cultivating a global mindset. The Academy of Management Executive, v. 16, n. 1, p. 116-126, 2002.

HALL, Edward T. The Silent Language. Garden City, NY: Doubleday, 1959.

HALL, Stuart . Da Diáspora: Identidades e mediações culturais. Belo Horizonte: UFMG: Representações da UNESCO no Brasil, 2003.

.Representation: Cultural Representations And Signifying Practices (Culture, Media And Identities Series) Sage Publications \& Open University 6 Ed. London, 2003

HALKIDI, Maria; BATISTAKIS, Yannis; VAZIRGIANNIS, Michalis. On clustering validation techniques. Journal of Intelligent Information Systems, v. 17, n. 2-3, p. 107-145, Dec. 2001.

HICKSON, David J.; PUGH, Derek S. Management Worldwide: The impact of societal culture on organizations around the globe. Penguin Books: England, 1995.

HILAL, Adriana V.G. de. Dimensões e clusters de cultura organizacional. Rio de Janeiro: Mauad, 2003.

HOFSTEDE, Geert. Culturas e organizações: Compreender a nossa programação mental. Lisboa: Edições Sílabo, 1997.

HOFSTEDE, G. Culture's consequences: international differences in work-related values. Beverly Hills: Sage, 1980.

Riding the waves of culture. McGraw-Hill: London, 1994. 
. Culture's and organizations: software of the mind. McGraw-Hill: USA, 1997.

. Culture's Consequences: Comparing Values, Behaviors, Institutions and Organizations Across Nations. Thousand Oaks CA: Sage Publications, 2001

https://www.ibpt.org.br/noticia/372/Censo-das-Empresas-Brasileiras-2012

http://www.trabajo.gob.ar/left/estadisticas/oede/estadisticas_nacionales.asp

http://www.sii.cl/estadisticas/empresas.htm

http://www.sofofa.cl/sofofa/index.aspx?channel=4301

http://www.empresario.com.co/recursos/page_flip/CCB/2012/estadisticas_empresas_bogota_ 59municipios/\#/2/zoomed

http://www.americaeconomia.com/economia-mercados/finanzas/mas-del-99-de-las-empresasdel-peru-son-pequenas-y-medianas

http://espanol.enterprisesurveys.org

http://datos.bancomundial.org/indicador/IC.BUS.NREG

http://www.inei.gob.pe/estadisticas/censos/

http://censos.inei.gob.pe/cenec2008/tabulados/\#

http://www.indec.gov.ar

https://www.dane.gov.co/index.php/es/que-es-el-sen

IBARRA, Eduardo C. Ante la colonialidad epistémica, pensamiento de las diferencias desde los márgenes: el caso de los Estudios Organizacionales en América Latina. In: En las lindes de las ciencias sociales. DELGADO, M. C. P. Universidad Autónoma de la Ciudad de México. México: 2008.

JOHANSON, J. VAHALNE, J.A. The internationalization process of the firm. Journal of International Bussiness Studies 8, n.1. p. 23-32, 1997

KENT, Michael L.; TAYLOR, Maureen. Toward a dialogic theory of public relations. In: Public Relations Review 28. New Jersey: Pergamon, 2002.

KHANNA, T.; PALEPU, K. The right way to restructure conglomerates in emerging markets. Harvard Business Review. P. 125 - 134, jun/ago. 1999. 
KUNSCH, Margarida M. K. Planejamento de Relações Públicas na comunicação

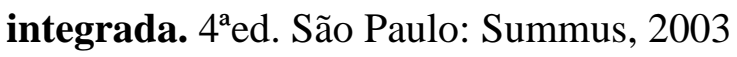

MARCONI, M. A.; LAKATOS, E. M. Fundamentos de Metodologia Científica. São Paulo: Atlas, 2003.

MORGAN, Gareth. Images of organization. Califórnia: Sage, 1997.

MOURA, Claudia Peixoto de.; FERRARI, Maria Aparecida (Orgs). A pesquisa em comunicação organizacional e em relações públicas. Metodologias entre a tradição e a inovação. Porto Alegre: EdiPUCRS, 2014. Recurso eletrônico.

MOURA, Claudia Peixoto de.; FERRARI, Maria Aparecida (Orgs). Comunicação, Interculturalidade e Organizações: Faces e dimensões da contemporaneidade. Porto Alegre: EdiPUCRS, 2016.

LEDERMAN, Daniel; MESSINA, Julián; PIENKNAGURA, Samuel; RIGOLINI, Jamele. El emprendimiento en América Latina: muchas empresas y poca innovación. Estudios del Banco Mundial sobre América Latina y el Caribe - Resumen. Washington: Banco Mundial, 2014.

LEITE, Cristiane Kerches da S., PERES, Úrsula Dias, IGLECIAS, Wagner. Intereses organizados: uma análise comparativa da atuação empresarial na Argentina, no Brasil e no Chile, nas duas últimas décadas. (p. 67 - 90) Costa, Armando Dalla (Orgs.) ET. All. IN: Desenvolvimento e crise na America Latina. Estado, empresas e sociedade. Curitiba, Editora CRV., 2012

OGLIASTRI, E (Org.). Cultura y liderazgo organizacional em 10 países de America Latina: el estudio Globe. Bogotá: Revista Latinoamericana de Administración, no 22, p.2957, 1999.

PAGÉS, C. The age of productivity: transforming economies from the bottom up. New York: Palgrave, 2010.

PORTER, M. Vantagem competitiva das nações. Rio de Janeiro: Elsevier, 1989

RAMAMURTI, R., SINGH, Jitendra V. Emerging Multinationals in Emerging Markets. New York: Cambridge University Press, 2009

REIS, Germano G. Global Mindset e fatores culturais: influências nas competências de subsidiárias brasileiras no exterior. Pesquisa Multinível. Tese de Doutorado em Ciências da Administração. São Paulo: FEA-USP, 2012.

REZENDE, Sérgio F.; VERSIANI, Ângela. Em direção a uma tipologia de processos de internacionalização. São Paulo: RAE. V.50. n.1, p.24-36, 2010. 
RODRIGO ALSINA, Miquel: La Comunicación intercultural, Anthropos Editorial, Barcelona, 1999.

SACKAMNN, Sonja. Cultural knowledge in organizations: exploring the colletive mind. London: Sage, 1991

SCHALL, Maryan. A Communication-rules approach to Organization Culture. Administrative Science Quarterly, vol.28. Dez. 1983.

SCHARMA, Ruchir. Breackout Nations: in pursuit of the next economic miracles. New York: Norton, 2012.

SCHEIN, Edgar H. How Culture Forms, Develops, And Changes. In: KILMANN, R. et all. Gaining Control of the Corporate Culture. São Francisco: Jossey-Bass, 1985.

Press, 1987. The art of managing human resources. New York: Oxford University . Organizational Culture and Leadership. 2nd Edition. San Francisco: Jossey-Bass, 1992.

Cultura Organizacional e Liderança. São Paulo: Atlas, 2009.

The corporate culture survival guide. San Francisco: Jossey-Bass, 2009.

SELLTIZ, C. et al. Métodos de pesquisa nas relações sociais. São Paulo: EPU, 1975.

SRIRAMESH, K. and VERCIC, D. (Orgs.) Culture and Public Relations. Links and Implications. Routledge, New York, 2012.

SRIRAMESH, K. and VERCIC, D. (Orgs.) The Global Public Relations Handbook. Mawah, New Jersey: Lawrence Erlbaum, 2003.

STHOL, C. Globalizing organizational communication. In: F.M. Jablin \& L. L. Putnam (eds.) The new handbook of organizational: advances in theory, research and methods, 2001.

TANURE, Betânia. Gestão à Brasileira. 2a edição. São Paulo, Atlas, 2005.

TANURE, B., Evans, P., \& Pucik, A gestão de pessoas no Brasil: virtudes e pecados capitais (pp. 83-111). Rio de Janeiro: Elsevier, 2007

TONI, Rodrigo S. In: A Pesquisa em Comunicação Organizacional e em Relações Públicas: metodologias entre a tradição e a inovação. iBooks (pg. 320 - 344) 


\section{ANEXOS}

Anexo A: Questionário da pesquisa

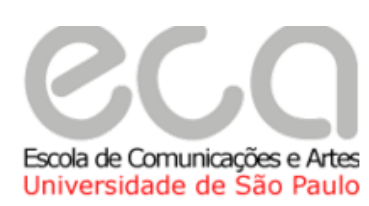

Comunicação e Cultura

da Universidade de São Paulo (ECA/USP).

O objetivo é investigar aspectos sobre a cultura de empresas na América Latina. Suas respostas serão muito importantes para identificarmos quais são as caracteristicas/traços culturais mais comuns nos paises da região e de que forma a cultura influencia a prática de comunicação nas organizações.

A pesquisa está direcionada ao responsável pela área de comunicação das empresas, porque acreditamos que este é o executivo que mais pode colaborar com esse estudo, uma vez que é capaz de avaliar a práticas culturais e comunicacionais da organização onde trabalha. Você não precisará se identificar e poderá fazer isso apenas se desejar. As respostas também não serão identificadas e/ou divulgadas como representativas da expressão da opinião da empresa.

O questionário está dividido em três partes: perguntas sobre cultura organizacional, perguntas sobre o processo de comunicação e dados do entrevistado. São cerca de 5 páginas, com duração máxima estimada de 15 minutos para finalizar.

Em nome da ECA/USP, a equipe de pesquisadores deste estudo deseja expressar os agradecimentos por seu interesse e valorização a esse projeto. Obrigado por sua participação e disponibilidade em responder a todas as questões. 
Questões sobre Cultura Organizacional

$22 \%$

As afirmações a seguir referem-se às suas percepções e seu comportamento no seu ambiente de trabalho

1. Leia cada afirmação cuidadosamente e avalie se já se comportou assim em relação ao seu trabalho ou se já

percebeu esse comportamento de forma geral na empresa. Classifique cada frase de acordo com a escala de 1 a 5 , sendo 1 se você discorda totalmente com a afirmação, e 5 se você concorda totalmente.

1. Discordo

totalmente

2. Discordo

3. Indiferente

4. Concordo

5. Concordo

1. A minha empresa

como se fosse uma

família. Meus colegas de

trabalho repartem suas

experiências pessoas $\mathrm{e}$ as

de trabalho.

2. A minha empresa é um

lugar que está

constantemente mudando.

As pessoas estão sempre

mudando para melhorar.

3. Na minha empresa, 0

trabalho é voltado para o 
3. Na minha empresa, 0

trabalho é voltado para o

resultado, onde a

preocupação principal é

terminar a tarefa.

4. A minha empresa é um

lugar muito rígido, onde

tudo que faço é controlado

pelo chefe.

5. Os meus superiores

geralmente incentivam

meu trabalho.

6. Os meus superiores

são considerados

dinâmicos. Estão sempre

tentando inovar para

maior sucesso da

empresa.

7 Os meus superiores

estão sempre

preocupados em atingir

metas e conseguir

resultados.

8 Os meus superiores

são exemplo de

organização e eficiência. 
9. A maneira como meu

chefe comanda é

caracterizada por trabalho

de equipe e participação.

10. Amaneira como meu

chefe comanda é

caracterizada por aceitar a

liberdade de cada um e 0

estimulo a fazer coisas na

forma que os

colaboradores acham

melhor.

12. A maneira como meu

chefe comanda é mais

caracterizada por

estabilidade do que por

mudanças rápidas.

13. Na minha opinião, o

que mantém a empresa

unida é a lealdade e a

confiança entre as

pessoas, onde todos

estão comprometidos com

o trabalho 
14. Na minha opinião, o

que mantém a empresa

unida é todos estarem

preocupados com 0

desenvolvimento da

empresa, procurando

sempre fazer coisas

novas.

15. Na minha opinião, o

que mantém a empresa

unida é a preocupação em

atingir metas. Tem a

ambição de ser uma das

melhroes entre as

empresas do setor.

16. Na minha opinião, o

que mantém a empresa

unida é a preocupação em

seguir as regras definidas.

17. A minha empresa

incentiva a participação, a

confiança e o

desenvolvimento dos

colaboradores.

18. A minha empresa

incentiva as pessoas a

enfrentar novos desafios e

experimentar coisas novas

para melhoria da 
19. A minha empresa

incentiva a competição

para aumentar a

produtividade e 0 alcance

de resultados.

20. A minha empresa

procura a estabilidade e 0

funcionamento sem

transtorno.

21. Para a minha

empresa, o sucesso é o

desenvolvimento das

pessoas, o trabalho em

equipe $\mathrm{e} 0$

comprometimento com o

trabalho.

22. Para a empresa, 0

suceso é vender sempre

mais, ou seja, ser o líder

de mercado.

\section{Para a empresa, 0}

sucesso é ter eficiência

cumprir prazos, seguir a

programação sem

problemas e produzir a

baixos custos. 
As afirmações a seguir referem-se às suas atividades na área de comunicação

2. As afirmaçōes a seguir referem-se às suas atividades na área de comunicação. Leia cada afirmação cuidadosamente e avalie se é verdadeira ou falsa, de acordo com sua realidade de trabalho. Marque a opção que melhor se identificar com o seu comportamento. Em caso de dúvida, não assinale nenhuma resposta. Esteja ciente que, ao marcar uma

resposta que não corresponda à realidade da prática de comunicação na sua empresa ou país, você poderá interferir no resultado geral da pesquisa. Por isso, pedimos sua opinião sincera. Lembre-se: você não precisa se identificar se assim desejar.

Verdadeiro

Falso
1. Na sua empresa, as
ações de comunicação,
sejam internas ou
externas, são realizadas
após pesquisas que
trazem indicadores de
mercado.

2. Na sua empresa, a

comunicação praticada

busca equilibrar os

interesses econômico

com os interesses dos

públicos com os quais ela

se comunica, com 0

objetivo de cultivar

manter bons

relacionamentos. 
3. A cultura do seu pais e

a cultura da organização

onde você trabalha têm

influencia sobre

e processos de

comunicação na sua

empresa.

4. Na sua empresa, em

situações específicas,

determinadas ações de

comunicação são

utilizadas com o objetivo

de obter publicidade

favorável para a

organização ou para

algum executivo em

especial.

5. As ações de

comunicação realizadas

pela sua área são fruto de

um trabalho planejado

para atingir objetivos

estratégicos para a

organização.

6. As divulgações externas

realizadas atualmente

pela área de comunicaç̃o

da sua empresa têm como

principal objetivo

7. A sua empresa conta

com canais para ouvir

reclamações e

considerações do público

externo e utiliza esse

feedback para planejar

sua comunicação. 
Questões sobre comunicação

$44 \%$

As questões a seguir se referem às suas atividades na área de comunicação. Marque a opção que melhor se identificar com o seu comportamento.

Em caso de dúvida, não assinale nenhuma resposta. Esteja ciente que, ao marcar uma resposta que não corresponda à

realidade da prática de comunicação na sua empresa ou país, você poderá interferir no resultado geral da pesquisa. Por isso, pedimos sua opinião sincera

Lembre-se: você não precisa se identificar se assim desejar

3. Como executivo de comunicação, vejo que o trabalho que a área de comunicação realiza na empresa produz relacionamentos de:

A) longo prazo (mais de um ano de duração)

B) médio prazo

C) curto prazo (menos de seis meses de duração)

\section{As açöes de comunicação realizadas pelo seu departamento são resultado de:}

A) pesquisas ou sondagens com os públicos afetados

B) planos desenvolvidos com base em demandas internas

C) um plano global aplicado localmente 
4. As açōes de comunicação realizadas pelo seu departamento säo resultado de:

A) pesquisas ou sondagens com os públicos afetados

B) planos desenvolvidos com base em demandas internas

C) um plano global aplicado localmente

5. Considerando a localizaçäo hierárquica da comunicação no organograma da sua empresa, você entende que:

A) Quanto mais próxima da presidência, mais estratégica são as ações da área e melhor a área pode apoiar as realizações da empresa

B) A localização da área não tem relação com a sua relevância estratégica para os negócios da empresa

C) A área não está próxima da presidência, porém acompanha as estratégias da organização e alcança objetivos, assim como outras áreas da empresa

6. Como você resumiria as açöes de comunicaçäo realizadas pela sua empresa hoje:

A) Uma tentativa de proteger a imagem da organização

B) Um processo continuo e permanente para alavancar a reputação positiva da empresa frente à sociedade

c) Uma contribuição para minimizar as vulnerabilidades a que a organização está exposta e, assim, prevenir possiveis crises 
Questões sobre comunicação

As questões a seguir tratam da estrutura de comunicação e do modelo de atuação da empresa. Por favor, escolha a opção que mais se aproxime da sua realidade profissional:

7. Como principal executivo da área de Comunicação, você se reporta a:

$\square$ Presidente do Conselho (ou o mais alto cargo do Conselho da Diretoria)

CEO / Presidente / Diretor Executivo (ou o mais alto cargo na organização)

Diretor de Marketing

Diretor Financeiro

Diretor de Recursos Humanos

Diretor do Jurídico

Diretor de Planejamento Estratégico

Chefe de uma Unidade de Negócio

Outras (especifique) 
8. Como principal executivo da área de Comunicação, você é responsável pelas seguintes áreas (assinale quantos itens forem pertinentes):

Administração de Crises

Comunicação externa / Relações Públicas / Reputação

Comunicação interna

Comunicação junto a Doadores ou Comitê de Arrecadação de Fundos/Patrocínios

Comunicação na web (online e redes sociais)

Marketing/Publicidade/Comercial/Relacionamento com o Consumidor

Pesquisa, Planejamento e/ou Mensuração

Relações com a Comunidade

Relações com o Governo / Assuntos Públicos

Relações com os meios de comunicação / imprensa

Relacionamento com Investidores

Responsabilidade Social Corporativa / Filantropia

Outras (especifique) 
9. O número total aproximado de funcionários na sua empresa é:
Abaixo de 100
Entre 101 e 500
Entre 501 e 1.000
Entre 1.001 e 5.000
Acima de 5.000

10. O número total de pessoas que trabalham na área de comunicaçäo na sua empresa (apenas no seu pais) é de:

o a 5

6 a 10

11 a 20

21 a 30

Acima de 30

11. No seu trabalho, suas responsabilidades incluem a formulação de projetos de comunicaçäo com abrangência:

Internacional ou global

Continental (por ex. América do Norte ou Europa, ou América Central e do Sul)

Nacional

Local ou regional

12. Sua empresa realiza alguma atividade fora do seu pais de origem?

Sim

Não

$$
\text { Ativados pela }
$$

SourveyMonkey

$$
\text { Veja como é tácil criar um questionário. }
$$


13. Caso tenha respondido "sim" à pergunta anterior, onde se realizam as atividades fora do pais de origem?

Em paises vizinhos ou próximos

Na América Latina

Em outro continente

Em mais de um continente

14. Qual é o nível de terceirização das atividades de comunicação nesta empresa?

Entre $100 \%$ e $80 \%$ - todas ou quase todas as atividades são terceirizadas

Entre $70 \%$ e $50 \%$ - a maior parte das atividades são terceirizadas

Entre $40 \%$ e $20 \%$ - poucas atividades são terceirizadas

Não existe terceirização - tudo é realizado internamente

15. Na sua organização, tanto a comunicação interna como a comunicação externa são praticadas em um mesmo departamento/área? 
16. Se você respondeu NÃO à pergunta anterior, quais das seguintes funçóes pertencem a outros departamentos ou

são responsabilidades de outra área que não a de Comunicação (assinale quantos itens forem pertinentes):

$\square$ Administração de Crises

Comunicação externa / Relações Públicas / Reputação

Comunicação interna

Comunicação junto a Doadores ou Comitê de Arrecadação de Fundos/Patrocínios

Comunicação na web (online e redes sociais)

Marketing/Publicidade/Comercia/Relacionamento com Consumidor

Pesquisa, Planejamento e/ou Mensuração

Relacionamento com Investidores

Relações com a Comunidade

Relações com o Governo / Assuntos Públicos

Relações com os meios de comunicação / imprensa

Responsabilidade Social Corporativa / Filantropia

Outro (especifique) 
Identificação

Por gentileza, apenas para fins de registro e arquivamento, forneça as informações a seguir:

\section{Preencha os campos abaixo:}

Seu nível máximo de

instrução (gradução, pós-

graduação, etc.)

Formação profissional

(curso da sua graduação)

Setor da empresa onde

trabalha

Relação entre a empresa

que trabalha e o mercado

(B2B, B2C, etc.)

Sua idade

Gênero (feminino,

masculino)

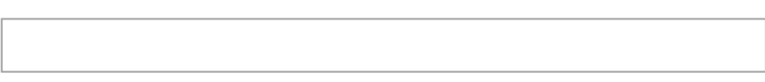

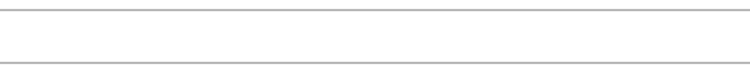



\begin{tabular}{|l|}
\hline \\
\hline
\end{tabular} 
Formação profissional

Setor da empresa onde

trabalha

Relação entre a empresa

que trabalha e o mercado

(B2B, B2C, etc.)

Sua idade

Gênero (feminino

masculino)

Onde trabalha (opcional,

apenas para controle do

número de respostas de

cada empresa)

Cargo/função atual na

empresa

Caso queira ter acesso aos

resultados do estudo, deixe

seu email





Comunicaçäo e Cultura na América Latina

Nossa enorme gratidão!

Em nome da ECA/USP, a equipe de pesquisadores deste estudo sobre a prática da comunicação nas organizações, agradece

sua participação, interesse e valorização de projetos acadêmicos

Muito obrigadol

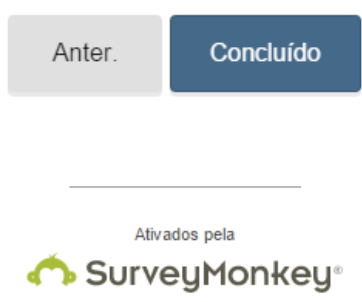




\section{ANEXO B - ANALISE DO ROTEIRO DE PESQUISA}

(PRIMEIRA PARTE)

PERCEPÇÕES SOBRE CULTURA ORGANIZACIONAL

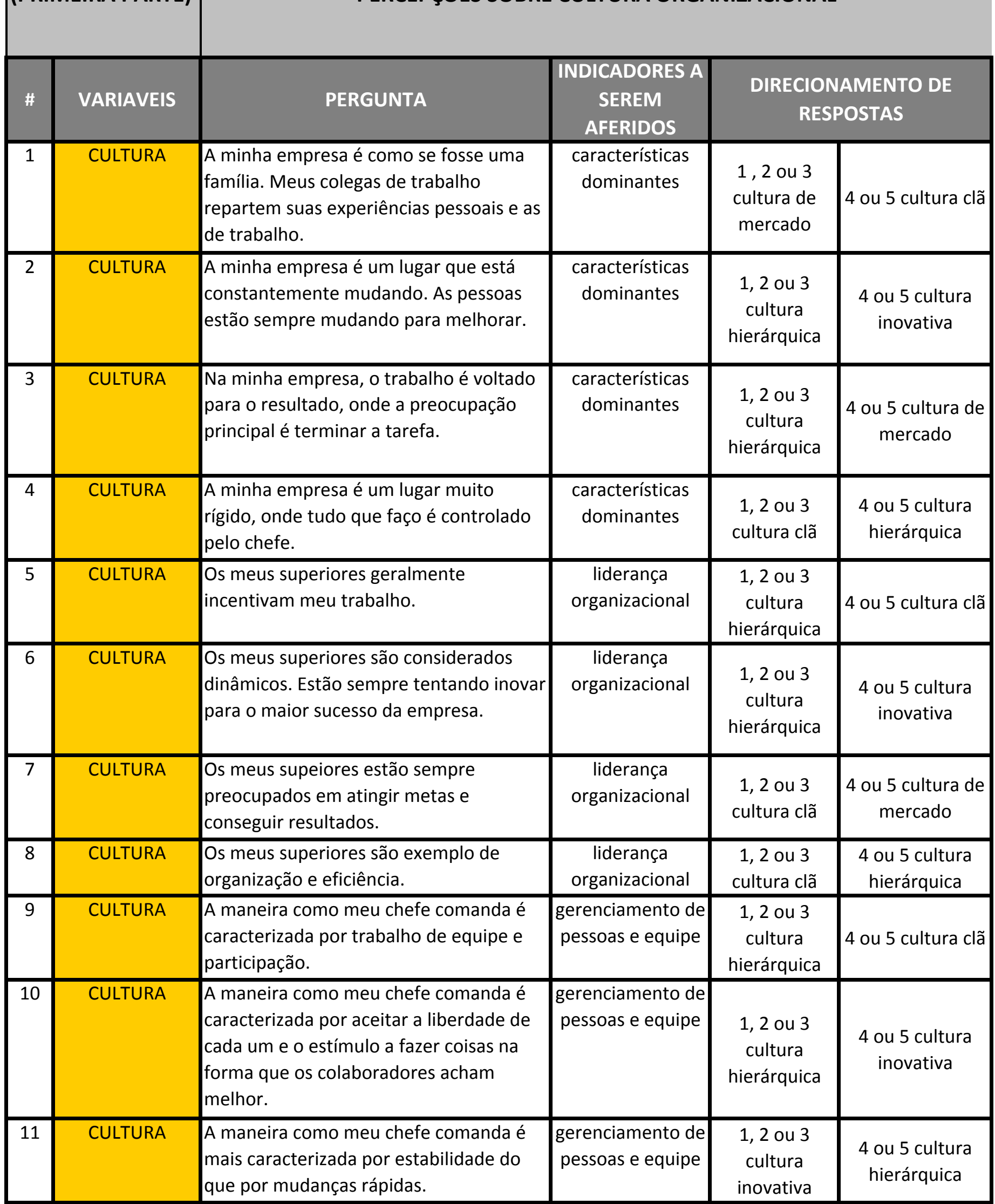




\begin{tabular}{|c|c|c|c|c|c|}
\hline 12 & CULTURA & $\begin{array}{l}\text { A maneira como meu chefe comanda é } \\
\text { centrada em atingir resultados e ganhar } \\
\text { dos concorrentes. }\end{array}$ & $\begin{array}{l}\text { gerenciamento de } \\
\text { pessoas e equipe }\end{array}$ & $\begin{array}{l}1,2 \text { ou } 3 \\
\text { cultura clã }\end{array}$ & $\begin{array}{l}4 \text { ou } 5 \text { cultura de } \\
\text { mercado }\end{array}$ \\
\hline 13 & CULTURA & $\begin{array}{l}\text { Na minha opinião, o que mantém a } \\
\text { empresa unida é a lealdade e a confiança } \\
\text { entre as pessoas, onde todos estão } \\
\text { comprometidos com o trabalho. }\end{array}$ & $\begin{array}{c}\text { união } \\
\text { organizacional }\end{array}$ & $\begin{array}{l}1,2 \text { ou } 3 \\
\text { cultura de } \\
\text { mercado }\end{array}$ & 4 ou 5 cultura clã \\
\hline 14 & CULTURA & $\begin{array}{l}\text { Na minha opinião, o que mantém a } \\
\text { empresa unida é todos estarem } \\
\text { preocupados com o desenvolvimento da } \\
\text { empresa, procurando sempre fazer coisas } \\
\text { novas. }\end{array}$ & $\begin{array}{c}\text { união } \\
\text { organizacional }\end{array}$ & $\begin{array}{l}\text { 1, } 2 \text { ou } 3 \\
\text { cultura } \\
\text { hierárquica }\end{array}$ & $\begin{array}{l}4 \text { ou } 5 \text { cultura } \\
\text { inovativa }\end{array}$ \\
\hline 15 & CULTURA & $\begin{array}{l}\text { Na minha opinião, o que mantém a } \\
\text { empresa unida é a preocupação em } \\
\text { atingir metas. Tem a ambição de ser uma } \\
\text { das melhores entre as empresas do setor }\end{array}$ & $\begin{array}{c}\text { união } \\
\text { organizacional }\end{array}$ & $\begin{array}{l}1,2 \text { ou } 3 \\
\text { cultura clã }\end{array}$ & $\begin{array}{l}4 \text { ou } 5 \text { cultura de } \\
\text { mercado }\end{array}$ \\
\hline 16 & CULTURA & $\begin{array}{l}\text { Na minha opinião, o que mantém a } \\
\text { empresa unida é a preocupação em } \\
\text { seguir as regras definidas. }\end{array}$ & $\begin{array}{c}\text { união } \\
\text { organizacional }\end{array}$ & $\begin{array}{l}1,2 \text { ou } 3 \\
\text { cultura } \\
\text { inovativa }\end{array}$ & $\begin{array}{l}4 \text { ou } 5 \text { cultura } \\
\text { hierárquica }\end{array}$ \\
\hline 17 & CULTURA & $\begin{array}{l}\text { A minha empresa incentiva a } \\
\text { participação, a confiança e o } \\
\text { desenvolvimento dos colaboradores }\end{array}$ & ênfase estratégica & $\begin{array}{c}1,2 \text { ou } 3 \\
\text { cultura de } \\
\text { mercado }\end{array}$ & 4 ou 5 cultura clã \\
\hline 18 & CULTURA & $\begin{array}{l}\text { A minha empresa incentiva a competição } \\
\text { para aumentar a produtividade e o } \\
\text { alcance de resultados }\end{array}$ & ênfase estratégica & $\begin{array}{l}1,2 \text { ou } 3 \\
\text { cultura } \\
\text { inovativa }\end{array}$ & $\begin{array}{l}4 \text { ou } 5 \text { cultura de } \\
\text { mercado }\end{array}$ \\
\hline 19 & CULTURA & $\begin{array}{l}\text { A minha empresa incentiva as pessoas e } \\
\text { enfrentar novos desafios e experimentar } \\
\text { coisas novas para melhoria da empresa }\end{array}$ & ênfase estratégica & $\begin{array}{l}\text { 1, } 2 \text { ou } 3 \\
\text { cultura } \\
\text { hierárquica }\end{array}$ & $\begin{array}{l}4 \text { ou } 5 \text { cultura } \\
\text { inovativa }\end{array}$ \\
\hline 20 & CULTURA & $\begin{array}{l}\text { A minha empresa procura estabilidade e } \\
\text { o funcionamento sem transtorno. }\end{array}$ & ênfase estratégica & $\begin{array}{l}1,2 \text { ou } 3 \\
\text { cultura } \\
\text { inovativa }\end{array}$ & $\begin{array}{l}4 \text { ou } 5 \text { cultura } \\
\text { hierárquica }\end{array}$ \\
\hline 21 & CULTURA & $\begin{array}{l}\text { Para a minha empresa, o sucesso é } \\
\text { desenvolvimento das pessoas, do } \\
\text { trabalho em equipe e do } \\
\text { comprometimento com o o trabalho }\end{array}$ & $\begin{array}{l}\text { critérios de } \\
\text { sucesso }\end{array}$ & $\begin{array}{l}1,2 \text { ou } 3 \\
\text { cultura de } \\
\text { mercado }\end{array}$ & 4 ou 5 cultura clã \\
\hline 22 & CULTURA & $\begin{array}{l}\text { Para a empresa, o sucesso é vender } \\
\text { sempre mais, ou seja, ser o líder de } \\
\text { mercado. }\end{array}$ & $\begin{array}{l}\text { critérios de } \\
\text { sucesso }\end{array}$ & $\begin{array}{c}1,2 \text { ou } 3 \\
\text { cultura } \\
\text { hierárquica }\end{array}$ & $\begin{array}{l}4 \text { ou } 5 \text { cultura de } \\
\text { mercado }\end{array}$ \\
\hline 23 & CULTURA & $\begin{array}{l}\text { Para a empresa, o sucesso é ter o melhor } \\
\text { produto do mercado. }\end{array}$ & $\begin{array}{l}\text { critérios de } \\
\text { sucesso }\end{array}$ & $\begin{array}{l}1,2 \text { ou } 3 \\
\text { cultura clã }\end{array}$ & $\begin{array}{l}4 \text { ou } 5 \text { cultura de } \\
\text { mercado }\end{array}$ \\
\hline 24 & CULTURA & $\begin{array}{l}\text { Para a empresa, o sucesso é ter } \\
\text { eficiência, cumprir prazos, seguir a } \\
\text { programação sem problemas e produzir } \\
\text { baixos custos }\end{array}$ & $\begin{array}{l}\text { critérios de } \\
\text { sucesso }\end{array}$ & $\begin{array}{l}1,2 \text { ou } 3 \\
\text { cultura } \\
\text { inovativa }\end{array}$ & $\begin{array}{l}4 \text { ou } 5 \text { cultura } \\
\text { hierárquica }\end{array}$ \\
\hline
\end{tabular}




\begin{tabular}{|c|c|c|c|c|c|}
\hline$\#$ & TIPO & PERGUNTA & $\begin{array}{l}\text { INDICADORES A } \\
\text { SEREM }\end{array}$ & \multicolumn{2}{|c|}{ EXPECTATIVA DE RESPOSTA } \\
\hline 1 & COMUNICAÇÃO & $\begin{array}{l}\text { Na sua empresa, as ações de } \\
\text { comunicação, sejam internas ou } \\
\text { externas, são realizadas após pesquisas } \\
\text { que trazem indicadores de mercado. }\end{array}$ & Modelos de RP & $\begin{array}{l}\text { Verdadeiro: } \\
\text { modelo } 3 \text { ou } \\
4 \text {; excelencia } \\
+1\end{array}$ & $\begin{array}{l}\text { Falso: modelo } 1 \\
\text { ou 2; excelencia - } \\
1\end{array}$ \\
\hline 2 & COMUNICAÇÃO & $\begin{array}{l}\text { Na sua empresa, a comunicação } \\
\text { praticada busca equilibrar os interesses } \\
\text { econômicos com os interesses dos } \\
\text { públicos com os quais ela se comunica, } \\
\text { com o objetivo de cultivar e manter bons } \\
\text { relacionamentos. }\end{array}$ & Modelos de RP & $\begin{array}{l}\text { Verdadeiro: } \\
\text { modelo } 3 \text { ou } \\
4 \text {; excelencia } \\
+1\end{array}$ & $\begin{array}{l}\text { Falso: modelo } 1 \\
\text { ou 2; excelencia - } \\
1\end{array}$ \\
\hline 3 & COMUNICAÇÃO & $\begin{array}{l}\text { A cultura do seu país e a cultura da } \\
\text { organização onde você trabalha têm } \\
\text { inflência sobre as ações e processos de } \\
\text { comunicação na sua empresa. }\end{array}$ & $\begin{array}{l}\text { Cultura } \\
\text { organizacional e } \\
\text { comunicação }\end{array}$ & $\begin{array}{l}\text { Verdadeiro: } \\
\text { modelo } 3 \text { ou } \\
4 \text {; excelencia } \\
+1\end{array}$ & $\begin{array}{l}\text { Falso: modelo } 1 \\
\text { ou 2; excelencia - } \\
1\end{array}$ \\
\hline 4 & COMUNICAÇÃO & $\begin{array}{l}\text { Na sua empresa, em situações } \\
\text { específicas, determinadas ações de } \\
\text { comunicação são utilizadas com o } \\
\text { objetivo de obter publicidade favorável } \\
\text { para a organização ou para algum } \\
\text { executivo em especial. }\end{array}$ & Modelos de RP & $\begin{array}{l}\text { Verdadeiro: } \\
\text { modelo } 1 \text { ou } \\
\text { 2; excelencia - } \\
1\end{array}$ & $\begin{array}{c}\text { Falso: modelo } 3 \\
\text { ou 4; excelencia } \\
+1\end{array}$ \\
\hline 5 & COMUNICAÇÃO & $\begin{array}{l}\text { As ações de comunicação realizadas pela } \\
\text { sua área são fruto de um trabalho } \\
\text { planejado para atingir objetivos } \\
\text { estratégicos para a organização. }\end{array}$ & Modelos de RP & $\begin{array}{l}\text { Verdadeiro: } \\
\text { modelo } 3 \text { ou } \\
4 \text {; excelencia } \\
+1\end{array}$ & $\begin{array}{l}\text { Falso: modelo } 1 \\
\text { ou 2; excelencia - } \\
1\end{array}$ \\
\hline 6 & COMUNICAÇÃO & $\begin{array}{l}\text { As divulgações externas realizadas } \\
\text { atualmente pela área de comunicação da } \\
\text { sua empresa têm como principal objetivo } \\
\text { promover a organização. }\end{array}$ & Modelos de RP & $\begin{array}{c}\text { Verdadeiro: } \\
\text { modelo } 1 \text { ou } \\
\text { 2; excelencia - } \\
1\end{array}$ & $\begin{array}{c}\text { Falso: modelo } 3 \\
\text { ou } 4 \text {; excelencia } \\
+1\end{array}$ \\
\hline 7 & COMUNICAÇÃO & $\begin{array}{l}\text { A sua empresa conta com canais para } \\
\text { ouvir reclamações e considerações do } \\
\text { público externo e utiliza esse feedback } \\
\text { para planejar sua comunicação }\end{array}$ & Modelos de RP & $\begin{array}{c}\text { Verdadeiro: } \\
\text { modelo } 3 \text { ou } \\
\text { 4; excelencia } \\
+1\end{array}$ & $\begin{array}{c}\text { Falso: modelo } 1 \\
\text { ou 2; excelencia - } \\
1\end{array}$ \\
\hline
\end{tabular}




\begin{tabular}{|c|c|c|c|c|c|}
\hline 8 & COMUNICAÇÃO & $\begin{array}{l}\text { Como executivo de comunicação, vejo } \\
\text { que o trabalho que a área de } \\
\text { comunicação realiza produz } \\
\text { relacionamentos de... }\end{array}$ & Modelos de RP & $\begin{array}{l}\text { A: modelo } 3 \\
\quad \text { ou } 4 ; \\
\text { excelencia }+1\end{array}$ & $\begin{array}{l}\text { B ou C: modelo } 1 \\
\text { ou 2; excelencia - } \\
1\end{array}$ \\
\hline 9 & COMUNICAÇÃO & $\begin{array}{l}\text { As ações de comunicação realizadas pelo } \\
\text { seu departamento são resultado de... }\end{array}$ & Modelos de RP & $\begin{array}{l}\text { A: modelo } 3 \\
\quad \text { ou } 4 ; \\
\text { excelencia }+1\end{array}$ & $\begin{array}{l}\text { B ou C: modelo } 1 \\
\text { ou 2; excelencia - } \\
1\end{array}$ \\
\hline 10 & COMUNICAÇÃO & $\begin{array}{l}\text { Considerando a localização hierárquica } \\
\text { da comunicação no organograma da sua } \\
\text { empresa, você entende que... }\end{array}$ & $\begin{array}{l}\text { Teoria da } \\
\text { Excelência }\end{array}$ & $\begin{array}{l}\text { A: modelo } 3 \\
\quad \text { ou } 4 ; \\
\text { excelencia }+1\end{array}$ & $\begin{array}{l}\text { B ou C: modelo } 1 \\
\text { ou 2; excelencia - } \\
1\end{array}$ \\
\hline 11 & COMUNICAÇÃO & $\begin{array}{l}\text { Como você resumiria as ações de } \\
\text { comunicação realizadas pela sua } \\
\text { empresa hoje }\end{array}$ & $\begin{array}{l}\text { Teoria da } \\
\text { Excelência }\end{array}$ & $\begin{array}{l}\text { B: modelo } 3 \\
\quad \text { ou } 4 ; \\
\text { excelencia }+1\end{array}$ & $\begin{array}{l}\text { A ou C: modelo } 1 \\
\text { ou 2; excelencia - } \\
1\end{array}$ \\
\hline 12 & COMUNICAÇÃO & $\begin{array}{l}\text { Na sua organização, tanto a comunicação } \\
\text { interna como externa são praticadas em } \\
\text { um mesmo departamento/área? }\end{array}$ & $\begin{array}{l}\text { Teoria da } \\
\text { Excelência }\end{array}$ & $\begin{array}{l}\text { Sim: modelo } 3 \\
\quad \text { ou } 4 ; \\
\text { excelencia }+1\end{array}$ & $\begin{array}{c}\text { Não: modelo } 1 \\
\text { ou 2; excelencia - } \\
1\end{array}$ \\
\hline
\end{tabular}


ANEXO C

Tabela 1: Proporção de cada tipo cultural, segundo Cameron e Quinn

\begin{tabular}{|c|c|c|c|c|c|}
\hline & ID_Respondente & Inovativa & Clã & Hierárquica & Mercado \\
\hline 1 & 3262894152 & 0,333 & 0,364 & 0,643 & 0,300 \\
\hline 2 & 3306325658 & 0,222 & 0,364 & 0,643 & 0,400 \\
\hline 3 & 4030360043 & 0,667 & 0,818 & 0,286 & 0,300 \\
\hline 4 & 4031028530 & 0,667 & 0,636 & 0,357 & 0,400 \\
\hline 5 & 4031284771 & 0,556 & 0,727 & 0,571 & 0,100 \\
\hline 6 & 4044593736 & 0,111 & 0,455 & 0,714 & 0,600 \\
\hline 7 & 4044976811 & 0,444 & 0,364 & 0,571 & 0,600 \\
\hline 8 & 4045284328 & 0,556 & 0,636 & 0,286 & 0,600 \\
\hline 9 & 4120803494 & 0,778 & 0,727 & 0,143 & 0,500 \\
\hline 10 & 4169242034 & 0,444 & 0,636 & 0,429 & 0,500 \\
\hline 11 & 4176635852 & 0,778 & 0,545 & 0,214 & 0,600 \\
\hline 12 & 4180400502 & 0,222 & 0,091 & 0,714 & 0,900 \\
\hline 13 & 4180501293 & 0,444 & 0,455 & 0,571 & 0,500 \\
\hline 14 & 4180661297 & 0,333 & 0,273 & 0,500 & 0,800 \\
\hline 15 & 4180774522 & 0,778 & 0,364 & 0,143 & 0,900 \\
\hline 16 & 4182321236 & 0,556 & 0,182 & 0,429 & 0,900 \\
\hline 17 & 4182464473 & 0,667 & 0,727 & 0,286 & 0,400 \\
\hline 18 & 4183148379 & 0,222 & 0,182 & 0,714 & 0,800 \\
\hline 19 & 4183221044 & 0,444 & 0,727 & 0,286 & 0,600 \\
\hline 20 & 4183243194 & 0,222 & 0,364 & 0,643 & 0,700 \\
\hline 21 & 4183381038 & 0,556 & 0,727 & 0,286 & 0,500 \\
\hline 22 & 4183410560 & 0,222 & 0,182 & 0,786 & 0,700 \\
\hline 23 & 4183567837 & 0,333 & 0,636 & 0,571 & 0,400 \\
\hline 24 & 4183724232 & 0,333 & 0,364 & 0,571 & 0,700 \\
\hline 25 & 4184414970 & 0,222 & 0,545 & 0,500 & 0,700 \\
\hline 26 & 4184760694 & 0,222 & 0,091 & 0,786 & 0,800 \\
\hline 27 & 4189196757 & 0,444 & 0,636 & 0,357 & 0,600 \\
\hline 28 & 4189212793 & 0,444 & 0,818 & 0,357 & 0,400 \\
\hline 29 & 4189451504 & 0,556 & 0,545 & 0,571 & 0,300 \\
\hline 30 & 4189505287 & 0,889 & 0,818 & 0,071 & 0,400 \\
\hline 31 & 4190438222 & 0,222 & 0,455 & 0,643 & 0,600 \\
\hline 32 & 4190443292 & 0,333 & 0,455 & 0,643 & 0,500 \\
\hline 33 & 4190674273 & 0,778 & 0,455 & 0,143 & 0,800 \\
\hline 34 & 4191109741 & 0,444 & 0,182 & 0,429 & 0,900 \\
\hline 35 & 4191161795 & 0,556 & 0,545 & 0,357 & 0,600 \\
\hline 36 & 4192648933 & 0,444 & 0,545 & 0,571 & 0,400 \\
\hline 37 & 4194587579 & 0,111 & 0,455 & 0,857 & 0,400 \\
\hline 38 & 4194810364 & 0,556 & 0,545 & 0,357 & 0,600 \\
\hline 39 & 4196537341 & 0,667 & 0,818 & 0,214 & 0,300 \\
\hline 40 & 4196685921 & 0,667 & 0,636 & 0,429 & 0,300 \\
\hline 41 & 4197295502 & 0,778 & 0,545 & 0,143 & 0,700 \\
\hline
\end{tabular}




\begin{tabular}{llllll}
42 & 4197659089 & 0,556 & 0,545 & 0,571 & 0,300 \\
43 & 4199905389 & 0,333 & 0,818 & 0,500 & 0,300 \\
44 & 4200732502 & 0,444 & 0,455 & 0,571 & 0,500 \\
45 & 4203604117 & 0,444 & 0,455 & 0,643 & 0,400 \\
46 & 4205343276 & 0,778 & 0,727 & 0,214 & 0,400 \\
47 & 4208437850 & 0,667 & 0,636 & 0,429 & 0,300 \\
48 & 4238997297 & 0,889 & 0,455 & 0,214 & 0,600 \\
49 & 4249821341 & 0,556 & 0,727 & 0,357 & 0,400 \\
50 & 4258157138 & 0,556 & 0,545 & 0,286 & 0,600 \\
\hline
\end{tabular}

Fonte: a autora, com base em análise estatística realizada para a pesquisa

Tabela 3: Resumo do agrupamento das 50 empresas pesquisadas

\begin{tabular}{ccccccc}
\hline & ID_Respondente & Inovativa & Clã & Hierárquica & Mercado & Grupo \\
\hline 30 & 4189505287 & 0,889 & $\mathbf{0 , 8 1 8}$ & 0,071 & 0,400 & 1 \\
9 & 4120803494 & 0,778 & $\mathbf{0 , 7 2 7}$ & 0,143 & 0,500 & 1 \\
39 & 4196537341 & 0,667 & $\mathbf{0 , 8 1 8}$ & 0,214 & 0,300 & 1 \\
46 & 4205343276 & 0,778 & $\mathbf{0 , 7 2 7}$ & 0,214 & 0,400 & 1 \\
3 & 4030360043 & 0,667 & $\mathbf{0 , 8 1 8}$ & 0,286 & 0,300 & 1 \\
8 & 4045284328 & 0,556 & $\mathbf{0 , 6 3 6}$ & 0,286 & 0,600 & 1 \\
17 & 4182464473 & 0,667 & $\mathbf{0 , 7 2 7}$ & 0,286 & 0,400 & 1 \\
19 & 4183221044 & 0,444 & $\mathbf{0 , 7 2 7}$ & 0,286 & 0,600 & 1 \\
21 & 4183381038 & 0,556 & $\mathbf{0 , 7 2 7}$ & 0,286 & 0,500 & 1 \\
50 & 4258157138 & 0,556 & $\mathbf{0 , 5 4 5}$ & 0,286 & 0,600 & 1 \\
4 & 4031028530 & 0,667 & $\mathbf{0 , 6 3 6}$ & 0,357 & 0,400 & 1 \\
27 & 4189196757 & 0,444 & $\mathbf{0 , 6 3 6}$ & 0,357 & 0,600 & 1 \\
28 & 4189212793 & 0,444 & $\mathbf{0 , 8 1 8}$ & 0,357 & 0,400 & 1 \\
35 & 4191161795 & 0,556 & $\mathbf{0 , 5 4 5}$ & 0,357 & 0,600 & 1 \\
38 & 4194810364 & 0,556 & $\mathbf{0 , 5 4 5}$ & 0,357 & 0,600 & 1 \\
49 & 4249821341 & 0,556 & $\mathbf{0 , 7 2 7}$ & 0,357 & 0,400 & 1 \\
10 & 4169242034 & 0,444 & $\mathbf{0 , 6 3 6}$ & 0,429 & 0,500 & 1 \\
40 & 4196685921 & 0,667 & $\mathbf{0 , 6 3 6}$ & 0,429 & 0,300 & 1 \\
47 & 4208437850 & 0,667 & $\mathbf{0 , 6 3 6}$ & 0,429 & 0,300 & 1 \\
43 & 4199905389 & 0,333 & $\mathbf{0 , 8 1 8}$ & 0,500 & 0,300 & 1 \\
5 & 4031284771 & 0,556 & $\mathbf{0 , 7 2 7}$ & 0,571 & 0,100 & 1 \\
\hline 15 & 4180774522 & $\mathbf{0 , 7 7 8}$ & 0,364 & 0,143 & 0,900 & 2 \\
33 & 4190674273 & $\mathbf{0 , 7 7 8}$ & 0,455 & 0,143 & 0,800 & 2 \\
41 & 4197295502 & $\mathbf{0 , 7 7 8}$ & 0,545 & 0,143 & 0,700 & 2 \\
11 & 4176635852 & $\mathbf{0 , 7 7 8}$ & 0,545 & 0,214 & 0,600 & 2 \\
48 & 4238997297 & $\mathbf{0 , 8 8 9}$ & 0,455 & 0,214 & 0,600 & 2 \\
\hline 1 & 3262894152 & 0,333 & 0,364 & $\mathbf{0 , 6 4 3}$ & 0,300 & 3 \\
2 & 3306325658 & 0,222 & 0,364 & $\mathbf{0 , 6 4 3}$ & 0,400 & 3 \\
37 & 4194587579 & 0,111 & 0,455 & $\mathbf{0 , 8 5 7}$ & 0,400 & 3 \\
13 & 4180501293 & 0,444 & 0,455 & $\mathbf{0 , 5 7 1}$ & 0,500 & 3 \\
44 & 4200732502 & 0,444 & 0,455 & $\mathbf{0 , 5 7 1}$ & 0,500 & 3 \\
& & & & & & \\
\hline
\end{tabular}




\begin{tabular}{ccccccc}
32 & 4190443292 & 0,333 & 0,455 & $\mathbf{0 , 6 4 3}$ & 0,500 & 3 \\
7 & 4044976811 & 0,444 & 0,364 & $\mathbf{0 , 5 7 1}$ & 0,600 & 3 \\
29 & 4189451504 & 0,556 & 0,545 & $\mathbf{0 , 5 7 1}$ & 0,300 & 3 \\
42 & 4197659089 & 0,556 & 0,545 & $\mathbf{0 , 5 7 1}$ & 0,300 & 3 \\
36 & 4192648933 & 0,444 & 0,545 & $\mathbf{0 , 5 7 1}$ & 0,400 & 3 \\
45 & 4203604117 & 0,444 & 0,455 & $\mathbf{0 , 6 4 3}$ & 0,400 & 3 \\
23 & 4183567837 & 0,333 & 0,636 & $\mathbf{0 , 5 7 1}$ & 0,400 & 3 \\
\hline 20 & 4183243194 & 0,222 & 0,364 & 0,643 & $\mathbf{0 , 7 0 0}$ & 4 \\
24 & 4183724232 & 0,333 & 0,364 & 0,571 & $\mathbf{0 , 7 0 0}$ & 4 \\
14 & 4180661297 & 0,333 & 0,273 & 0,500 & $\mathbf{0 , 8 0 0}$ & 4 \\
6 & 4044593736 & 0,111 & 0,455 & 0,714 & $\mathbf{0 , 6 0 0}$ & 4 \\
31 & 4190438222 & 0,222 & 0,455 & 0,643 & $\mathbf{0 , 6 0 0}$ & 4 \\
25 & 4184414970 & 0,222 & 0,545 & 0,500 & $\mathbf{0 , 7 0 0}$ & 4 \\
16 & 4182321236 & 0,556 & 0,182 & 0,429 & $\mathbf{0 , 9 0 0}$ & 4 \\
34 & 4191109741 & 0,444 & 0,182 & 0,429 & $\mathbf{0 , 9 0 0}$ & 4 \\
18 & 4183148379 & 0,222 & 0,182 & 0,714 & $\mathbf{0 , 8 0 0}$ & 4 \\
26 & 4184760694 & 0,222 & 0,091 & 0,786 & $\mathbf{0 , 8 0 0}$ & 4 \\
22 & 4183410560 & 0,222 & 0,182 & 0,786 & $\mathbf{0 , 7 0 0}$ & 4 \\
12 & 4180400502 & 0,222 & 0,091 & 0,714 & $\mathbf{0 , 9 0 0}$ & 4 \\
\hline
\end{tabular}

Fonte: a autora, com base em análise estatística realizada para a pesquisa

Tabela 4: Número de perguntas respondidas, soma e proporção de cada empresa.

\begin{tabular}{ccccc}
\hline & ID_Respondente & $\begin{array}{c}\text { \# de perguntas } \\
\text { respondidas }\end{array}$ & soma de pontos & Proporção \\
\hline 1 & 3262894152 & 12 & 9 & 0,750 \\
2 & 3306325658 & 12 & 9 & 0,750 \\
3 & 4030360043 & 12 & 9 & 0,750 \\
4 & 4031028530 & 12 & 11 & 0,917 \\
5 & 4031284771 & 7 & 2 & 0,286 \\
6 & 4044593736 & 12 & 7 & 0,583 \\
7 & 4044976811 & 9 & 5 & 0,556 \\
8 & 4045284328 & 11 & 8 & 0,727 \\
9 & 4120803494 & 12 & 7 & 0,583 \\
10 & 4169242034 & 11 & 9 & 0,818 \\
11 & 4176635852 & 12 & 8 & 0,667 \\
12 & 4180400502 & 12 & 3 & 0,250 \\
13 & 4180501293 & 12 & 6 & 0,500 \\
14 & 4180661297 & 12 & 9 & 0,750 \\
15 & 4180774522 & 12 & 11 & 0,917 \\
16 & 4182321236 & 11 & 3 & 0,273 \\
17 & 4182464473 & 12 & 7 & 0,583 \\
18 & 4183148379 & 12 & 2 & 0,167 \\
19 & 4183221044 & 12 & 10 & 0,833 \\
20 & 4183243194 & 11 & 7 & 0,636 \\
21 & 4183381038 & 12 & 7 & 0,583
\end{tabular}




\begin{tabular}{llccl}
22 & 4183410560 & 8 & 7 & 0,875 \\
23 & 4183567837 & 12 & 7 & 0,583 \\
24 & 4183724232 & 12 & 3 & 0,250 \\
25 & 4184414970 & 12 & 8 & 0,667 \\
26 & 4189196757 & 12 & 8 & 0,667 \\
27 & 4189212793 & 12 & 8 & 0,667 \\
28 & 4189505287 & 12 & 8 & 0,667 \\
29 & 4190438222 & 12 & 8 & 0,667 \\
30 & 4190443292 & 12 & 6 & 0,500 \\
31 & 4190674273 & 12 & 3 & 0,250 \\
32 & 4191109741 & 12 & 5 & 0,417 \\
33 & 4191161795 & 12 & 7 & 0,583 \\
34 & 4192648933 & 12 & 10 & 0,583 \\
35 & 4194587579 & 12 & 10 & 0,833 \\
36 & 4194810364 & 12 & 7 & 0,833 \\
37 & 4196685921 & 10 & 11 & 0,700 \\
38 & 4197295502 & 12 & 6 & 0,917 \\
39 & 4197659089 & 12 & 10 & 0,500 \\
40 & 4199905389 & 12 & 5 & 0,833 \\
41 & 4205343276 & 9 & 4 & 0,556 \\
42 & 4208437850 & 12 & 9 & 0,333 \\
43 & 4238997297 & 12 & 6 & 0,750 \\
44 & 4249821341 & 12 & 10 & 0,833 \\
45 & 4258157138 & 12 & 0,500 \\
\hline
\end{tabular}

Fonte: a autora, com base em análise estatística realizada para a pesquisa

Tabela 5: Resumo do agrupamento das empresas pesquisadas, sobre o tema comunicação

\begin{tabular}{ccccc}
\hline & ID_Respondente & Clusters & Soma & Proporção \\
\hline 1 & 3262894152 & Modelo 3 ou 4 & 9 & 0,750 \\
2 & 3306325658 & Modelo 3 ou 4 & 9 & 0,750 \\
3 & 4030360043 & Modelo 3 ou 4 & 9 & 0,750 \\
4 & 4031028530 & Modelo 3 ou 4 & 11 & 0,917 \\
$\mathbf{5}$ & $\mathbf{4 0 3 1 2 8 4 7 7 1}$ & Modelo 1 ou 2 & $\mathbf{2}$ & $\mathbf{0 , 2 8 6}$ \\
6 & 4044593736 & Modelo 3 ou 4 & 7 & 0,583 \\
7 & 4044976811 & Modelo 3 ou 4 & 5 & 0,556 \\
8 & 4045284328 & Modelo 3 ou 4 & 8 & 0,727 \\
9 & 4120803494 & Modelo 3 ou 4 & 7 & 0,583 \\
10 & 4169242034 & Modelo 3 ou 4 & 9 & 0,818 \\
11 & 4176635852 & Modelo 3 ou 4 & 8 & 0,667 \\
$\mathbf{1 2}$ & $\mathbf{4 1 8 0 4 0 0 5 0 2}$ & Modelo 1 ou 2 & $\mathbf{3}$ & $\mathbf{0 , 2 5 0}$ \\
13 & 4180501293 & Modelo 3 ou 4 & 6 & 0,500 \\
14 & 4180661297 & Modelo 3 ou 4 & 9 & 0,750 \\
15 & 4180774522 & Modelo 3 ou 4 & 11 & 0,917 \\
$\mathbf{1 6}$ & $\mathbf{4 1 8 2 3 2 1 2 3 6}$ & Modelo 1 ou 2 & $\mathbf{3}$ & $\mathbf{0 , 2 7 3}$ \\
\hline 17 & 4182464473 & Modelo 3 ou 4 & 7 & 0,583 \\
$\mathbf{1 8}$ & $\mathbf{4 1 8 3 1 4 8 3 7 9}$ & Modelo 1 ou 2 & $\mathbf{2}$ & $\mathbf{0 , 1 6 7}$ \\
\hline 19 & 4183221044 & Modelo 3 ou 4 & 10 & 0,833 \\
\hline
\end{tabular}




\begin{tabular}{ccccc}
20 & 4183243194 & Modelo 3 ou 4 & 7 & 0,636 \\
21 & 4183381038 & Modelo 3 ou 4 & 7 & 0,583 \\
22 & 4183410560 & Modelo 3 ou 4 & 7 & 0,875 \\
23 & 4183567837 & Modelo 3 ou 4 & 7 & 0,583 \\
\hline 24 & $\mathbf{4 1 8 3 7 2 4 2 3 2}$ & Modelo 1 ou 2 & $\mathbf{3}$ & $\mathbf{0 , 2 5 0}$ \\
\hline 25 & 4184414970 & Modelo 3 ou 4 & 8 & 0,667 \\
26 & 4189196757 & Modelo 3 ou 4 & 8 & 0,667 \\
27 & 4189212793 & Modelo 3 ou 4 & 8 & 0,667 \\
28 & 4189505287 & Modelo 3 ou 4 & 8 & 0,667 \\
29 & 4190438222 & Modelo 3 ou 4 & 8 & 0,667 \\
30 & 4190443292 & Modelo 3 ou 4 & 6 & 0,500 \\
\hline 31 & $\mathbf{4 1 9 0 6 7 4 2 7 3}$ & Modelo 1 ou 2 & $\mathbf{3}$ & $\mathbf{0 , 2 5 0}$ \\
$\mathbf{3 2}$ & $\mathbf{4 1 9 1 1 0 9 7 4 1}$ & Modelo 1 ou 2 & $\mathbf{5}$ & $\mathbf{0 , 4 1 7}$ \\
\hline 33 & 4191161795 & Modelo 3 ou 4 & 7 & 0,583 \\
34 & 4192648933 & Modelo 3 ou 4 & 7 & 0,583 \\
35 & 4194587579 & Modelo 3 ou 4 & 10 & 0,833 \\
36 & 4194810364 & Modelo 3 ou 4 & 10 & 0,833 \\
37 & 4196685921 & Modelo 3 ou 4 & 7 & 0,700 \\
38 & 4197295502 & Modelo 3 ou 4 & 11 & 0,917 \\
39 & 4197659089 & Modelo 3 ou 4 & 6 & 0,500 \\
40 & 4199905389 & Modelo 3 ou 4 & 10 & 0,833 \\
41 & 4205343276 & Modelo 3 ou 4 & 5 & 0,556 \\
\hline $\mathbf{4 2}$ & $\mathbf{4 2 0 8 4 3 7 8 5 0}$ & Modelo 1 ou 2 & $\mathbf{4}$ & $\mathbf{0 , 3 3 3}$ \\
43 & 4238997297 & Modelo 3 ou 4 & 9 & 0,750 \\
44 & 4249821341 & Modelo 3 ou 4 & 10 & 0,833 \\
45 & 4258157138 & Modelo 3 ou 4 & 6 & 0,500 \\
\hline
\end{tabular}

Fonte: a autora, com base em análise estatística realizada para a pesquisa 